$\gamma \quad$ basg.

\title{
WASTE MANAGEMENT PLAN
}

for the

ORNL/RAP/SUb--87/99053/10

DE92 008213

Oak Ridge National Laboratory

Remedial Investigation/

Feasibility Study

April 1988

\section{U. S. Department of Energy Oak Ridge Operations Office}

Bechtel National, Inc. CH2M Hill - EDGe - PEER for

Oak Ridge National Laboratory Operated by

Martin Marietta Energy Systems, Inc. DISTHIEUTION OF THIS DOCUMEEVT IOS UNLIMATEO 
This roport has been reproduced directly from the best avallable copy.

Avaliable to DOE and DOE contractors trom the Office of Scientfic and Technt cal information, P.O. Box 62, Oak Pildoe, TN 37831; prices avallable from (615) 576-8401, FTS 626-8401.

Avaltable to the public from the National Technical Imiormation Service, U.S. Department of Commerce, 5285 Port Royal Rd., Springfield, VA 22161.

NTIS price codes-Printed Copy: A, 10 Microfiche A01

This report was prepared as an eccount of work sponsored by an agency of the United States Government. Nelther the United States Government nor any agency thereof, nor any of their employees, makes any warranty, express or implied, or assumes any legal liability or responsibility for the accuracy, completeness, or usetulness of any information, apparatus, product, of process disclosed, or represents that its use would not intringe privately owned rights. Feference hereth to any specific commercial product, process, or service by trade name, trademark, manufacturer, or otherwise, does not necesearity constitute or imply its endorsement, recommendation, or favoring by the United States Government or any agency thereof. The views and opinions of authors expressed herein do not necessarily state or reflect those of the United States Government or any 8 s. ncy thereot. 


\author{
WASTE MANAGEMENT PLAN \\ FOR THE \\ OAK RIDGE NATIONAL LABORATORY \\ REMEDIAL INVESTIGATION/FEASIBILITY STUDY
}

APRIL 1988

\author{
Report Prepared by \\ Berhtel National. Inc. \\ P. O. Box 350 \\ Oak Ridge, Tennessee 37830 \\ under \\ Subcontract 30B-99053C \\ for \\ Oak Ridge National Laboratory \\ Oak Ridge, Tennessee 37831 \\ Operated by \\ MARTIN MARIETTA ENERGY SYSTEMS, INC. \\ for the \\ U.S. DEPARTMENT OF ENERGY \\ under Contract DE-AC05-840R21400
}

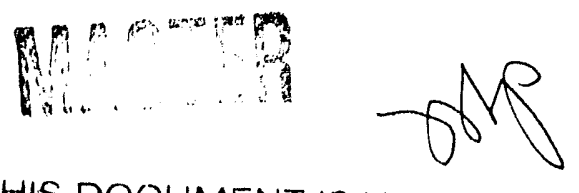


1.0 Introduction $1-1$

2 .0 Responsibilities and Authorities 2-1

2.1 Energy Systems 2-1

2.1.1 RI/FS Subcontract Project Manager 2-1

2. I. 2 Technical Coordinator

2.1.3 Field Coordinator 2-3

2.2 BNI Team

2.2.1 Program Manager $2-3$

2.2.2 Environmental, Safety and Health Manager $2-3$

2.2.3 Deputy Program Manager 2-4

2.2.4 Field Services and Support Manager 2-5

2.2.5 Field Health and Safety Supervisor 2-5

2.2.6 Health and Safety Technicians 2-5

2.2.7 Project-Wide Responsibility 2-6

3.0 Training $3-1$

4.0 Laws, Regulations, and Procedures 4-1

4.]. Laws $4-1$

4.2 Regulations $4-2$

4.3 ORNL Procedures $4-4$

4.4 RI/FS Project Procedures $4-4$

5.0 Waste Classification $5-1$

5.1 Radiological Waste Constituents $5-1$

5.2 Chemical Waste Constituents $5-2$

5.3 Waste Generation $5-3$

5.4 Waste Volumes $5-3$

6.0 Waste Handling $6-1$

6.1 Solid Waste Definitions 6-1

6.1.1 Low-Level Radioactive Waste 6-1

6.1 .2 I.LW Exceptions 6-1

6.1 .3 TRU Wastes $6-7$

6.1 .4 Hazardous/Mixed/TSCA Wastes 6-7

6.1 .5 Conventional Waste 6-7

6.2 Liquid Waste Definitions $6-7$

6.2.1 Radioactive Liquid Waste 6-12

6.2.2 Hazardous/Mixed/TSCA Liquid Waste 6-12

6.2.3 Conventional Liquid Waste 6-12

6.3 Collection of Waste Materials $6-12$

6.3 .1 Training 6-13

6.3.2 Minimization 6-13

6.3.3 Containment 6-16

6.3.4 Health and Safety Monitoring 6-17

6.4 Characterization and Segregation $6-17$

6.4.1 Characterization and segregation of soils 6-18

6.4.2 Characterization and Segregation of Liquid 6-24

6.4.3 Characterization and segregation of 6-25 
6.5 Solid Waste Packaging and Certification

$6-25$

6.5.1 Category 1: Low-Range Compactible LLW

$6-26$

6.5.

Category

$6-26$

$6 \cdot 5 \cdot 3$

Category

$2:$

Low-Range Noncompactible LLW

$6-27$

6.5 .4

Category

High-Range LLW

6.5 .5

Category

4: High-Range LLW

(Special case)

$6-27$

6.5 .6

Category

U-235 Waste

$6-28$

6.5 .7

Category

Suspect LLW

$6-28$

6.5 .8

Category

Radioactive Asbestos Waste

$6-29$

6.5 .9

Category 9 :

Contact-Handled TRU Waste

6.5.10 Category 10:

Remote-Handled TRU Waste

Characteristic Hazardous Waste

Listed Hazardous Waste

6.5 .11 Category $11:$

Characteristic and Listed

Hazardous waste

6.5.13 Category 13:

LLW Mixed Characteristic Waste

LLW Mixed Liquid Waste

I.LW Mixed Characteristic and

Listed Waste

6.5.15 Category 15:

TRU Mixed Waste

6.5.16 Category 16:

LLW Exception Mixed Character-

istic Waste

6.5.18 Category 18:

LLW Exception Mixed Listed

Waste

6.5.19 Category 19:

LLW Exception Mixed Character-

$6-30$

$6-31$

$6-31$

$6-31$

$6-32$

$6-32$

$6-32$

$6-33$

$6-33$

$6-34$

$6-34$

istic and Listed Waste

6.5.20 Category 20:

TSCA Waste

6.5.21 Category 21:

Radioactive TSCA Waste

6.5.22 Category 22:

Disposable Conventional

Scrap Metal Waste

6.5.24 Category 24:

Recyclable Waste

6.6 Soil Handing Criteria

6.6.1 Category I Soils

6.6.2 Category II Soils

6.6.3 Category III Soils

6.7 Liquid Waste Packaging and Certification

6.7.1 Category 1: PWTP waste

6.7 .2 Category 2:

6.7.3 Category 3:

Low-Level Liquid Waste

6.7.4 Category 4:

TRU Liquid Waste

Characteristic Hazardous

Liquid Waste

6.7.5 Category 5: Listed Hazardous Liquid

Waste

6.7.6 Category 6:

Characteristic and Listed

6.7.7 Category 7: Mixed PWTP Waste

6.7 .8 Category $8:$

6.7.9 Category 9 :

6.7.10 Category 10:

Mixed Low-Level Liquid Waste

Mixed TRU Liquid Waste

TSCA Liquid Waste

Radioactive TSCA Liquid Waste

$6-34$

$6-35$

$6-35$

$6-36$

$6-36$

$6-37$

$6-37$

$6-37$

$6-37$

$6-38$

$6-38$

$6-38$

$6-39$

$6-39$

$6-39$

$6-39$

$6-40$

$6-40$

$6-40$

$6-40$

$6-40$

6.7.11 Category 11:

$6-41$ 
TABLE OF CONTENTS

(Cont inued)

Page

6.7.12 Category 12: Uncontaminated Liquid Waste

$6-41$

6.7.13 Category 13: Sanitary Liquid Waste

6.7.14 Category 14: Recyclable Oil

$6-41$

$6-42$

6.8 Waste Package Transportation

$6-42$

6.8 .1 Solid Wastes

$6-43$

6.8.2 Liquid Waste

$6-45$

7.0 Records

$7-1$

References

R-I

Attachment $\mathrm{A}$ :

Characteristics of a Hazardous Waste

A- 1

Attachment B:

Lists of Hazardous Wastes

$B-1$

At tachment C:

Health, Safety, and Environmental

Protection Procedure for Excavating

C- 1

operation 


\section{LIST OF FIGURES}

Figure

$2-1$

$6-1$

$6-2$

Title

Page

Energy Systems and BNI Team Interfaces and

$2-2$ Organization for Waste Management Program

$6-6$

Solid Waste Categories Segregation Chart

$6-11$ 
Table

4-1 ORNL Environmental Protection Manual

$4-5$ Waste Management Procedures

$5-1$

Summary of Available Data on Contaminant Types and Inventories of Wastes by Waste Area Grouping, ORNL

$5-2$

Summary of Known Hazardous Chemicals/Compounds

$5-10$ Currentiy Used and/or Treated at ORNL

$6-1$

Categories of Solid Waste at Oak Ridge

$6-2$ National Laboratory

$6-2$

Guides for Unrestricted Release

$6-8$

$6-3$

Categories of Liquid Waste at Oak Ridge

$6-9$ National Laboratory

Health-Based Soil Concentration Criteria

$6-20$

$A-1$

Maximum Concentration of Contaminants for Characteristic of EP Toxicity

A-5

B-1

Hazardous Wastes from Nonspecific Sources

$B-3$

B-2

Hazardous Wastes from Specific sources

B-4

B-3

Acute Hazardous Discarded Commercial Products

$\mathrm{B}-7$

Off-specification Species, Container Residues, and Spill Residues Thereof

B-4 Discarded Commercial Chemical products, off-specification species, Container Residues, and Spill Residues Thereof 


\section{ACRONYMS}

\begin{tabular}{|c|c|}
\hline ALARA & As Low as Reasonably Achievable \\
\hline BNI & Bechtel National, Inc. \\
\hline CAS & Chemical Abstract Service \\
\hline CEQ & Council on Environmental Quality \\
\hline CERCLA & $\begin{array}{l}\text { Comprehensive Environmental Response, Compensation, and } \\
\text { Liability Act }\end{array}$ \\
\hline CFR & Code of Federal Regulations \\
\hline CG & Concentration Guide \\
\hline CSL & Close Support Laboratory \\
\hline DOE & Department of Energy \\
\hline DOL & Department of Isabor \\
\hline DOT & Department of Transportation \\
\hline DP & Deputy Program \\
\hline EMC & Environmental Monitoring and Compliance \\
\hline EP & Extraction Procedure \\
\hline EPA & Enviconmental Protection Agency \\
\hline EPM & Environmental Protection Manual \\
\hline ES\&H & Environmental, Safety and Health \\
\hline FHS & Field Health and safety \\
\hline FSS & Field services and support \\
\hline GC & Gas Chromatography \\
\hline GCO & Generator Certification officer \\
\hline GM & Geiger Muller \\
\hline H\&S & Health and Safety \\
\hline HEPA & High Efficiency Particulate Air \\
\hline HF & Hydrofracture \\
\hline HF IR & High Flux Isotope Reactor \\
\hline HRE & Homogeneous Reactor Experiment \\
\hline HWP & Hazardous Work Permit \\
\hline LLLW & Low-Level Liquid Waste \\
\hline LI,W & Low-Level Waste \\
\hline NACE & National Association of Corrosion Engineers \\
\hline NEPA & National Enviconmental Policy Act \\
\hline NHE & New Hydrofracture Facility \\
\hline
\end{tabular}


ACRONYMS (Continued)

$\begin{array}{ll}\text { NRC } & \text { Nuclear Regulatory Commission } \\ \text { OHF } & \text { Old Hydrofracture Facility } \\ \text { ORNL } & \text { Oak Ridge National Laboratory } \\ \text { ORR } & \text { Oak Ridge Reservation } \\ \text { P\&E } & \text { Plant and Equipment } \\ \text { PCB } & \text { Polychlorinated Biphenyl } \\ \text { PPE } & \text { Personal Protective Equipment } \\ \text { PWTP } & \text { Process Waste Treatment Plant } \\ \text { RCRA } & \text { Resource Conservation and Recovery Act } \\ \text { RFA } & \text { RCRA Facilities Assessment } \\ \text { RFI } & \text { RCRA Facility Investigation } \\ \text { RI } & \text { Remedial Investigation } \\ \text { RI/FS } & \text { Remedial Investigation/Feasibility study } \\ \text { SWMU } & \text { Solid Waste Management Unit } \\ \text { SWSA } & \text { Solid Waste storage Area } \\ \text { TDHE } & \text { Tennessee Department of Health and Environment } \\ \text { TRU } & \text { Transuranic } \\ \text { TSCA } & \text { Toxic Substances Control Act } \\ \text { WAG } & \text { Waste Area Grouping } \\ \text { WEAF } & \text { Waste Examination Assay Facility } \\ \text { WOC } & \text { White Oak Creek } \\ \text { WOL } & \text { White Oak Lake }\end{array}$




\section{ABBREVIATIONS}

\begin{tabular}{|c|c|}
\hline $\mathrm{Bq} / \mathrm{g}$ & Becquerel per gram \\
\hline $\mathrm{Bq} / \mathrm{kg}$ & Becquerel per kilogram \\
\hline $\mathrm{Bq} / \mathrm{L}$ & Becquerel per liter \\
\hline $\mathrm{Bq} / 100 \mathrm{~cm}^{2}$ & Becquerel per one hundred square centimeters \\
\hline $\mathrm{dpm} / 100 \mathrm{~cm}^{2}$ & $\begin{array}{l}\text { Disintegrations per minute per one hundred } \\
\text { square centimeters }\end{array}$ \\
\hline g & gram \\
\hline $\mathrm{mrad} / \mathrm{h}$ & milliroentgen absorbed dose per hour \\
\hline $\mathrm{mrem} / \mathrm{h}$ & milliroentgen equivalent man per hour \\
\hline $\mathrm{mSv} / \mathrm{h}$ & millisievert per hour \\
\hline $\mathrm{nCi} / \mathrm{g}$ & nanocurie per gram \\
\hline $\mathrm{nCi} / \mathrm{mL}$ & nanocurie per milliliter \\
\hline $\mathrm{rem} / \mathrm{h}$ & roentgen equivalent man per hour \\
\hline $\mathrm{Sv} / \mathrm{h}$ & sievert per hour \\
\hline $\mathrm{uCi} / \mathrm{g}$ & microcurie per gram \\
\hline $\mathrm{uCi} / \mathrm{L}$ & microcurie per liter \\
\hline $\mathrm{uCi} / \mathrm{mL}$ & microcurie per milliliter \\
\hline uGy/h & microgray per hour. \\
\hline
\end{tabular}




\subsection{INTRODUCTION}

It is the policy of Bechtel National. Inc. (BNI) and its subcontractors to minimize the generation of waste. When waste is generated, Remedial Investigation/Feasibility study (RI/FS) project field activities will be conducted in accordance with the RI/FS waste management program, an integrated effort comprising Martin Marietta Energy Systems (Energy Systems) policies and procedures, this Waste Management Plan, and RI/FS project procedures.

During the course of the RI/FS project, waste materials will be generated as a result of field investigation activities. As a guidance document for the waste management program, the waste Management Plan establishes those standards, criteria, waste handing and packaging requirements, and RI/FS project interfaces necessary to ensure proper collection, identification, segregation, classification, packaging, and certification of waste materials. The guidelines established in the Waste Management plan will help ensure RI/FS project compliance with federal, state, U.S. Department of Energy (DOE), Oak Ridge National Laboratory (ORNL), and Energy systems' regulations, policies, and procedures.

In accordance with the requirements of the RI/FS project Quality Assurance Plan, the Waste Management Plan establishes clear lines of responsibility and authority, documentation requirements, and operational guidance for the collection, identification, segregation, classification, packaging, certification, and storage/disposal of wastes. These subjects are discussed in the subsequent sections of this document.

During the course of RI/FS activities, changes in waste management procedures may occur due to implementation of DOE Order 5820.2, through recommendations made by the Low Level Waste Disposal Development and Demonstration Program. Changes may occur in waste classification and packaging requirements, both of which may also 
result in increased costs. This plan will be amended appropriately. as necessary to reflect any future changes in waste management practices. 


\subsection{RESPONSIBILITIES AND AUTHORITIES}

Ultimate responsibility for waste management at ORNL resides with Energy systems. For the ORNL RI/FS project, this responsibility has been extended to the BNI Team, which will exercise its responsibilities and authorities through interface with, and guidance from. Energy systems. Specifically. BNI shall be responsible for the collection, identificatiun, segregation, classification, packaging, and certification of wastes generated by RI/FS project field activities. Both BNI and Energy systems will be responsible for pickup and delivery of packaged wastes to treatment, storage, or disposal locations.

The relatiorships of key Energy Systems and BNI positions as they relate to waste management, are depicted in Figure 2-1. The waste management responsibilities and authorities for these positions are defined in the following subsections. Comprehensive descriptions of the overall project organization, responsibilities, and authorities are contained in the ORNL RI/FS Project Management Plan (BNI, 1987a).

\subsection{ENERGY SYSTEMS}

\subsubsection{RI/FS Subcontract Project Manager}

The ORNL RI/FS Subcontract Project Manager (Project Manager) has prime responsibility and authority for the technical, financial, and administrative performance of the overall RI/FS Program, including that of waste management. The Project Manager is also responsible for ensuring that waste management program plans, procedures, and field activities implement and comply with applicable, relevant, and appropriate federal, state, DOE, and ORNL requirements.

\section{1 .2 Technical Coordinator}

The Technical Coordinator reports directly to the Project Manager and is the primary contact between BNI management and the ORNL technical divisions (e.g., Environmental Sciences, Energy, 


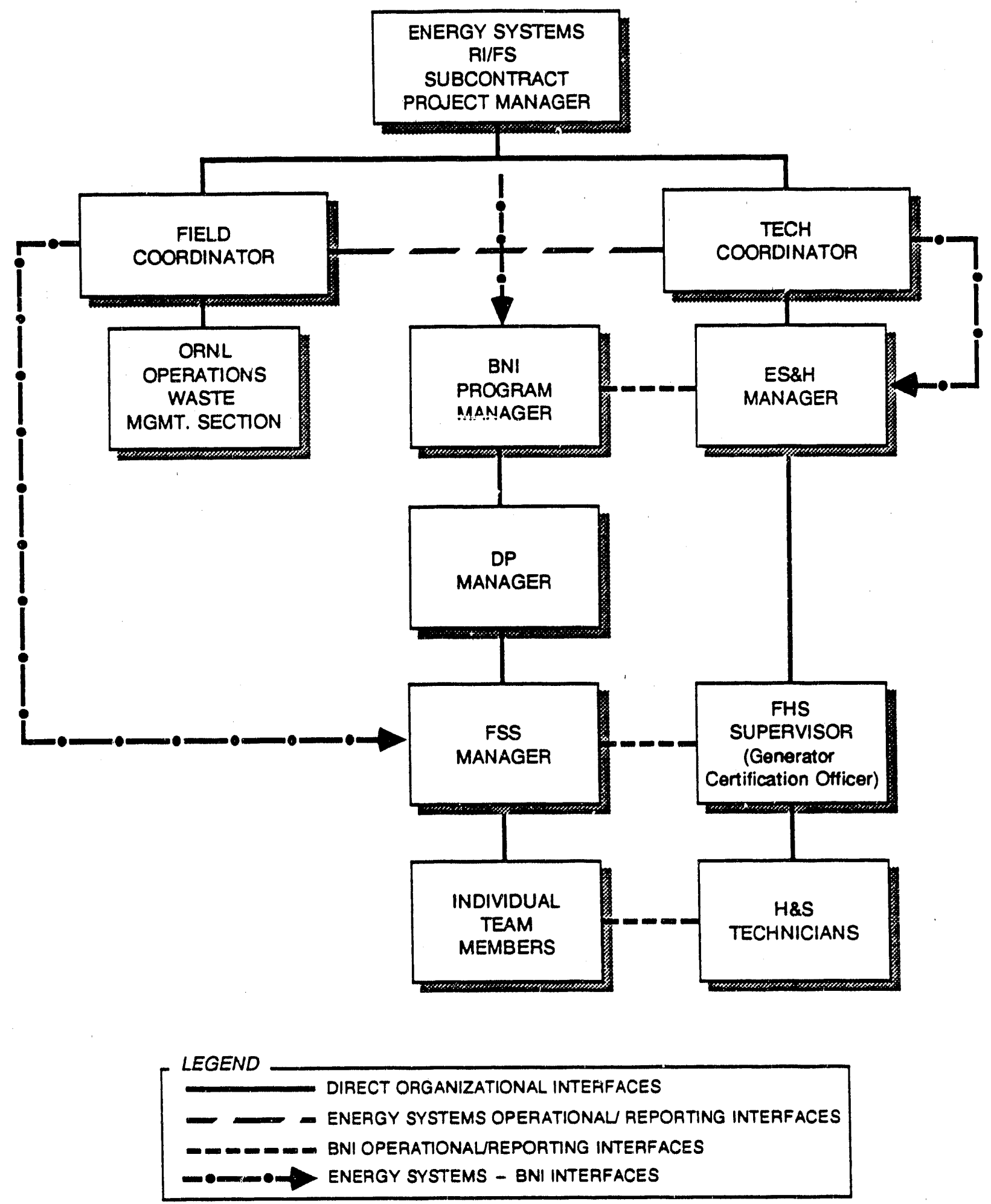

FIGURE $2-1$

ENERGY SYSTEMS AND BNI TEAM INTERFACES AND ORGANIZATION FOR WASTE MANAGEMENT PROGRAM $2-2$ 
Analytical Chemistry, Chemical Technology, Nuclear and Chemical Waste programs). The Technical Coordinator provides programmatic guidance to the BNI Fnvironmental, Safety and Health (ES\&H) Manager for waste management matters.

\subsubsection{Field Coordinator}

The Field Coordinator reports directly to the Project Manager and is the primary contact between BNI's field operations and various ORNL service and support organizations (e.g.. Laboratory protection. Plant and Equipment, Environmental Compliance and Health Protection, Project and Construction Engineering). The Field coordinator provides the necessary interface between BNI Field services and Support (FSS) Manager and ORNL Waste operations. The Field Coordinator will audit BNI field operations for compliance with applicable waste management procedures, policies, permits, regulations, statutes, and laws. The Field coordinator's authorities include the right to stop work.

\subsection{BNI TEAM}

\section{2 .1 Program Manager}

The Program Manager is the senior BNI manager for the RI/FS project. The Program Manager oversees the technical ar.d programmatic activities of the waste management program, making certain that it satisfies Energy systems' and RI/FS project procedural requirements. When changes or modifications to the Waste Management Plan and/or applicable project procedures are dictated, the Program Manager interfaces with the Energy systems Project Manager to verify concurrence.

\subsubsection{Environmental, Safety and Health Manager}

In waste management matters, the ES\&H Manager is directly responsible to the Program Manager. This responsibility includes 
the development and technical overview of the waste management program.

The ES\&H Manager is responsible for interfacing with the Energy systems Technical and Field Coordinators to ensure continuing applicability of the Waste Management Plan and applicable project procedures. This responsibility includes notifying the program Manager of the need for changes to the Waste Management Plan and/or procedures and, with his concurrence, implementing the changes.

The ES\&H Manager is also responsible for the following:

- Training of personnel who collect, identify, segregate, classify, package, and transport waste materials (in accordance with Energy Systems and RI/FS project procedures, and applicable federal, state, and DOE requirements)

- Auditing RI/FS project field activities for compliance with procedural requirements

- Timely and effective interface with Energy systems Technical and Field Coordinators regarding waste management policies and practices

The ES\&H Manager has the authority to halt any RI/FS project activity determined to be in noncompliance with waste management program policies, plans, or procedures.

\subsubsection{Deputy Program Manager}

The Deputy Program (DP) Manager reports directly to the Program Manager, and, when the Program Manager is absent or so designates, functions as acting Program Manager. The DP Manager is responsible for overall coordination and support of RI/FS project field activities. As such, the DP Manager is specifically responsible for coordination of RI/FS project field waste management activities. assuring that they comply with the provisions of the waste Management Plan and its implementing procedures. 


\subsubsection{Field Services and Support Manager}

The FSS Manager reports to the DP Manager and is directly responsible for directing and supporting RI/FS project field activities and ensuring field compliance with RI/FS project waste management procedures. The FSS Manager is also responsible for interfacing with the Energy Systems Field Coordinator for logistical support to the waste management program.

\subsubsection{Field Health and Safety supervisor}

The Field Health and Safety (FHS) supervisor reports directly to the ES\&H Manager and is responsible for ensuring that waste collection. identification, segregation, classification, packaging, certification, and transportation activities are conducted in compliance with RI/FS project procedures. The FHS supervisor is responsible for certification of waste packages in accordance with ORNL procedures, and is designated the Generator certification officer (GCO). The FHS supervisor works with the Fss Manager, or designee, to ensure timely and effective execution of these responsibilities.

In the FSS Manager's absence, the FHS Supervisor has authority to interface directly with the Energy systems Field Coordinator regarding disposition of waste materials. The FHs supervisor also has the authority to halt any RI/FS project field activity determined to be in noncompliance with applicable RI/Fs project plans and procedures.

\subsubsection{Health and Safety Technicians}

Health and Safety (H\&S) Technicians report directly to the FHS supervisor and are responsible for surveying, sampling, and measuring waste materials for the purposes of segregation and classification. H\&S Technicians are also responsible for completing appropriate portions of forms and for posting and placarding in accordance with RI/FS project procedures. 
H\&S Technicians are responsible to the FHS supervisor for auditing waste management program field activities to ensure proper packaging and handing of waste materials. H\&S Technicians have authority to halt work whenever a RI/FS field activity is determined to be in noncompliance with applicable plans and procedures.

\subsubsection{Project-Wide Responsibility}

Each individual assigned to the RI/FS project is responsible for adherence to the Waste Management Plan and its implementing project procedures. 


\subsection{TRAINING}

Personnel responsible for classifying and packaging waste materials will be provided specific waste management training. As a minimum, this training will include the following:

- Waste classification criteria

- Classification techniques and requirements

- Packaging requirements

- Waste minimization

BNI will provide training on waste segregation, classification, and packaging. All personnel who package and/or certify waste must attend, and successfully complete, the Energy systems' training course, "Segregation of Hazardous Waste from Solid Low-Level Waste -- Inspector Training program." Personnel responsible for packaging and/or certification of transuranic (TRU) waste must attend, and successfully complete, Energy systems' "TRU Waste Certification Training."

In addition to the waste classification training provided by Energy Systems, BNI will provide training for techniques and criteria as appropriate for project-specific work conducted at specific Waste Area Groupings (WAGs). BNI training requirements are contained in Project Procedure 1404, "Waste Management Training."

BNI will document the successful completion of all Energy systems and BNI training courses. BNI will provide Energy systems with names and appropriate identification of individuals successfully completing each course. Incividuals failing to successfully complete required training will not be permitted to participate in waste management activities. 


\subsection{LAWS, REGULATIONS, AND PROCEDURES}

Waste management operations at ORNL are conducted in accordance with applicable federal and state laws and regulations and DOE orders. Compliance with applicable provisions of these laws, regulations, and orders is ensured through the implementation of a series of oRNL operating procedures.

The Waste Management Plan provides the guidance necessary to ensure that RI/FS project field activities comply with these laws, regulations, orders, and procedures. The laws, regulations, orders, and procedures applicable to RI/FS field activities are listed in the following subsections.

\section{1 LAWS}

The applicable laws governing waste management and related activities at the ORNL include the following:

- The Atomic Energy Act of 1954, Public Law 83-703, as currently amended

- The National Environmental Policy Act (NEPA) of 1969, Public Law 91-190, as currently amended

- The Resource Conservation and Recovery Act (RCRA) of 1976 , Public Law 94-580, as currently amended

- The Comprehensive Environmental Response, Compensation, and Liability Act (CERCLA) of 1980. Pubilic Law 96-510, as currently amended

- The Toxic Substances Control Act (TSCA) of 1976, Public Law $94-469$, as currently amended

- The Water Pollution Control Act (Clean Water Act) of 1972 , Public Law 92-500, ds currently amended

- The Safe Drinking water Act of 1974, Public Law 93-523, as curcently amended

- The Air Pollution Control Act (Clean Air Act) of 1955. Public Law 84-159, as currently amended 
- The occupational Safety and Health Act of 1970, Public Law 91-596, as currently amended

- The Transportation Safety Act of 1974, Public Law 93-633, as curcently amended

- The state of Tennessee Water Quality Control Act, 70TC3, as currently amended

- The state of Tennessee Solid Waste Disposal Act, 53TC43, as currently amended

- The state of Tennessee Hazardous Waste Management Act, 53 TC63, as currently amended

\subsection{REGULATIONS}

Numerous federal and state regulations, including DOE Orders, derive their authority from, and provide standards for, regulation of provisions contained in the foregoing laws. Regulations relevant to various aspects of waste management at ORNL include the following:

- DOE Order 5440.1B, "Implementation of the National Environmental Policy Act"

- DOE Order 5480.1A, "Environmental Protection, Safety, and Health Protection Programs for DOE Operations"

- DOE Order 5480.10, "Contractor Industrial Hygiene"

- DOE Order 5482.1A, "Environmental Protection, Safety, and Health Protection Appraisal Program"

- DOE Order 5483.1. "Occupational Safety and Health Program for Government-Owned Contractor-operated Facilities"

- DOE Order 5484.1. "Environmental Protection, Safety, and Health Protection Information Reporting Requirements"

- DOE Order 5500.2, "Emergency Planning, Preparedness, and Responses for Operations"

- DOE-ORO Notice 5500.2A. "Procedures for the Classification, Notification, and Reporting of Emergency and Nonroutine Events"

- DOE Order 5820.2, "Radioactive Waste Management" 
- Nuclear Regulatory Commission (NRC) Regulation 10 CFR 61, "Licensing Requirements for Land Disposal of Radioactive Waste"

- DOE Regulation 10 CFR 1021, "Compliance with the National Environmental Policy Act"

- U.S. Environmental Protection Agency (EPA) Regulation 40 CFR 61. "National Emission Standards for Hazardous Air Pollutants"

- EPA Regulation 40 CFR 222, "National Pollutant Discharge Elimination System"

- EPA Regulation 40 CFR 136, "Regulations on Test Procedures for the Analysis of Pollutants"

- EPA Regulation 40 CFR 14I, "National Primary Drinking Water Regulations"

- EPA Regulation 40 CFR 142, "National Primary Drinking Water Regulations Implementation"

- EPA Regulation 40 CFR 143, "National Secondary Drinking Water Regulations"

- EPA Regulation 40 CFR 190, "Environmental Radiation Protection Standards for Nuclear Power Operation"

- EPA Regulation 40 CFR 191. "Environmental Radiation Protection Standards for Management and Disposal of spent Nuclear Fuel, High-Level, and Transuranic Radioactive Wastes"

- EPA Regulations, Title 40, "Protection of Environment," Subchapter I, "Solid Waste," Parts 240 through 299

- EPA Regulations, Title 40, "Protection of Environment," Subchapter I, "Superfund Programs", Parts 300 through 399

- EPA Regulations, Title 40, "Protection of Environment," Subchapter R, "Toxic Substances Control Act," Parts 700 through 799

- Council on Environtaental Quality (CEQ) Regulations, Title 40. "Protection of Environment," Parts 1500 through 1508 , "Regulations on Implementing National Environmental Policy Act Procedures"

- Department of Labor (DOL) Regulation 29 CFR 1910, "occupational Safety and Health Standards"

- Department of Transportation (DOT) Regulations, Title 49, "Transportation," Subchapter C, "Hazardous Materials Regulations," Parts 171 through 179 
- Tennessee Department of Health and Environment (TDHE) Regulations Chapter 1200-1-11, "Hazardous Waste Management Rules"

- TDHE Regulations Chapter 1200-1-7. "Solid Waste Regulations"

- TDHE Regulations Chapter 1200-4-1, "General Regulations"

- TDHE Regulations Chapter 1200-4-3, "Water Quality Criteria"

- TDHE Regulations Chapter 1200-4-5, "Effluent Limitations and standards"

\section{3 ORNL PROCEDURES}

Applicable ORNL waste management procedures are contained in both the ORNL Health Physics Manual and the ORNL Environmental protection Manual, and include the following:

- ORNL Health Physics Procedure Number 5.1, "regregation and Management of Solid Radiodctive Waste Materials"

- ORNL Health Physics Procedure Number 5.2, "Entry Control of Materials to Contaminated Zones"

- ORNL Health Physics Procedure Number 5.3, "Disposal of Liquid Wastes"

- ORNL Environmental Protection Procedure Numbers EPM-1.0 through EPM-20.0, EPM-22.0, ESH-7, ESH-12, ESH-14, ESH-15, and ESH-19. A complete 1 ist of titles is shown in Table 4-1.

\subsection{RI/FS PROJECT PROCEDURES}

The following RI/FS waste management project procedures are applicable to RI/FS project field activities:

- Project Procedure 1401. "Waste Categorization"

- Project Procedure 1402, "Waste Handing"

- Project Procedure 1403, "Waste Transportation and storage"

- Project Procedure 1404. "Waste Management Training"

- Project Procedure 1405. "Waste Management Records" 
TABLE $\quad 4-1$

ORNL ENVIRONMENTAL PROTECTION MANUAL WASTE MANAGEMENT PROCEDURES

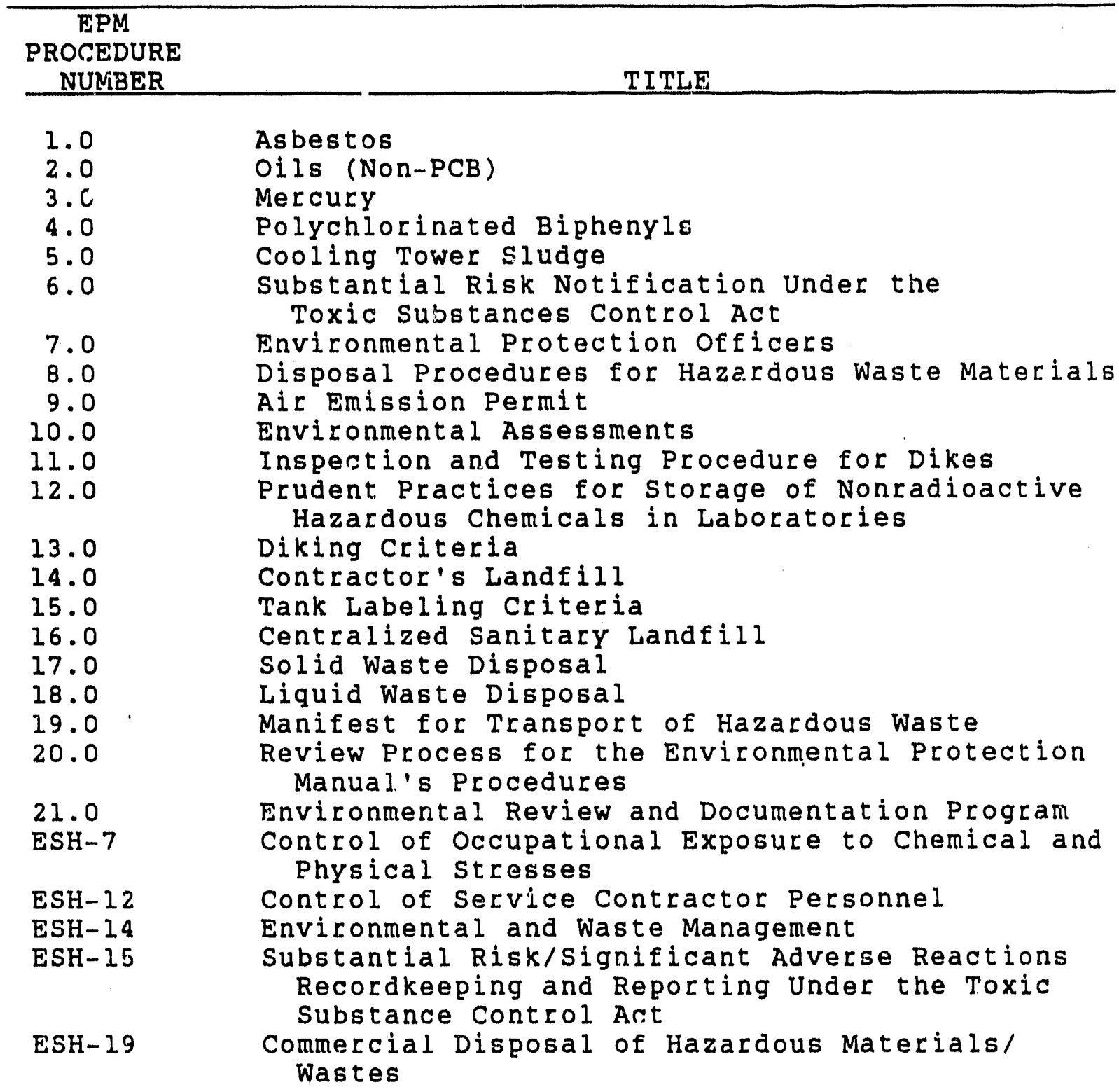




\subsection{WASTE CLASSIFICATION}

RI/FS project field activities will involve remedial investigations (RIs) of known and suspected areas of radiological and/or hazardous chemical contamination. Therefore, it is anticipated that the media under investigation will contain a wide variety of contaminants.

RI activities (i.e.. drilling, trenching, sampling) will result in the generation of contaminated waste materials. These materials may be the media under investigation (i.e., soil, water, biota) and/or the tools and materials used during the investigation. The subsections below 1 ist known waste constituents and anticipated waste sources. The list has been compiled from a review of various documents (Huang et a1.. 1984; ORNL, 1987; Oakes et al., 1987; and Peretz et al., 1986).

\subsection{RADIOLOGICAL WASTE CONSTITUENTS}

Radiological wastes identified at ORNL contain a variety of radionuclides, including:

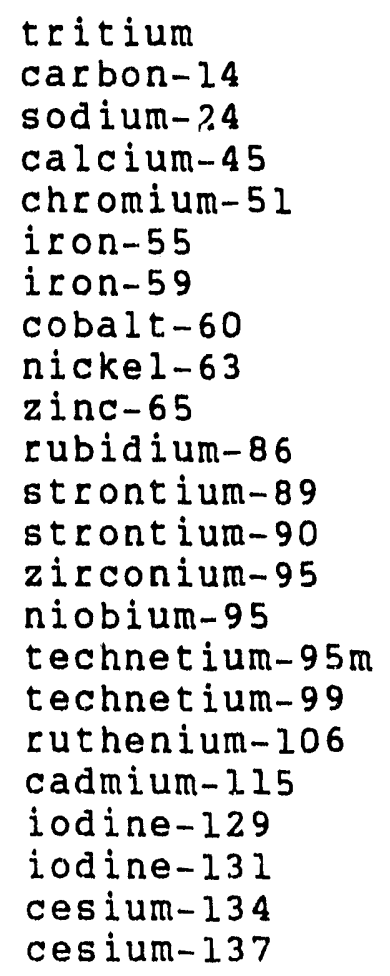

barium- 140

cerium-141

cerium-144

promethium- 147

europium- 152

europium- 154

europium- 155

mercury -203

radium-226

thorium-232

thorium-234

uranium-232

uranium- 233

uranium-23!

uranium-238

neptunium- 237

plut onium-238

plutonium-239

plutonium-240

americium-24I

curium-242

curium-244 
Table 5-1 presents a summary of the principal radionuclides or chemicals and their respective estimated inventories. Summary data are presented for each solid Waste Management Unit (SWMU) within each WAG.

\subsection{CHEMICAL WASTE CONSTITUENTS}

Information concerning historical hazardous chemical contaminant disposal practices is sparse and incomplete. Identified potential contaminants include the following:

- Materials that are hazardous by virtue of their characteristics, [e.g., ignitable, corrosive, reactive, Extraction Procedure (EP) [oxic]

- Volatile organic compounds (benezene, chloroform, methylene chloride, toluene, xylene, etc.)

- Base neutral and acid extractable organics (anthracene, benzo(a)anthracene, benzo(b)fluoranthene, benzo(G,H, I) perylene, benzo(b) pyrene, butylbenzyl phthalate, chrysene, di-n-butyl phthalate, fluoranthene, ideno( $1,2,3-c d)$ pyrene, phenathrene, pyrene, etc.)

- Metals (barium, cadmium, chromium, lead, and mercury)

- Shock-sensitive compounds (picric acid, nitromethane, phosphorus, hydrogen peroxide, and ammonium nitrate)

- Heat-sensitive compounds (formaldehyde)

- Herbicides, pesticides, sulfates, nitrates, chlorides, polychlorinated biphenyls, asbestos, and miscellaneous laboratory chemicals

In addition to these identified potential contaminants, it is possible that sanitary, pathogenic, and infectious waste materials may also be encountered. Other hazardous substances and compounds that may have been disposed of as a result of past disposal practices are listed in Table 5-2. 


\subsection{WASTE GENERATION}

The waste generation activities anticipated during execution of RI/FS field investigations include the following:

- Drilling and excavation spoils

- Drilling liquids and sludges

- Well development liquids

- Pump test liquids

- Fuel, hydraulic fluids, and coclant leakage from equipment

- Samples returned from the analytical laboratory

- Liquids and materials from decontamination operations

- Contaminated tools and equipment for which the cost of decontamination would exceed the worth of the item

- Contaminated protective apparel (e.g.. gloves, shoe covers, coveralls, etc.)

- Close support laboratory wastes

- Mobile decontamination trailer

- Sanitary wastes

- General refuse

\subsection{WASTE VOLUMES}

Specific waste volumes and contaminant concentration data will depend on the location and type of field activity. Consequently, prediction of waste volumes, contaminant concentrations, and schedules for generation will be provided in the Waste Management Plan section of each hiag-specific RI Plan. 
TABLE 5-1

SUMMARY OF AVAILABLE DATA ON CONTAMINANT TYPES AND INVENTORIES

OF WASTES BY WASTE AREA GROUPING, ORNL

\begin{tabular}{|c|c|c|}
\hline Site & Contaminant & $\begin{array}{c}\text { Inventory (a) } \\
\mathrm{Ci}(\mathrm{kg})\end{array}$ \\
\hline
\end{tabular}

WAG 1: Main Plant Area

1.1 Mercury Contaminated Soil (3503)

1.2 (3592)

$1.3(4501)$

1.4 (4508)

$1.5 a+w$ LLW Lines and Leak Sites

1.6 Contaminated Surfaces did Soil from 1959 Explosion in 31dg. $3019 \mathrm{Cell}$

1.7 Contamination at Base of 3019 Stack

1.8 Graphite Reactor Storage Canal Overflow (3001/3019)

1.9 ORR Decay Tank Rupture Site (3085)

1.10 Storage Pads $(3503,3504)$

1.11 Decommissioned Waste Holding Basin (3512)

1. 12 Waste Holding Basin (3513)

1.13 Equalization Basin (3524)

1. 14 Process Waste Pond (3539)

1. 15 Process Waste Pond (3540)

1.16 Sewage Aeration Pond (East) - (2543;

1.17 West Sewage Pond (2544)

1. 18 Coal Pile Settling Basin (2545)

1.19 LITR Pond (3085F)

1.203517 Filter Pit

1.21 LLH Transfer Line

1.2.2 Isotopes Ductwork/ 3110 Filter House

1.23 Inactive (b) Tanks (W-1)

$W-2$

1.24 Inactive Tanks (WB)
$\mathrm{Hg}$

$\mathrm{Hg}$

$\mathrm{Hg}$

$\mathrm{Hg}$

Sr-90, Cs-137, TRU, (c) $\mathrm{Hz}$

Pu-239

Unidentified

Unidentified

Neutron activation products

U-233, Pu-239

Unidentified

Sr -90

Cs-137

Pu-239

$\mathrm{Sr}-90$

Cs-137

Th, U, TRU(C)

Unidentified

Unidentified

Unidentified

Unidentified

Unidentified

Sr-90, Cs-137

Sr $-90, \mathrm{Cs}-137$

Unidentified

Unidentified

$\mathrm{Sr}-90$

Cs -137

TRU (c)

$\mathrm{Sr}-90$

Cs -137

TRU (c)

$\mathrm{Sr}-90$

Cs -137

TRU(c)
$(<1.0)$

$\left(<1.4 \times 10^{3}\right)$

$(<10)$

Presence unconfirmed Unknown

$<4.7 \times 10^{2}$

Presence unconfirmed

Presence unconfirmed

Presence unconfirmed

$<1.0 \times 10^{-1}$

$<1.0 \times 10^{1}$

$3.0 \times 10^{1}$

$2.0 \times 10^{2}$

5.0

$3.0 \times 10^{1}$

$1.0 \times 10^{2}$

$1.1 \times 10^{1}$

$<1.0 \times 10^{1}$

$<1.0 \times 10^{1}$

$<1.0 \times 10^{1}$

$<1.0 \times 10^{1}$ Unknown

$<20 \times 10^{3}$

Unknown

$<1.0 \times 10^{3}$

Unknown

$9.0 \times 10^{-2}$

$2.0 \times 10^{-2}$

$7.0 \times 10^{-4}$

$1.0 \times 10^{1}$

$1.0 \times 10^{1}$

7.0

$<1.0 \times 10^{2}$

$<1.0 \times 10^{3}$

$<1.1 \times 10^{2}$ 
TABLE 5-1 (Continued)

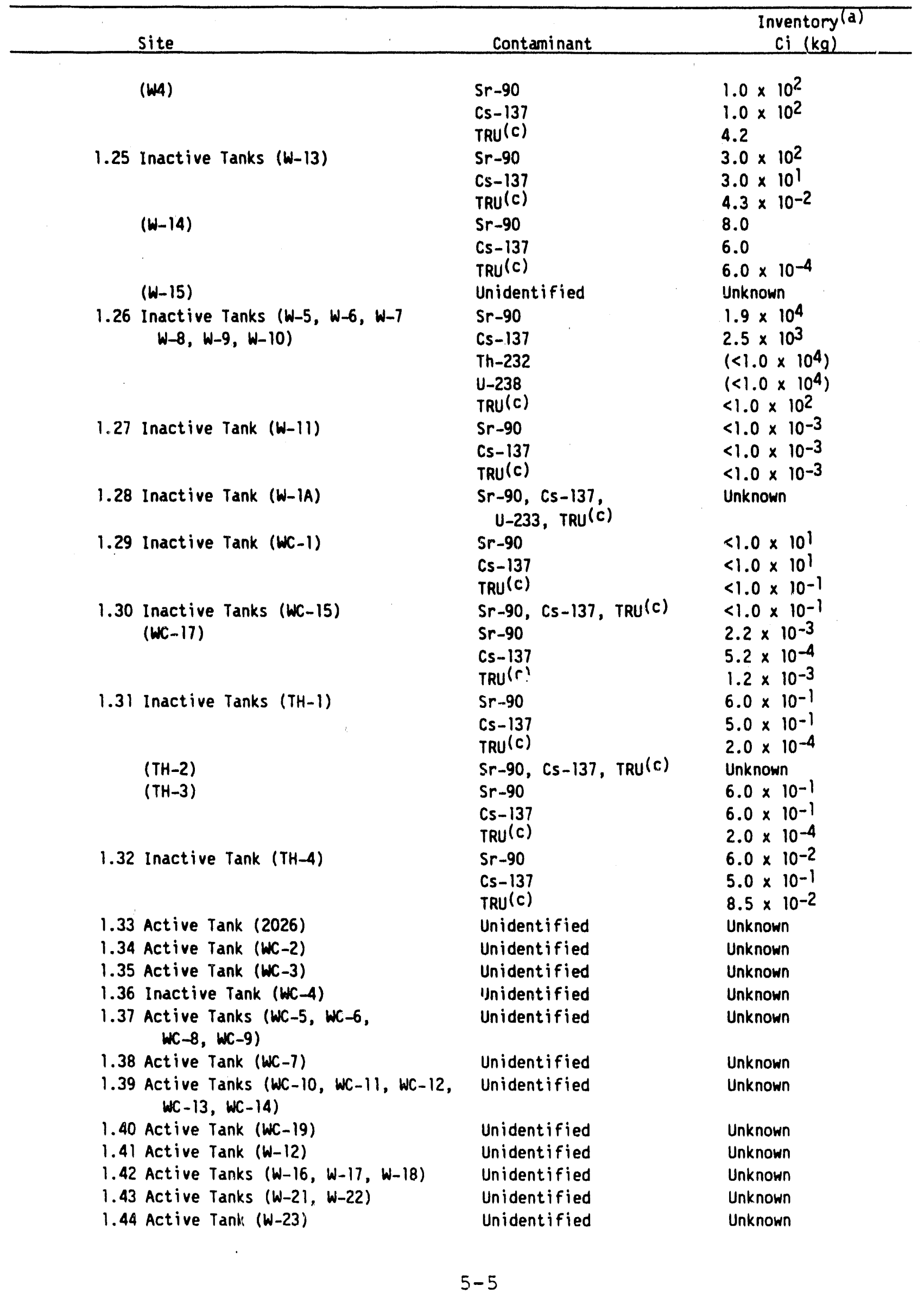


TABLE 5-1 (Continued)

\begin{tabular}{|c|c|c|}
\hline Site & Contaminant & $\begin{array}{l}\text { Inventory (a) } \\
\mathrm{Ci}(\mathrm{kg})\end{array}$ \\
\hline 1.45 Active Tanks $(C-1, C-2)$ & Unidentified & Unknown \\
\hline 1.46 SWSA-1 (2624) & $\begin{array}{l}\text { Sr-90, unidentified } \\
\mathrm{Hz}\end{array}$ & $\begin{array}{l}<4.0 \times 10^{3} \\
\text { Unknown }\end{array}$ \\
\hline 1.47 SWSA-2 (4003) & Unidentified & $\begin{array}{l}\text { Presence unconfirmed } \\
\text { Contents moved } \\
\text { to SWSA-3 } \\
\text { before } 1950\end{array}$ \\
\hline 1.48 LLW Evaporator (2531) & Unidentified & Unknown \\
\hline 1.49 Neutralization Facility (3518) & Unidentified & Unknown \\
\hline 1.50 PCB Storage Area (2018N) & Unidentified & Unknown \\
\hline 1.51 PWTP (3544) & Unidentified & Unknown \\
\hline 1.52 Sewage ireatment Plant (2521) & Unidentified & Unknown \\
\hline 1.53 Bldg. 3000 Septic Tank (3078) & Unidentified & Unknown \\
\hline 1.54 Waste 0 il Storage Tanks (2525) & Unidentified & Unknown \\
\hline
\end{tabular}

WAG 2: WOC and WOL

2.1 WOL and Embayment

Sr-90
Cs-137
Th, U, TRU (c)
Pu.-2.39
Cr
$\mathrm{Pb}$
Sr-90
Cs- 137
$\mathrm{Pu}-239$
$\mathrm{~Hz}$

$2.0 \times 10^{1}$

$5.9 \times 10^{2}$

$<1.0 \times 10^{1}$

$<1.0$ est.

$\left(\leq 2.0 \times 10^{4}\right)$

2.2 WOC and Tributaries

3.1 SWSA $3(1001)$

3.2 Closed Scrap Metal Area (1562)

3.3 Contractors' Landfill (1554)

WAG 4: SWSA 4

4.1 LLW Line

4.2 Pilot Pits 1 and 2

4.3 SWSA-4

$\mathrm{H}-3, \mathrm{Sr}-90$, Unidentified

$<5.6 \times 10^{4}$

$\mathrm{Hz}$

Unidentified

Unknown

Unidentified

Unknown

Unknown

$$
\begin{aligned}
& \text { Unidentified } \\
& \text { None } \\
& \mathrm{H}-3 \text {; CO-60; Sr-90 } \\
& \mathrm{Cs}-137 \text {; Th, U, TRU (c); } \\
& \text { unidentified } \\
& \mathrm{Hz}
\end{aligned}
$$$$
>5.0
$$$$
>1.0 \times 10^{2}
$$$$
>5.0 \times 10^{-1}
$$$$
\text { Unknown }
$$

Unknown

None

$<1.2 \times 10^{5}$

Unknown

WAG 5: SWSA 5

5.1 LLW Lines and Leak Sites

5.2 OHF Pond (7852A)

\author{
Unidentified \\ $\mathrm{Sr}-90$ \\ Cs -137 \\ $\operatorname{TRU}(c)$
}


TABLE 5-1 (Continued)

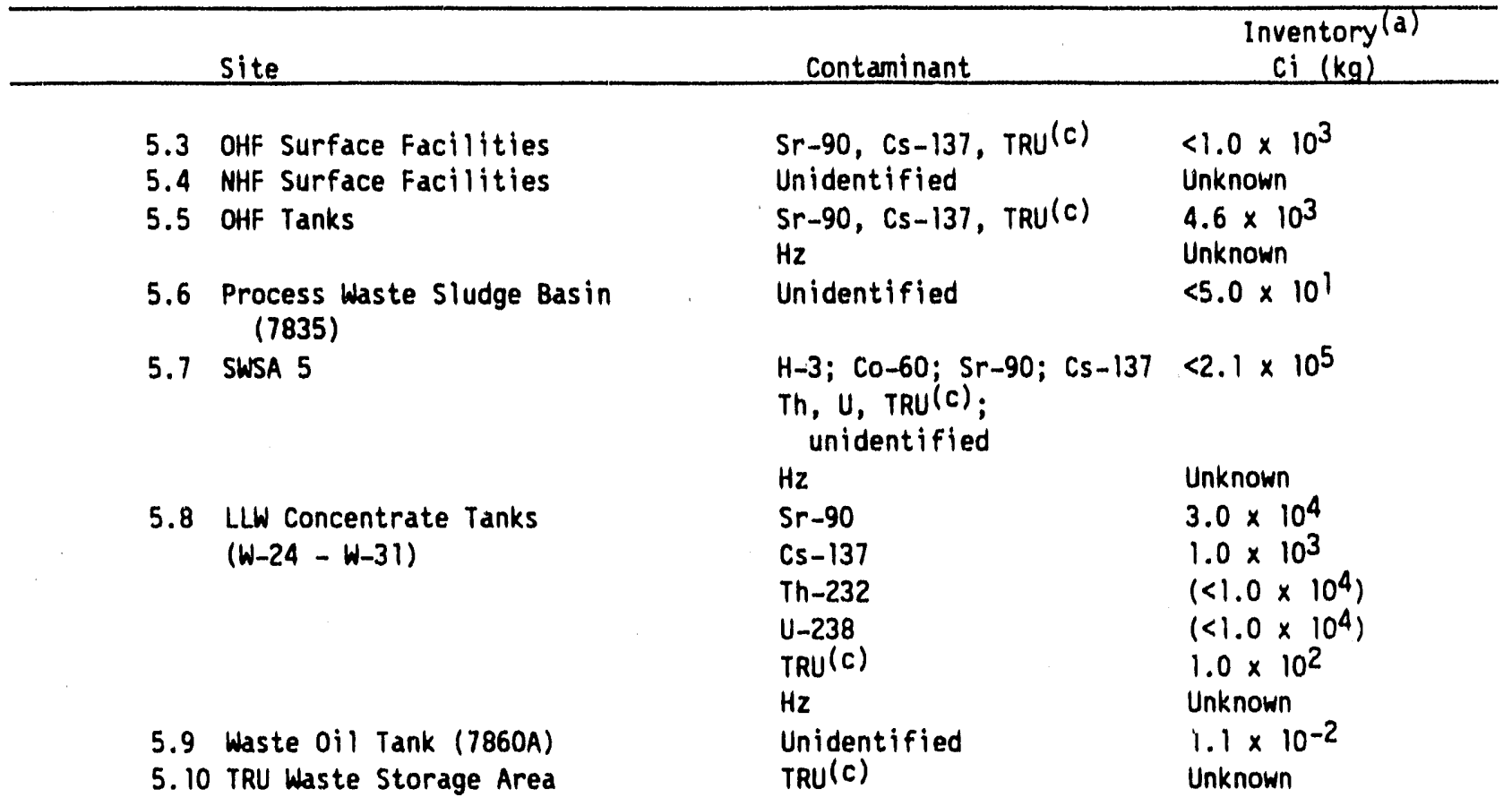

WAG 6: SWSA 6

6.1 SWSA 6 (7822)

$\begin{array}{ll}\text { Unidentified } & <4.8 \times 10^{4} \\ \mathrm{H}-3 & <7.1 \times 10^{3} \\ \mathrm{Co}-60 & <3.2 \times 10^{4} \\ \mathrm{Sr}-90 & <3.0 \times 10^{3} \\ \mathrm{Cs}-137 & <5.1 \times 10^{3} \\ \mathrm{Eu}-152 & <5.1 \times 10^{4} \\ \mathrm{Eu}-154 & <7.3 \times 10^{4} \\ \mathrm{Eu}-155 & <3.1 \times 10^{4} \\ \text { Th-232 } & <2.5 \\ & \left(2.3 \times 10^{4}\right) \\ \text { U-233 } & <2.3 \times 10^{2} \\ \text { U-238 } & <2.1 \times 10^{2} \\ & \left(6.1 \times 10^{5}\right) \\ \text { TRU(c) } & <3.6 \\ \text { Asbestos } & \text { Unknown } \\ \text { Pb } & \left(>6.8 \times 10^{4}\right) \\ \text { Solvents } & \left(>4.3 \times 10^{4}\right) \\ \text { None } & \text { None } \\ \text { None } & \text { None }\end{array}$

6.2 Emergency Waste Bas in (7821)

None

None (7819)

WAG 7: Pits and Trenches

7.1 Decontamination Facility (7819)

7.2 HRE Fuel Wells (7809)

$\begin{array}{ll}\text { Unidentified } & <1.0 \text { est. } \\ \text { Sr-90 } & <2.0 \times 10^{\prime} \\ U-235 & 8.5 \times 10^{-3} \\ & (4.0) \\ U-238 & 2.0 \times 10^{-4} \\ & \left(6.5 \times 10^{-1}\right)\end{array}$


TABLE 5-1 (Continued)

\begin{tabular}{|c|c|c|c|}
\hline & Site & Contaminant & $\begin{array}{l}\text { Invento } \\
\mathrm{Cl}(\mathrm{k} \\
\end{array}$ \\
\hline $\begin{array}{l}7.3 \\
7.4\end{array}$ & $\begin{array}{l}\text { HF So } 1 \text { l contamination } \\
\text { LLW Lines and Leak Sites }\end{array}$ & $\begin{array}{l}\text { Cs-137, Unidentified } \\
\text { Sr-90, Cs-137, TRU(c) } \\
\text { Cm-244 }\end{array}$ & $\begin{array}{l}<1.0 \times 10^{1} \\
<1.0 \times 10^{3}\end{array}$ \\
\hline 7.5 & Pit 1 (7805) & $\begin{array}{l}\text { Cs }-137 \\
\text { Pu-239 }\end{array}$ & $\begin{array}{l}2.3 \times 10^{2} \\
2.1 \times 10^{-2}\end{array}$ \\
\hline 7.6 & Pits 2,3 , and 4 & $\begin{array}{l}\text { Sr }-90 \\
\text { Cs }-137 \\
\text { Pu-239 }\end{array}$ & $\begin{array}{l}4.2 \times 10^{4} \\
1.8 \times 10^{5} \\
2.0 \times 10^{1}\end{array}$ \\
\hline 7.7 & Trench 5 (7809) & $\begin{array}{l}\text { Sr }-90 \\
\text { Cs }-137\end{array}$ & $\begin{array}{l}<9.7 \times 10^{4} \\
2.1 \times 10^{5}\end{array}$ \\
\hline 7.8 & Trench $6(7810)$ & $\begin{array}{l}P u-239 \\
S r-40 \\
C s-137 \\
P u-239\end{array}$ & $\begin{array}{l}1.0 \times 10^{1} \\
1.5 \times 10^{2} \\
6.7 \times 10^{2} \\
1.3 \times 10^{-2}\end{array}$ \\
\hline 7.9 & Trench 7 (7818) & $\begin{array}{l}S r-90 \\
\text { Cs }-137 \\
U-233\end{array}$ & $\begin{array}{l}4.8 \times 10^{4} \\
2.3 \times 10^{5} \\
3.2\end{array}$ \\
\hline & & $U-238$ & $\begin{array}{l}4.0 \times 10^{-2} \\
\left(1.2 \times 10^{2}\right)\end{array}$ \\
\hline & & $\begin{array}{l}\text { PU-239 } \\
\operatorname{TRU}(c)\end{array}$ & $\begin{array}{l}1.2 \times 10^{1} \\
3.9 \times 10^{1}\end{array}$ \\
\hline 7.10 & Shielded Transfer Tanks & Cs-137 & $<2.0 \times 10^{3}$ \\
\hline
\end{tabular}

WAG 8: Melton Valley Area

8.1 HFIR/TRU Ponds

8.2 HF-S2A

8.3 LLW Lines and Leak Sites

8.4 Hazardous Waste Storage Facility (7507)

8.5 Active LLW Tank (WC-20)

8.6 Active LLW Tank (HFIR)

8.7 Active LLW Tanks (T-1, T-2)

8.8 Mixed Waste Storage Pad (7507W)

8.9 Sewage Treatment Plant (7904)

8.10 Silver Recovery Process (7834)
CO-60, Cm-244, TRU (c) Unidentified Cm-244; Unidentified Unidentified

Unidentified Unidentified Unidentified Unidentified Unidentified Unidentified
$<1.0 \times 10^{1}$ $<1.0$ Unknown Unknown

Unknown Unknown Unknown Unknown Unknown Unknown

WAG 9: HRE Area
9.1 HRE Pond
Sr -90
Cs -137
$7.5 \times 10^{1}$
$\operatorname{TRU}(c)$
9.2 LLW Tanks
Sr-90, Cs-137, U
9.3 Septic Tank (7501)
None
$1.6 \times 10^{1}$
$5.0 \times 10^{-4}$ Unknown None

WAG 10: Hydrofracture Wells

10.1 HF Experimental Site 1

10.2 HF Experimental Site 2
$3.5 \times 10^{1}$
$5.0 \times 10^{1}$ 
TABLE 5-1 (continued)

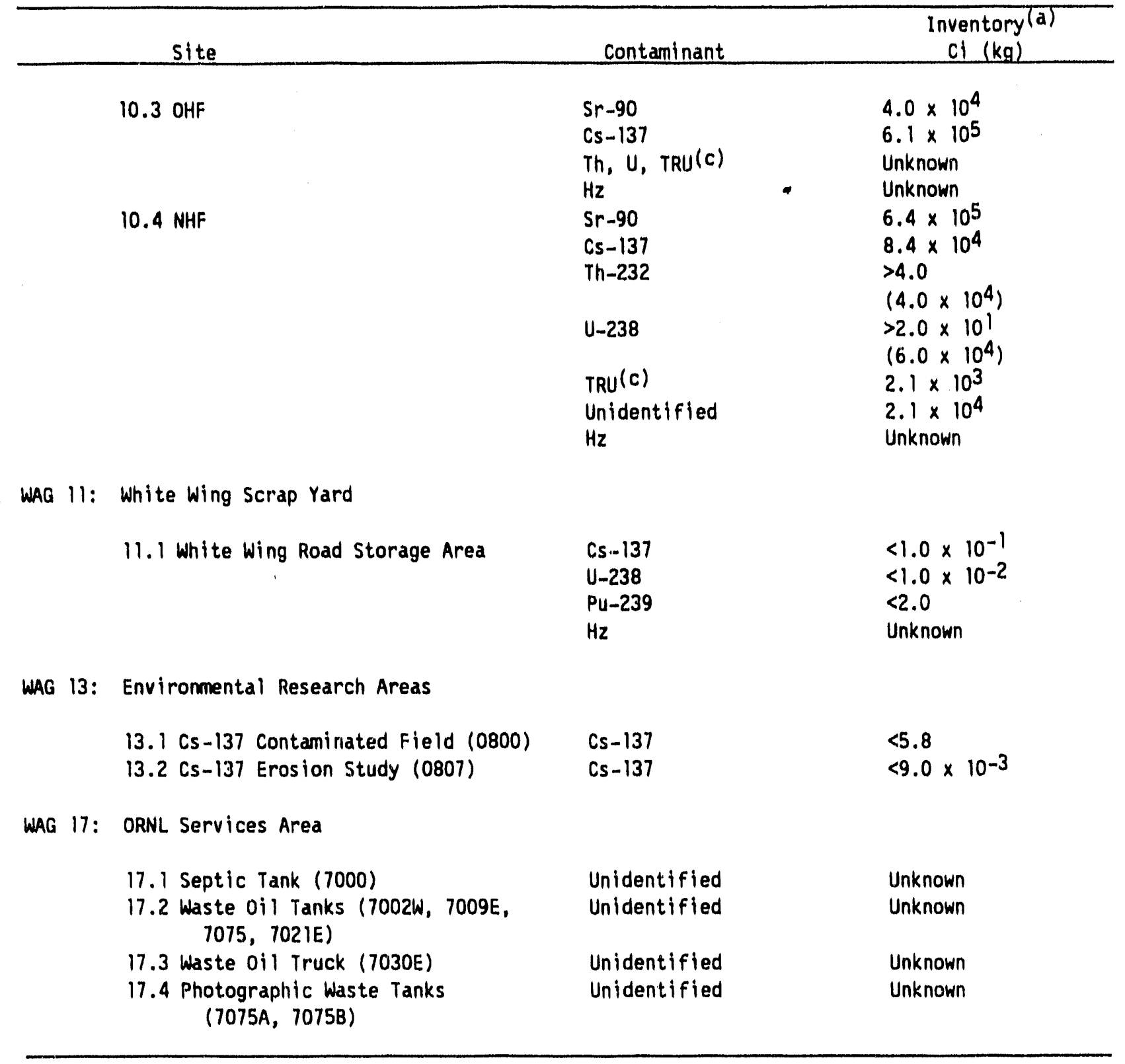

(a) Numbers in parentheses are measured in kilograms.

(b) Inactive refers to tanks no longer in service; active refers to operating tanks.

(c) TRU radionuclides.

Source: RCRA Facilities Assessment (RFA), Oak Ridge National Laboratory, ORNL/RAP-12/VI, March 1987. 
TABLE 5-2

SUMMARY OF KNOWN HAZARDOUS CHFMICALS/COMPOUNDS CURRENTLY USED AND/OR TREATED AT ORNL

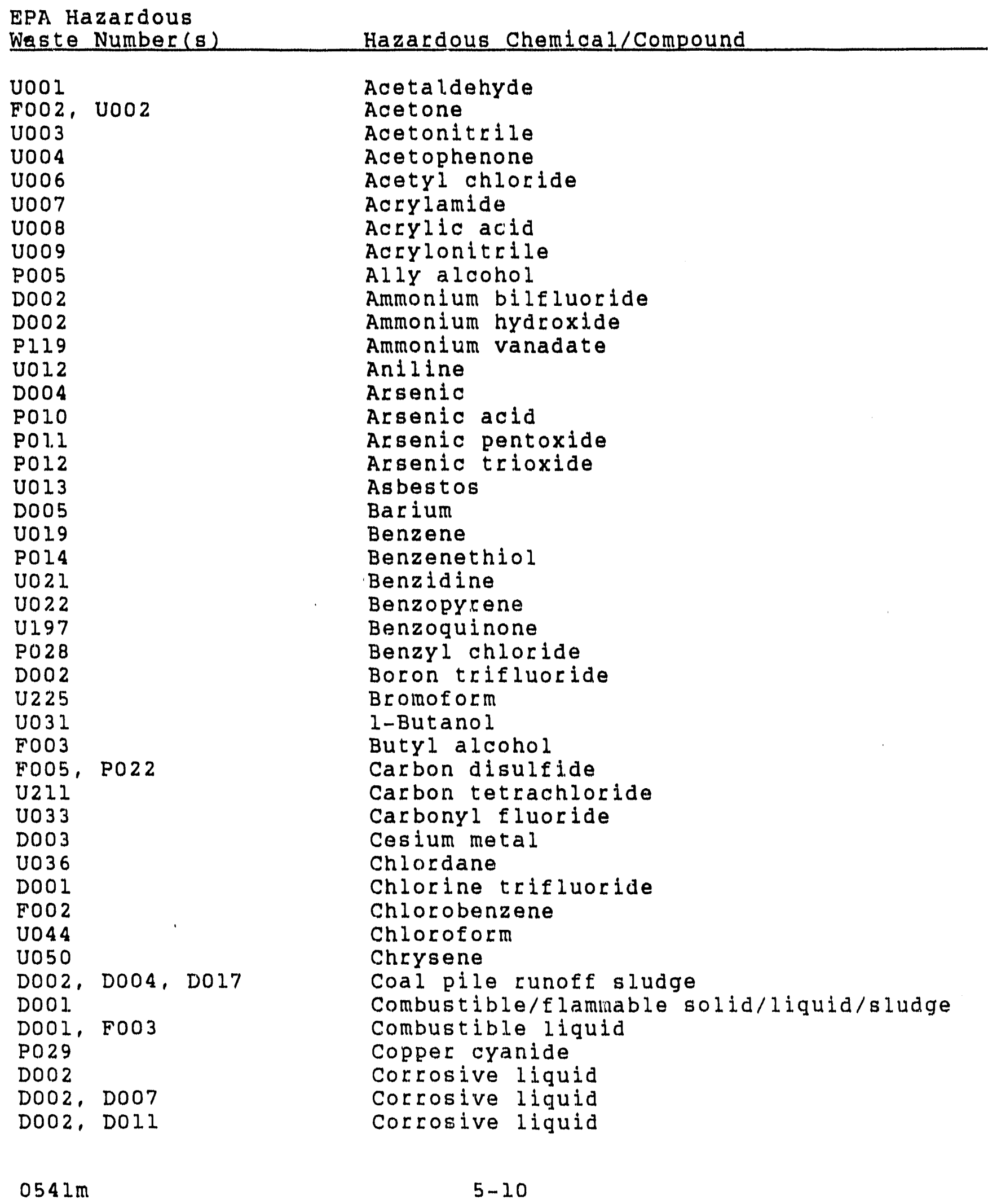


TABLE 5-2 (Continued)

EPA Hazardous

Waste Number (s)

Hazardous Chemioal/Compound

DOO2

D002

$\mathrm{DOO} 2$

D002, D006

FOO4

U052

U053

บ055

P0 30

P031

$\mathrm{PO} 32$

UO56

F003

U061

U069

U070

U071

U072

U075

บ077

บ000

$\mathrm{F} 002$

บ088

U107

U108

UILO

$\mathrm{FOO3}$

U 122

P053

U076

U115

U117

D003

DO04, D017

DOOI

D001

D003

D001, D004, D005, D008

FOOI

FOOL, F0O2

$\mathrm{F} 002$

FOO2, F003

F003, F005

F005

D001

$\mathrm{D} 003$

D001, D009

D004, D017

U122
Corrosive liquid organic acla

Corrosive gas

Corrosive solid

Corrosive solid

Cresol

Cresol

Crotonaldehyde

Cumene

Cyanides

Cyanogen

Cyanogen bromide

Cyclohexane

Cyclohexanone

DDT

Dibutyl phthalate

1,2-Dichlorobenzene

1,3-Dichlorobenzene

1,4-Dichlorobenzene

Dichlorodif luoromethane

1,2-Dichloroethane

Dichloromethane

Dichloromethane

Diethyl phthalate

Di-n-octyl phthalate

1,4-Dioxane

Dipropylamine

Ethyl acetate

Ethyl acetate

Ethylene diamnine

Ethylene dichloride

Ethylene oxide

Ethyl ether

Explosive

Filters (from leachate toxicity testing)

Flammable gas

Flammable liquid

Flammable liquid

Flammable liquid

Flammable liquid

Flammable liquid

Flammable liquid

Elammable liquid

Flamable liquid

Flammable liquid

Flammable solid

Flammable solid

Flammable solid

Flyash

Formaldehyde 
TABLE 5-2 (Continued)

EPA Hazardous

Waste Number (s)

Hazardous Chemioal/Compound

U123

U125

D009

D004, D008

F006

D009

DOO5

D008

DO11

F0O2

DOO4, DOOB

DOOS

D009, DO10

F003, F0O5

DO04, D008

D010, D009

DOO5

DOLI

DOOB

U128

U133

U134

DOO2

D002

F005

DOOI

DOO4-DO17

D008

UI 144

DOO3

F003

DOOI

U 147

U151

U154

FOO3

F001, F003

บOBO

F005

U134

U159

P068

U1 68

DOOI

U165

U167

P073

P075
Formic acid

Furfural

Hazardous substance (Ilquid)

Hazardous substance (Iiquid)

Hazardous substance (solid)

Hazardous substance (solid)

Hazardous substance (solid)

Hazardous substance (solid)

Hazardous substance (solid)

Hazardous substance (solid)

Hazardous waste (liquid)

Hazardous waste (liquid)

Hazardous waste (1iquid)

Hazardous waste (Iiquid)

Hazardous waste (solid)

Hazardous waste (solid)

Hazardous waste (solid)

Hazardous waste (solid)

Hazardous waste (solid)

Hexachlorobutadiene

Hydrazine

Hydrofluoric acid

Hydrogen fluoride

Inorganic acids

Isobutyl alcohol

Isopropyl ether

Laboratory grade chemicals

Leachings from tin/lead plating tank

Lead

Lead acetate

Lithium

Low-level mixed waste water

Magnestum perchlorate

Malelc anhydride

Mercury

Methanol

Methanol

Methanol/trichloroethylene, acetone

Methylene chloride

Methyl ethyl ketone

Hydrofluoric acid

Methyl ethyl ketone

Methyl hydrazine

Methyl isobutyl ketone

Mixed solvents

Napht halene

Naphthylamine

Nickle carbonyl

Nicotine and salts 
TABLE 5-2 (Continued)

EPA Hazardous

Waste Number(s)

Hazardous Chemical/Compound

$\mathrm{D} 002$

$\mathrm{DOO} 2$

FOO4

U169

U170

U178

FO8 7

DOOI

UL82

DOOI

$\mathrm{U} 210$

D003

U188

P095

DOO 2

D011

DO11, D002

DO11

DOII

D002

D002

DOO 3

F009

FOO9

D002, D007

F007

F007

F007

DOO 2

DO04-DOL7

F007

F009

F007

F007

D004

D005

DDO 6

D.-.

$--\cdot-$

D007

D011

D009

D008

$\mathrm{FOO} 2$

F027

D004

D004, D005

D005

D007
Nitric acid solution

Nitric/hydrochloric/hydrofluoric acids

Nitrobenzene

Nitrobenzene

Nitrophenol

n-Nitroso-n-methylurethane

Osmium tetroxide

Oxidizing material (Iiquid/solid)

Paraldehyde

Perchloric acid

Perchloroethylene

Perchloryl fiuoride

Phenol

Phosgene

Phosphorus pentoxide

Photographic waste

Photographic waste

Photographic waste, activator

Photographic waste, activator rinse

Photographic waste, developer

Photographic waste, developer rinse

Picric arid

Plating shop waste (acid dip)

Plating shop waste (cadmium solution)

Plating shop waste (chromic/sulfuric acid)

Plating shop waste (copper/acid)

Plating shop waste (cyanide/carbonate)

Plating shop waste (gold/cyanide)

plating shop waste (hydrochloric acid)

Plating shop waste (lead/tin/acid, solid)

Plating shop waste (nickel)

Plating shop waste (nitric/hydrofluoric acid)

Plating shop waste (preplate silver/cyanide)

Plating shop waste (silver/cyanide)

Poison $B$ liquid

Poison $B$ liquid

Poison B liquid

PNA contaminated waste liquid

PNA contaminated waste solid

Poison B liquid

Poison B liquid

Poison B liquid

Poison B liquid

Poison $B$ liquid

Poison B liquid

Poison B Solid

Poison B Solid

Poison B Solid

Poison B Solid 
TABLE 5-2 (Continued)

EPA Hazardous

Waste Number(s)

Hazardous Chemical/Compound

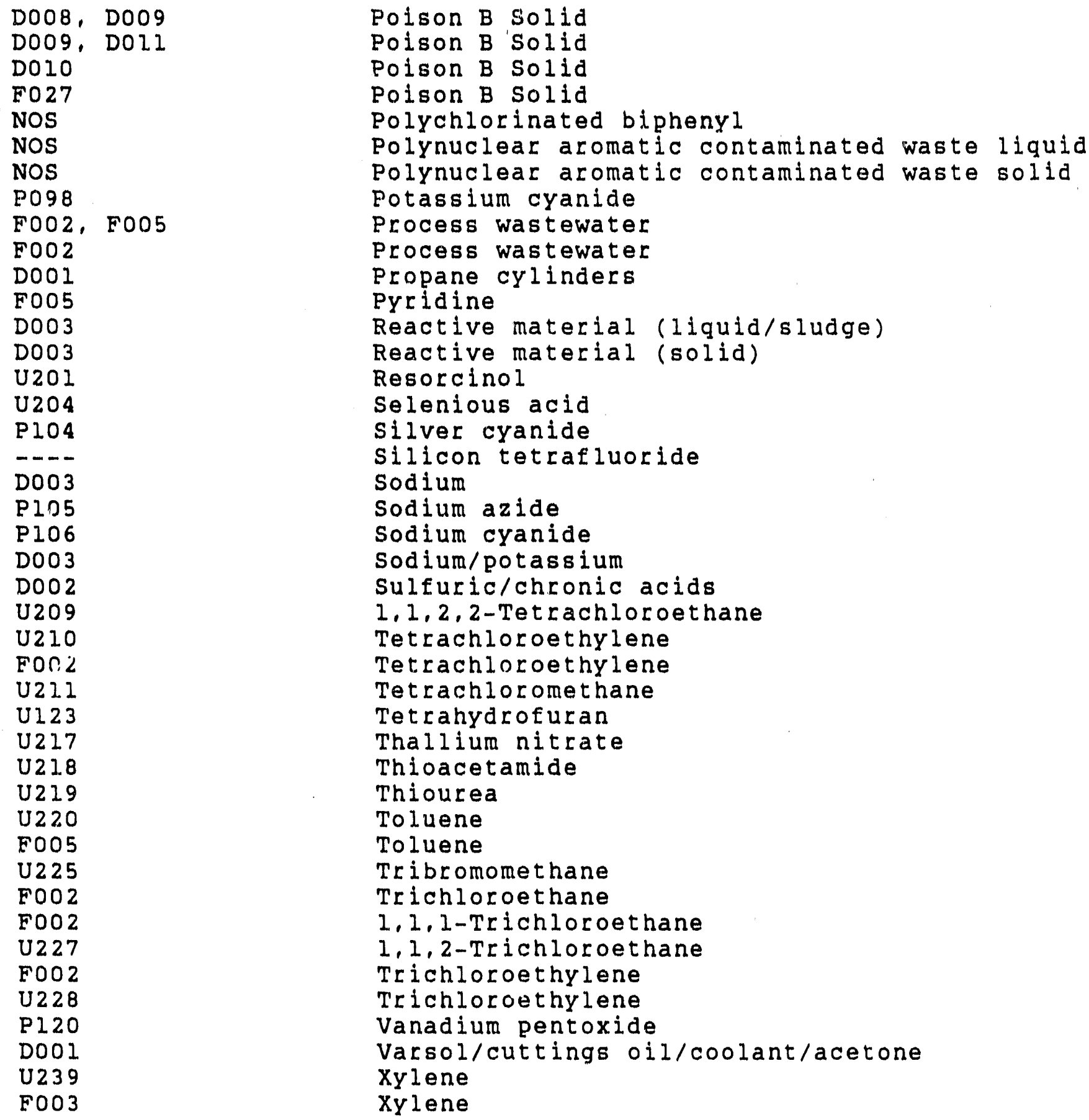

Source: Arınual Hazardous Waste Report, 1986, submitted to the TDHE. 


\subsection{WASTE HANDLING}

Waste handing includes those activities associated with collection, identification, classification, segregation, packaging, certification, and transportation of waste materials. This section provides the definitions and guidance necessary to ensure that RI/FS project waste handing activities are conducted in accordance with Energy systems requirements.

\subsection{SOLID WASTE DEFINITIONS}

Solid waste at the ORNL is divided into three generic categories: radioactive, hazardous/mixed/TSCA, and conventional wastes. Each of these categories is further subdivided; radioactive waste categories are described in subsection 6.1.1 through 6.1.3. Hazardous/Mixed/TSCA wastes are described in subsection 6.1.4. Conventional wastes are discussed in subsection 6.1 .5 .

\section{1 .1 Low-Level Radioactive Waste}

Low-level waste (T.LW) is radioactive waste that cannot be classified, in accordance with DOE Order 5820.2 and 10 CFR 962 definitions, as either high-level waste, TRU waste, spent nuclear fuel, or by-product material. TLW is further defined as those materials containing beta-gamma emitting radionuclides and/or nonfissile alpha-emitting radionuclides. ILW may contain TRU radionuclides if the concentration of those radionuclides is less than $3.7 \times 10^{6} \mathrm{~Bq} / \mathrm{kg}$. LLW may be further categorized as defined in Table 6-1 and as shown in Figure 6-1.

\section{1 .2 LLW Exceptions}

Certain categories of LLW include exceptions not covered in Categories 1 through 4 of $\mathrm{J}$ LW. These exceptions are covered in Categories 5 through 7 , as described in Table 6-1. 
TABLE 6-1

CATEGORIES OF SOLIO WASTE AT

OAK RIOGE NATIONAL LABORATORY

Description

LLW

1. Low-Range Compactible LLW

2. Low-Range Noncompactible LLW

3. High-Range LLH

4. High-Range LLW (Special Case)

\section{LLW EXCEPTIONS}

5. U-235 Waste

6. Suspect LLW
Low-range compactible $L L W$ is defined as those compactible materials (e.g., plastic bags and sheets, paper, cardboard, cloth, rubber gloves and shoe covers, plastic bottles) that exhibit a radiation level at the unshielded package surface of $2 \mathrm{msv} / \mathrm{h}(200 \mathrm{mrem} / \mathrm{h})$ or less.

Low-range noncompactible LLW is defined as those noncompactible materials (e.g., wood, scrap metal, glass bottles, metal tools, equipment) that exhibit a radiation level at the unshielded package surface of $2 \mathrm{mSv} / \mathrm{h}(200 \mathrm{mrem} / \mathrm{h})$ or less.

This category of waste includer all LLW materials that exhibit radiation levels at the unshielded package surface of greater than $2 \mathrm{mSv} / \mathrm{h} \quad(200$ mrem $/ \mathrm{h})$, and less than or equal to $20 \mathrm{mSv} / \mathrm{h}(2$ ren/h).

This category of waste is the same as Category 3 , except that the radiation level at the unshielded package surface is greater than $20 \mathrm{mSv} / \mathrm{h}(2$ rem/h).

This category of waste includes those LLWls which contain one gram of U-235 or more per package. It is anticipated that U-235 wastes will not be encountered, except possibly during WAG 7 investigations in the vicinity of the HRE fuel wells.

Suspect LWW $i$ - defined as those materials with no measurable levels of raotoactivity (by field survey techniques) but judged, because of its history, to be contaminated with radioactive materials in excess of Table 6-3 limits, hence is unsuitable for release from waste management control. 
7. Radioactive Asbestos Waste

9. Remote-Handled TRU

\section{HAZARDOUS/MIXED/TSCA WASTES}

10. Characteristic Hazardous Waste

11. Listed Hazardous Waste

12. Characteristic and Listed Waste

13. LLW Mixed Characteristic Waste
This category of waste includes those LLWS which contain more than one percent friable asbestos, as defined in subpart $M$ of 40 CFR 61 , and Subpart F of 40 CFR 763.
Contact-handled TRU wastes and are those TRU wastes that exhibit radiation levels at the unshielded package surface of $2 \mathrm{msv} / \mathrm{h}$ (200 mrem/h) or less.

Remote-handled TRU wastes are those TRU wastes that exhibit radiation levels at the unshielded package surface of greater than $2 \mathrm{mSv} / \mathrm{h}(200$ mrem/h), but less than $1 \mathrm{~Sv} / \mathrm{h}(100 \mathrm{rem} / \mathrm{h})$.

This category of waste includes those compounds and substances that exhibit one or more of the four characteristics of a hazardous waste as defined in Subpart C of 40 CFR 261. These characteristics (ignitability, corrosivity, reactivity, and EP toxicity) and their regulatory definitions are presented in Attachment $A$.

This category of waste includes those compounds and substances that are listed in Subpart $D$ of 40 CFR 261. These lists include; Hazardous wastes From Non-Specific Sources (40 CFR 261.31), Hazardous Wastes From Specific Sources (40 CFR 261.32), and Discarded Camercial Chemical Products, off-Specification Species, Container Residues and Spill Residues Thereof (40 CFR 261.33); and are shown in Attachment 8 .

This category of waste includes those compounds and substances that are listed wastes, and exhibit one or more of the characteristics of a hazardous waste.

This category of waste includes those compounds and substances that exhibit one or more of the characteristics of a hazardous waste (Attachment A) and are contaminated with LLW materials in excess of Table 6-3 values. This category of waste may be subdivided further as described in Categories $1-4$ above. 
TABLE 6-1 (Continued)

Description

14. LLW Mixed Listed Waste

15. LLW Mixed Characteristic and Listed Waste

16. TRU Mixed Waste

17. LLW Exception Mixed Characteristic Waste

18. LLW Exception Mixed Listed Waste

19. LLW Exception Mixed Characteristic and Listed Waste
This category of waste includes those compounds and substances that are listed in Subpart $D$ of 40 CFR 261 (Attachment B) and are contaminated with $L L W$ materials in excess of Table 6-3 values. This category of waste may be subdivided further as described in Categories $1-4$ above.

This category of waste includes those compounds and substances that are listed in Subpart $D$ of 40 CFR 61 , that also demonstrate one or more characteristics of a hazardous waste, and that are contaminated with LLW materials in excess of Table 6-3 values. This category may be subdivided further as described in Categories $1-4$ above.

This category of waste includes those compounds and substances that are listed in Subpart $D$ of 40 CFR 261, and/or exhibit one or more of the characteristics of a hazardous waste, and/or contain TSCA substances; and that contain concentrations of TRU radionuclides in excess of $3.7 \times 10^{6} \mathrm{~Bq} / \mathrm{kg}(100 \mathrm{nCi} / \mathrm{g})$. This waste category may be subcategorized according to the radiation levels measured at contact with the unshielded surface of the waste package as described in Categories 8 and 9 above.

This category of waste includes those compounds and substances that exhibit one or more of the characteristics of a hazardous waste, and contains Categories 5, 6, or 7, as described above.

This category of waste includes those compounds and substances that are listed in Subpart $D$ of 40 CFR 261 and contains either Category 5, 6, or 7 as described above.

This category of waste includes those compounds and suibstances that exhibit one or more of the characteristics of a hazardous waste, one or more of the compounds that are listed in Subpart $D$ of 40 CFR 261, and that contains either Category 5 , 6 , or 7 as described above. 
20. TSCA Waste

21. Radioactive TSCA Waste
This category of waste includes those compounds and substances contaminated with polychlorinated biphenyls (PCBS), as described in 40 CFR 761. For the purpose of this plan, the phrase PCBs shall include Aroclors 1016, 1221, 1232, 1242, 1248, 1254, and 1260.

This category of waste includes those compounds and substances contaminated with PCBS (as described in (ategory 20 above), and contains radioactive materials in excess of Table 6-3 values. This waste category may be subcategorized according to the radiation levels measured at contact with the unshielded surface of the waste package as described in subsections 6.1 .1 and 6.1.3.

CONVENT IONAL

22. Disposable Waste

23. Scrap Metal Waste

24. Recyclable Waste
This category of waste includes those articles, materials and substances that are no longer of any practical use, and for which it is not economical to recycle or resell (e.g., garbage, refuse, rubbish, glass, wood, concrete, rock, construction debris, etc.).

This category of waste includes scrap metal for which it is economically feasible to segregate from other forms of conventional waste materials for resale purposes.

This category of waste includes those articles and materials for which it is economically feasible to recycle for reuse (e.g., tires, batteries, metal drums, etc.). 


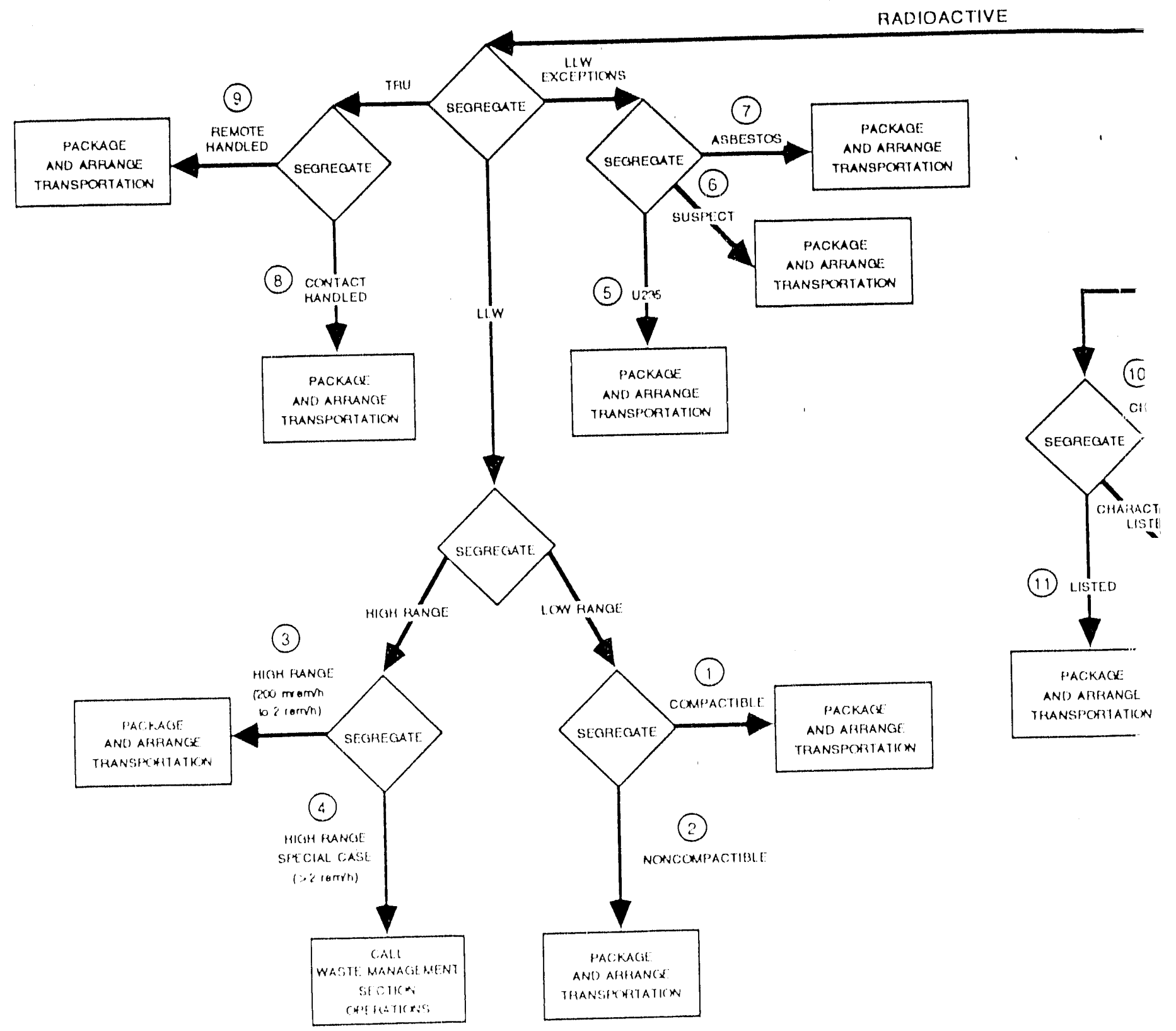




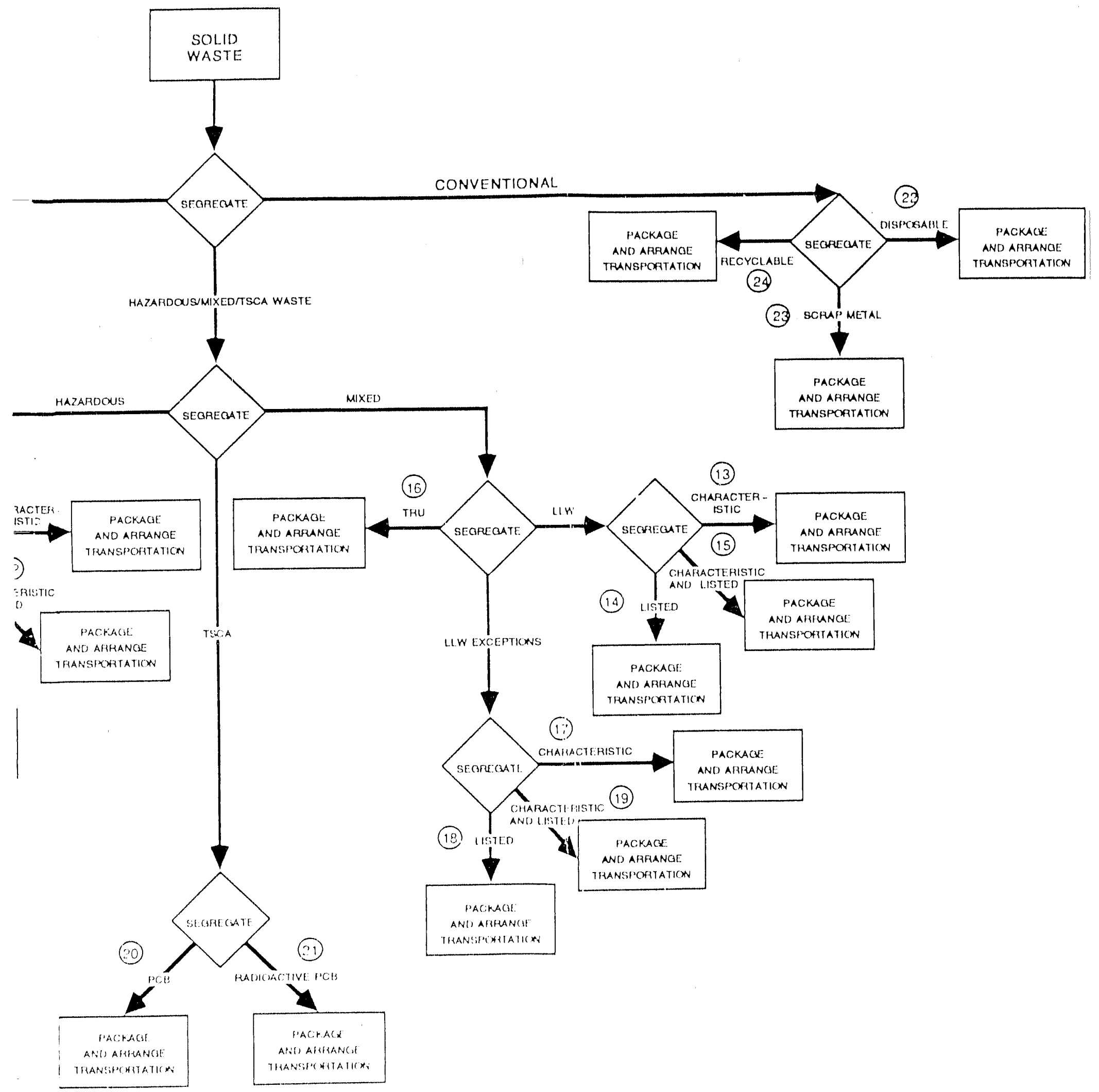

FIGURE $6-1$

SOLID WASTE CATEGORIES SEGREGATION CHART 


\subsubsection{TRU Wastes}

TRU waste is that material that is contaminated to greater than $3.7 \times 10^{6} \mathrm{~Bq} / \mathrm{kg}$ with alpha-emitting radionuclides having atomic numbers greater than 92 and half-lives greater than 20 years. By directive (ORNL Health Physics Procedure 5.1), materials contaminated with radium-226 or uranium-233 to levels greater than $3.7 \times 10^{6} \mathrm{Bg} / \mathrm{kg}$ shall also be treated as TRU waste. TRU wastes are categorized according to radiation levels, as described in Table $6-1$.

\subsubsection{Hazardous/Mixed/TSCA Wastes}

Hazardous chemical wastes at the ORNL are grouped into three generic categories comprised of hazardous, TSCA, and mixed wastes. These generic categories are subdivided as shown in Table 6-1 and in Figure 6-1.

\section{1 .5 Conventional Waste}

This generic category of wastes includes those articles, materials and substances that are no longer of any practical use (e.g.. designated for disposal, recycle, or resale), do not contain significant concentrations of radioactive materials, and do not contain detectable quantities of hazardous chemicals as defined in Table 6-2. This category of waste may be subcategorized as shown in Table 6-1 and in Figure 6-1.

\subsection{LIOUID WASTE DEFINITIONS}

Liquid waste at the ORNL is divided into three generic categories: radioactive, hazardous/mixed/TSCA, and conventional. These generic classifications are further described in the following subsections and in Table 6-3 and Figure 6-2. 
TABLE 6-2

GUIDES FOR UNRESTRICTED RFIJEASE

PARAMETER MEASURED

Nontransferable Gross Alpha Activity

Transferable Gross Alpha Activity

Nontransferable Gross Beta-Gamma Activity

Transferable Beta-Gamma Activity

Volatile organic Conpounds

$\mathrm{pH}$

(water)
ACCFPTABLE VALUE

$<5 \mathrm{~Bq} / 100 \mathrm{~cm}^{2}$

(<300 dpm/100 $\mathrm{cm}^{2}$ )

$<0.33 \mathrm{~Bq} / 100 \mathrm{~cm}^{2}$

(< $\left.20 \mathrm{dpm} / 100 \mathrm{~cm}^{2}\right)$

$<0.2 \mathrm{uGy} / \mathrm{h}$

$(<0.02 \mathrm{mrad} / \mathrm{h})$

$<3.33 \mathrm{~Bq} / 100 \mathrm{~cm}^{2}$

(< $200 \mathrm{dpm} / 100 \mathrm{~cm}^{2}$ )

None Detected(a)

$6 \leq \mathrm{pH}$ Value $\leq 9$

(a) BY EPA accepted portable volatile organics detection techniques and/or head space gas chromatography techniques. 
TABLE 6 6-3

CATEGORIES OF LIQUID WASTE AT

OAK RIDGE NATIONAL LABORATORY

RADIOACTIVE LIQUIO WASTE

1. PWTP Waste

2. Low-Level Liquid Waste

3. TRU Liquid Waste

HAZARDOUS/MIXED/TSCA LIQUID WASTES

4. Characteristic Hazardous Liquid Wastes

5. Listed Hazardous Liquid Waste

6. Characteristic and Listed Hazardous Liquid Waste

7. Mixed PWTP Waste

8. Mixed LLLW
This category of waste includes those liquids containing predominantly strontium-90 and cesium-13\% in concentrations exceeding DOE Order 5480. 1A Concentration Guides (CGs) for water (Chapter XI of 5480.1A, Attachment XI-1, Table II, Column 2), but not exceeding a total beta-gamma activity of $10,000 \mathrm{~Bq} / \mathrm{L}(0.27 \mathrm{uCl} / \mathrm{L})$.

This categary of waste includes those liquids containing concentrations of any radionuclide in excess of the applicable CGs that cannot be classified as either PWTP waste or TRU waste.

This category of waste includes those liquids which contain TRU radionuclides in concentrations exceeding $3.7 \times 10^{6} \mathrm{~Bq} / \mathrm{L}(100 \mathrm{nCi} / \mathrm{mL})$.

This category of waste includes those liquids that exhibit one or more of the four characteristics of a hazardous waste as defined in Subpart C of 40 CFR 261 (see Attachment A).

This category of waste includes those liquids that contain one or more of the contaminants listed in Subpart $D$ of 40 CFR 261 (see Attachment B).

This category of waste includes those liquids that exhibit one or more of the four characteristics of a hazardous waste, and that contain one or more of the contaminants listed in Subpart $D$ of 40 CFR 261.

This category of waste includes those liquids that qualify as PWTP waste, exhibit one or more of the four characteristics of a hazardous waste, and/or contain one or more of the contaminants listed in Subpart $D$ of 40 CFR 261.

This category of waste includes those liquids that qualify as LLLW, exhibit one or more of the four characteristics of a hazardous waste, and/or contain one or more of the contaminants listed in Subpart $D$ of 40 CFR 261.

$$
6-9
$$


9. Mixed TRU Liquid Waste

10. TSCA Liquid Waste

11. Radloactive TSCA Liquid Waste

CONVENTIONAL LIQUID WASTE

12. Uncontaminated Liquid Waste

13. Sanitary Liquid Waste

14. Recyclable 011
This category of waste includes those liquids that quallfy as TRU liquid waste, exhibit one or more of the four characteristics of a hazardous waste, and/or contain one or more of the contaminants Itsted in subpart D of 40 CFR 261.

This category of waste includes those liquids that would otherwise be classifled as uncontaminated liquid waste, but that contain detectable concentrations of polychlorinated biphenyls.

This category of waste includes those liquids that qualify as PCB llquid waste, and that contain concentrations of radioactive material(s) in excess of the applicable CGs.

This category of waste includes liquids that do not exhibit any of the four characteristics of a hazardous waste, do not contain any of the contaminants listed in subpart $D$ of 40 CFR 261, do not contain radionuclides in concentrations exceeding their respective CG values for water, and do not qualify as sanitary liquid waste or recyclable oil.

This category of waste includes those llquids that contain biodegradable materials, do not exhibit any of the four characteristics of a hazardous waste, do not contain any of the contaminants listed in subpart $D$ of $40 \mathrm{CFK} 261$, do not contain any radionuclides in concentrations exceeding their respective CG values for water, and do not qualify as recyclable oil.

This category of waste includes waste olls that do not contain PCBs, do not exhibit any of the four characteristics of a hazardous waste, do not contain contaminants listed in subpart 0 of 40 CFR 261 , and/or do not contain concentrations of radionuclides in excess of their respective CG values. 


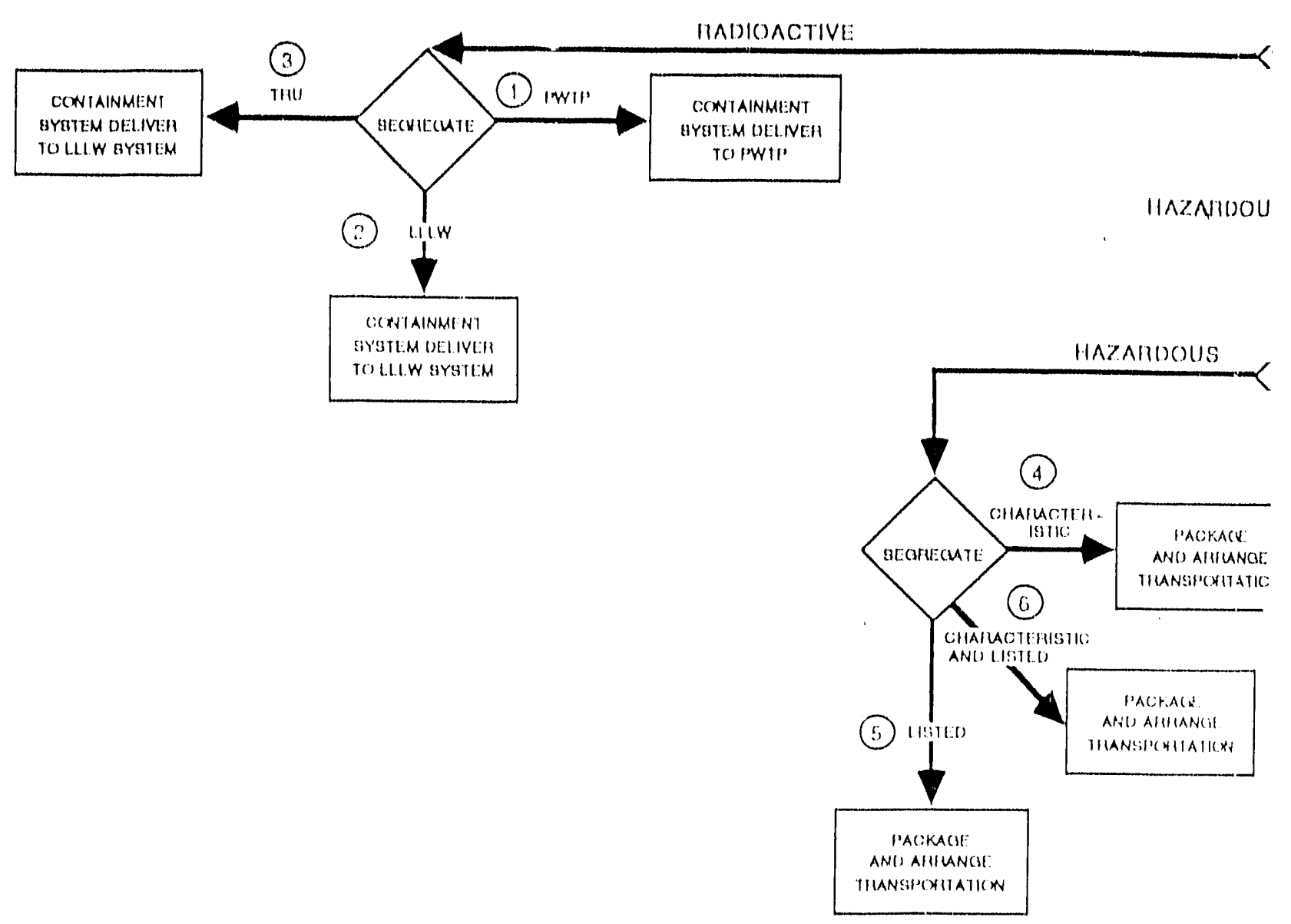

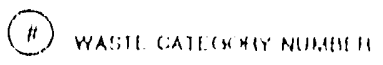

P'AC:KAC. abil ahILAHCH TILANGBDPHIAILA 

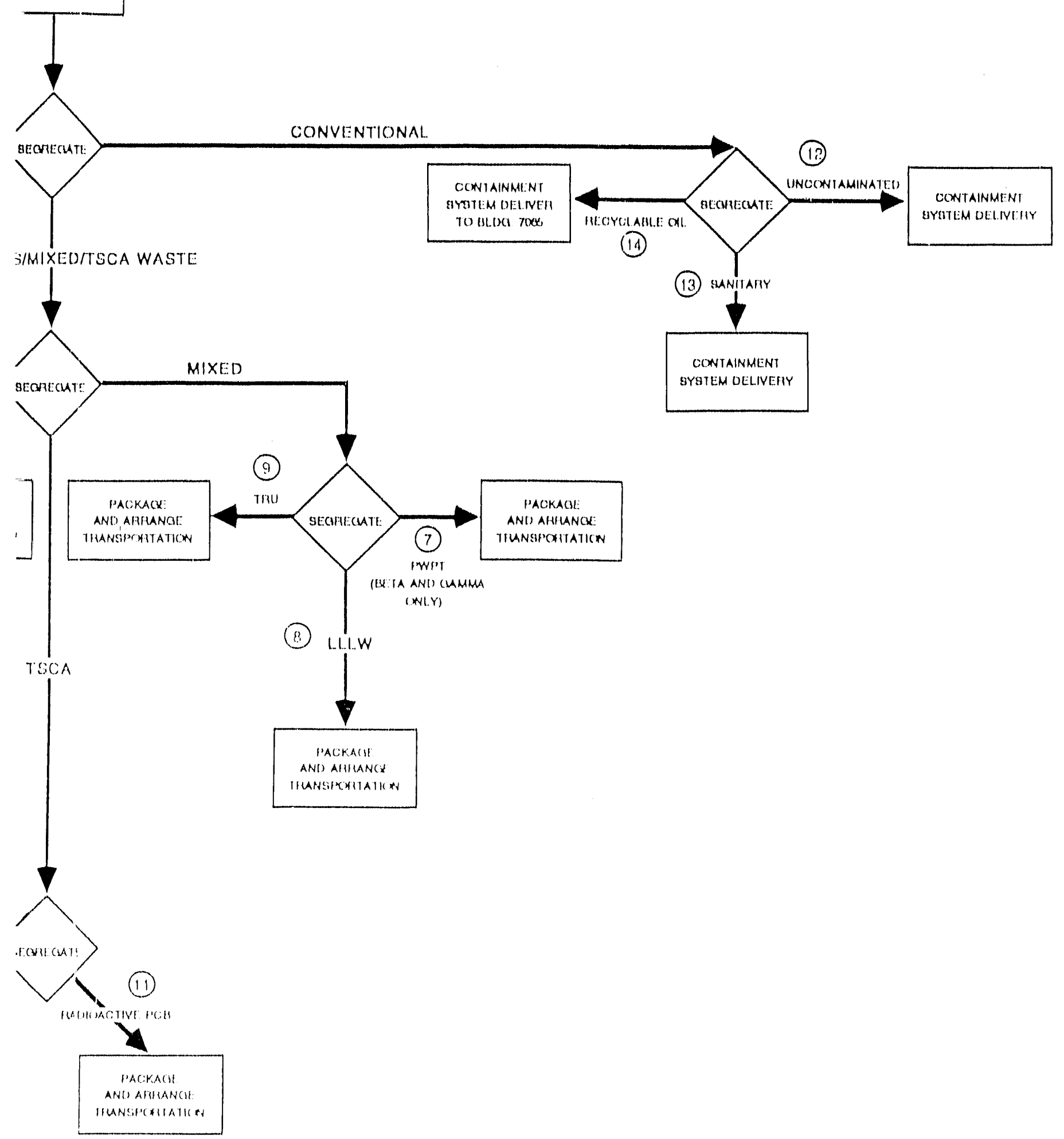

FIGURE 6-2

LIQUID WASTE CATEGORIES SEGREGATION CHART 


\subsubsection{Radioactive Liquid Waste}

Radioactive liquid waste may be subcategorized according to radionuclide content and concentration. Categories are described in Table 6-3.

\subsubsection{Hazardous/Mixed/TSCA Liquid Waste}

Hazardous/mixed/TSCA liquid waste may be subcategorized according to contaminant content and concentration, as described in Table 6-3.

\subsubsection{Conventional Liquid Waste}

Conventional liquid wastes are subcategorized according to the waste's constituents, as described in Table 6-3.

\subsection{COLLECTION OF WASTE MATERIALS}

All materials used or generated by ORNL RI/FS project field activities that are no longer of use and are intended for recycle or disposal will be classified as solid waste, in accordance with the definition given in 40 CFR 261.2 , "Definition of solid Waste." Accordingly, all such waste material will be collected in appropriate containers, containment devices, or areas until they can be properly characterized, segregated, and packaged for recycle, treatment, storage, or disposal.

These waste collection activities will be conducted to ensure the following:

- Minimize waste volumes

- Protect the public health and welfare and prevent contamination of the environment

- Maintain personnel exposures to hazardous contaminants and radiation as low as reasonably achievable (ALARA) 
- Comply with the waste management requirements of federal and state regulations, DOE orders, and ORNL procedures

These goals will be achieved through execution of an integrated system of ORNL RI/FS project procedures, as described in the following subsections.

\section{3 .1 Training}

All individuals involved with waste handling (e.g., collection, identification, segregation, classification, certification, and packaging) will be trained in accordance with the requirements described in section 3.0. This training stresses the importance of, and mandates adherence to, this plan and its related project procedures and proviles guidance for practical application of ALARA and waste minimization techniques.

\subsubsection{Minimization}

All reasonable efforts will be made to minimize the quantity of waste materials generated during ORNL RI/ES project field activities. These efforts will include but are not limited to the following:

- Review of all planned activities or operations to ensure that potential waste-producing activities are necessary and that they are designed to ensure waste minimization

- Routine audits by cognizant ES\&H staff members to ensure compliance with applicable project procedures

- Segregation, in accordance with this plan and project Procedure 1401, to ensure that uncontaminated materials are not mixed with contaminated materials or that different categories of waste are not mixed

- Decontamination to reduce volume and/or to meet orNL waste acceptance criteria

The following paragraphs describe decontamination methods that may be used during ORNL RI/FS project field activities. 
6.3.2.1 Equipment Decontamination. If necessary, decontamination of equipment for unrestricted use (e.g.. split-spoon samplers, auger stems and flights) will be performed at the field location in accordance with RI/FS Project Procedure 1250, "Equipment Decontamination and Release for Unrestricted Use." Field decontamination efforts will be conducted so as to prevent the spread of contamination and minimize waste generated during the process. Typical precautions will include the use of buckets, ground covers, and waste receptacles to ensure containment.

In accordance" with the ORNL "Health, Safety, and Environmental Protection Procedures for Excavating operations" (Attachment $C$ ), removable contamination will be reduced to less than 0.33 alpha $\mathrm{Bq} / 100 \mathrm{~cm}^{2}$ and/or to less than 3.3 beta-gamma $\mathrm{Bq} / 100 \mathrm{~cm}^{2}$. Fixed contamination will be reduced to less than 5.0 alpha $B q / 100 \mathrm{~cm}^{2}$ and/ur to less than $0.5 \mathrm{ugy} / \mathrm{h}$ of beta-gamma activity.

Equipment which cannot be field decontaminated to meet the fixed contamination 1 imits and exhibits beta-gamma contamination (as measured at one centimeter by an end-window GM survey meter) of 30,000 counts per minute or less (hot spots of 150,000 counts per mincte or less are permitted, if the hot spot is limited to 100 $\mathrm{cm}^{2}$ or less) and alpha contamination of $83.3 \mathrm{~Bq} / 100 \mathrm{~cm}^{2}$ or less (ORNL, 1986) will be taken to the ORNL Equipment cleaning Facility (Building 7935) for final decontamination.

Equipment contaminated in excess of the acceptance criteria for, or that cannot be decontaminated to meet the fixed contamination limits by, the ORNL Equipment cleaning Facility, will be taken to the on-site BNI decontamination trailer for final decontamination. The BNI decontamination trailer is designed to be the functional equivalent of a DOT specification $7 \mathrm{~A}$ container, in accordance with the specifications of 49 CFR 173.425 (b) and 49 CFR 178.350, and to meet plant technical specifications for NRC licensed commercial nuclear power plants. Contaminated item acceptance criteria for the BNI decontamination trailer is normally established on a

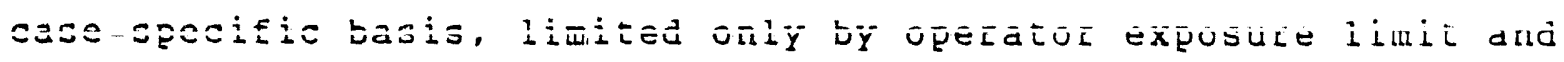


ALARA considerations. For the purposes of this plan, however, the ORNL contact-handled limit of $2 \mathrm{mSv} / \mathrm{h}$ at the item surface will be used as acceptance criteria for fixed contamination. Liquids and solids used in the BNI decontamination trailer will be recycled to the extent practical to limit the volume of wastes generated during the process. Airborne contamination is processed through demisters and HEPA filters prior to discharge. Waste materials generated by the BNI decontamination trailer. will be handled in accordance with this plan. Solid and liquid waste will be separated such that both waste forms meet ORNL waste acceptance criteria. Equipment that cannot be decontaminated to meet the fixed contamination limits, or are in excess of the established acceptance criteria, will be disposed as solid wastes, in accordance with the provisions of this plan.

6.3.2.2 RCRA Cleaning. After radiological decontamination (if any) and release for unrestricted use, equipment to be reused for sampling purposes (e.g.. sampling tools, drill flights, augers, drill stems) will be cleaned of any potentially remaining chemical contaminants. This RCRA cleaning will be accomplished at the ORNL RCRA Cleaning Area. Waste liquids generated by the cleaning process will be discharged through the facility's silt fence. Solid waste generated by the cleaning process will be handled as conventional waste, in accordance with the provisions of Paragraph 6.5.22.

6.3.2.3 Solid Wastes. When practical or economical to do so, solid wastes will be decontaminated. Reusable items such as personal protective equipment (PPE) will be laundered and/or cleaned using on-site BNI or ORNL laundry and cleaning facilities. BNI facilities will utilize processes to minimize waste generation (e.g., dry sleaning). Also, to minimize the volume of waste, cleaning agents will be recycled and decontaminated to the maximum extent practical. Waste materials generated by BNI facilities will be handled in accordance with the provisions of this plan. 
Solid wastes for which decontamination is either impractical or uneconomical will be decontaminated to remove free standing or excessive absorbed liquids. Prior to packaging, bottles will be well-drained; absorbents (e.g., paper, cloth) will be squeezed dry; and if practical. liquids on or in porous materials (e.g.. mops, wood) will be allowed to air dry. Slurries, sludges, and/or very wet drilling spoils will be processed through filter presses andor mixed with ORNL-approved solidifying agents to absorb and fix the moisture.

6.3.2.4 Liquid Wastes. Liquid wastes generated by ORNL RI/FS project field activities (e.g.. drilling muds, well development liquids, decontamination fluids) may be decontaminated to meet ORNL waste acceptance criteria. Decontamination may include such measures as pH adjustment, filtering, gravity settling, and ion exchange. Liquid wastes will not be decontaminated without specific direction from the Energy Systems Field Coordinator.

\subsubsection{Containment}

Waste materials generated by ORNL RI/FS project field activities will be collected or contained until they can be characterized and segregated in accordance with the provisions of this plan. To the extent practical, these practices will include appropriate segregation concurcent with collection and containment. For example, separate containers would be provided for disposable protective clothing and reusable protective clothing; compactible and noncompactible materials; reusable or recyclable materials; and materials of no further use.

Collecticn and containment practices will be planned and designed to preclude contamination of the surrounding work area and the environment. These practices will include, but not be limited to, such precautions such as: 
- Positive containment (e.g., tanks, drums) of liquid wastes

- The use of ground covers, drill pans, metal drums, or lugger boxes for confinement of drill spills

- Keeping dry and dusty drill spoils moistened as they are generated

- Work area perimeter monitoring to document the effectiveness of containment practices

\subsubsection{Health and Safety Monitoring}

Activities generating waste known or suspected to be contaminated with radioactive or chemically hazardous materials will be monitored continuously by H\&S personnel. If conditions other than those permitted by the Hazardous Work Permit (HWP) are encountered, operations shall be halted until such time that provisions are made to allow work to proceed in an ALARA fashion. Such provisions may include increasing PPE requirements or using remote handing equipment and/or shielding. In accordance with the requirements of the ORNL RI/FS ES\&H PIan (BNI, 1987b), ALARA reviews of similar operations (e.g., shallow subsurface soil sampling) will be conducted to identify sources of unnecessary personnel exposure and to ascertain whether additional administrative or engineered controls would reasonably reduce exposures.

\subsection{CHARACTERIZATION AND SEGREGATION}

Waste materials generated ty RI/FS project field investigations (e.g., drilling spoils and muds, well development liquids, used protective :lothing, decontamination residues) will be monitored for radioactive and chemicaliy hazardous contaminants. To the extent practical, monitoring (with portable survey equipment of sufficient sensitivity and range to obtain readings that can confidently be

- compared to the limits given in Table 6-2) and segregation will be accomplished concurrent with waste generation. Typical portable instrumentation will at a minimum include shielded thin-window GM, alpha scintillation, volatile organics, and $\mathrm{pH}$ detection equipment. 
To the extent practical, solid wastes will be physically segregated as they are generated. Segregation will include, but will not be limited to, individual containers, containment devices, or areas for the following:
- Reusable protective clothing
- Compactible waste
- Noncompactible waste
- Glassware
- Items that can be decontaminated
- Soils or soil-like materials

Additional segregation in accordance with section 6.1 requirements may be required, depending on contaminant content or radiation levels at the exterior of the waste package.

\subsubsection{Characterization and Segregation of Soils}

Soil or soil-like materials constitute a special waste category that will be segregated in accordance with the ORNL "Health, safety, and Environmental Protection Procedures for Excavating operations" (Attachment $C$ ). These categories and segregation requirements are summarized in the following paragraphs.

Category I. Category I soils are those that, by direct field screening measurements, exhibit less than 5.0 alpha Bq/100 $\mathrm{cm}^{2}$; less than 0.2 uGy/h of beta-gamma activity; and no detectable volatile organics during the drilling/excavating process. In addition, equipment producing Category I soils must exhibit less than 0.33 alpha $\mathrm{Bq} / 100 \mathrm{~cm}^{2}$ and less than 3.3 beta-gamma Bq/100 $\mathrm{cm}^{2}$ transferable contamination. If there is historical evidence of alpha or low-level beta-gamma contamination, or if field screening measurements exceed any of the foregoing limits, a representative sample will be analyzed for radioactive or chemically hazardous contaminants, as appropriate. 
By laboratory analysis, Category I soils are those soils that exhibit contamination less than or equal to 0.33 alpha $\mathrm{Bq} / \mathrm{g}$ and less than or equal to 1.8 beta-gamma $\mathrm{Bq} / \mathrm{g}$, and show concentrations of hazardous chemical substances less than the values listed in Table 6-4. Category I soils will be segregated from all other categories of soil.

Category II. Category II soils are those that, by direct field screening measurements, exhibit equal to or greater than 5.0 alpha $\mathrm{Bq} / 100 \mathrm{~cm}^{2}$ and less than 100 alpha Bq/100 $\mathrm{cm}^{2}$; beta-gamma activity equal to or greater than $0.2 \mathrm{ugy} / \mathrm{h}$ and less than $50 \mathrm{ugy} / \mathrm{h}$; and no detectable volatile organics during the drilling/excavating process.

By laboratory analysis, Category II soils are those soils that exhiblt greater than 0.33 alpha $\mathrm{Bq} / \mathrm{g}$ and less than 0.75 alpha $\mathrm{Bq} / \mathrm{g}$; greater than 1.8 beta-gamm $\mathrm{Bq} / \mathrm{g}$ and less than 450 beta-gamma Bq/g; and concentrations of hazardous chemical substances less than the values in Table 6-4. Category II soils will be segregated from all other categories of soil.

Category III. Category III soils are those that, by direct field screening measurements, exhibit equal to or greater than 100 alpha $\mathrm{Bq} / 100 \mathrm{~cm}^{2}$; equal to or greater than $50 \mathrm{uGy} / \mathrm{h}$ of beta-gamma activity; and no detectable volatile organics during the drilling/excavating process.

Category II soils are those soils that, by laboratory analysis, exhibit equal to or greater than 0.75 alpha $\mathrm{Bq} / \mathrm{g}$; equal to or greater than 450 beta-gamma Bq/g; and concentrations of hazardous chemical substances less than those values shown in Table 6-4. Category II soils will be segregated from all other categories of soil and will be subject to further categorization in accordance with the provisions of subsection 6.1 . 
Chemical

Acrylamide

Acrylonitrile

Aldrin

Allyl alcohol

Aluminum phosphide

Aniline

Antimony

Arsenic

Barium cyanide

Benz (a)anthracene

Benzene

Benzo(a)pyrene

Beryllium

Bis (2-chloroethyl)ether

Bis (chloromethyl)ether (BCME)

P, is (2-ethyl hexyl) phtha late

Bromoethane

Cacodylic Acid (Hydroxydimethylarsine oxide)

Cadmium

Calcium cyanide

Carbon disulfide

Carbon tetrachloride

Chlordane

Chlorine cyanide

1-Chloro-2,3 efoxypropane (Epichlorohydrin)

Chloroform

Chloromethyl Methyl Ether (CMME)

Chromium (III)

Chromium (VI)

Copper cyanide

Cresols

Cyanide

Cyanogen

2, 4-D

DDT

Dibenz $(a, h)$ anthracene

l.,2-Di.bromo-3-chloropropane (DBCP)

1,2-Dibromoethane

Di-n-Butyl phthalate

Dichlorodifluoromethane

1,2-Dichloroethane

I. I Dichloroethylene

Dichloromethane (Methylene chloride)

2,4-Dichlorophenol

Dieldrin

Diethyl phthalate
Concentration(a)

$(\mathrm{mg} / \mathrm{kg})$

$2 \mathrm{E}-01$

$1 \mathrm{E}+00$

$4 \mathrm{E}-02$

$4 \mathrm{E}+03$

$3 \mathrm{E}+02$

$3 E+02$

$3 E+02$

$4 \mathrm{E}-02$

$5 E+04$

2E-0I

$2 \mathrm{E}+01$

$6 \mathrm{E}-02$

$4 E+03$

$6 \mathrm{E}-01$

$7 E-02$

$1 E+04$

$3 E+02$

$7 \mathrm{E}+03$

$-\cdots--$

$3 E+04$

$7 \mathrm{E}+04$

$5 E+00$

$4 \mathrm{E}+01$

$4 E+04$

$7 E+01$

$9 \mathrm{E}+00$

$7 \mathrm{E}-02$

$7 \mathrm{E}+05$

$-\cdots-$.

$5 E+04$

$4 E+04$

$1 E+04$

$3 E+04$

$6 E+03$

$7 E-01$

1E-02

$3 \mathrm{E}-02$

$2 \mathrm{E}-02$

$7 E+04$

$1 \mathrm{E}+05$

$8 \mathrm{E}+00$

$1 \mathrm{E}+01$

$6 \mathrm{E}+01$

$2 \mathrm{E}+03$

$4 \mathrm{E}-02$

$9 E+06$ 
Chemical

Diethylstilbestrol (DES)

Dimethoate

2,4-Dinitrophenol

2,4-Dinitrotoluene

1,4-Dioxane

Diphenylamine

Disulfoton

Endosulfan

Ethylene oxide

Fluorine

Formic Acid

Heptachlor Epoxide

Hexachlorobenzene

Hexachlorobutadiene

Hexachlorocyclopentadiene

Hydrogen cyanide

Hydrogen sulfide

Hydrazine, Hydrazine sulfate

Lindane (Hexachlorocyclohexane)

Maleic hydrazide

Mercury

Mercury fulminate

Methomy 1

3-Methyl-cholanthrene

4, 4-methlene-bis-2-chloroaniline

Methyl ethyl ketone (MEK)

Methyl ethyl ketone Peroxide (2-Butanone peroxide)

Methyl mercury

Nickel

Nickel cyanide

Nitric oxide

Nitrobenzene

Nitrogen dioxide

2-Nitropropane

N-Nitrosodimethylamine (Dimethylnitrosamine)

$\mathrm{N}-\mathrm{Nitroso-N-methyl} \mathrm{urea}$

$\mathrm{N}-\mathrm{Nit}$ roso-pyrollidine

Pentachlorobenzene

Pentachloronitrobenzene

Pentachlorophenol

Perchloroethylene (Tetrachloroethylene)

Phenol

m-Phenylenediamine

Phenyl mercuric acetate

Potassium cyanide

Potassium silver cyanide

Pronamide (Kerb)

Pyridine
Concentration(a) $(\mathrm{mg} / \mathrm{kg})$

$1.8-03$

$1 E+04$

$2 \mathrm{E}+03$

$2 \mathrm{E}+00$

$1 \mathrm{E}+02$

$2 \mathrm{E}+04$

$3 E+01$

$1 \mathrm{E}+01$

$2 \mathrm{E}+00$

$4 \mathrm{E}+04$

$1 \mathrm{E}+06$

$2 \mathrm{E}+01$

4E-0I

$9 E+01$

$5 E+03$

$1 \mathrm{E}+04$

$2 \mathrm{E}+03$

$7 \mathrm{E}-02$

$2 E+02$

$4 \mathrm{E}+05$

$1 \mathrm{E}+03$

$2 \mathrm{E}+03$

$2 \mathrm{E}+04$

$7 \mathrm{E}-02$

$4 \mathrm{E}+00$

$4 \mathrm{E}+04$

$6 \mathrm{E}+03$

$2 \mathrm{E}+02$

-...

$1 E+04$

$7 \mathrm{E}+04$

$4 \mathrm{E}+02$

$7 \mathrm{E}+05$

$7 \mathrm{E}-02$

$3 E-02$

$2 \mathrm{E}-03$

$3 \mathrm{E}-01$

$6 \mathrm{E}+02$

$3 \mathrm{E}+01$

$2 \mathrm{E}+04$

$1 E+02$

$7 E+04$

$4 \mathrm{E}+03$

$6 \mathrm{E}+04$

$2 \mathrm{E}+02$

$4 \mathrm{E}+04$

$1 E+05$

$5 \mathrm{E}+04$

$1 E+03$ 
TABLE 6-4 (Continued)

\begin{tabular}{|c|c|}
\hline Chemical & $\begin{array}{c}\text { Concentration(a) } \\
(\mathrm{mg} / \mathrm{kg})\end{array}$ \\
\hline 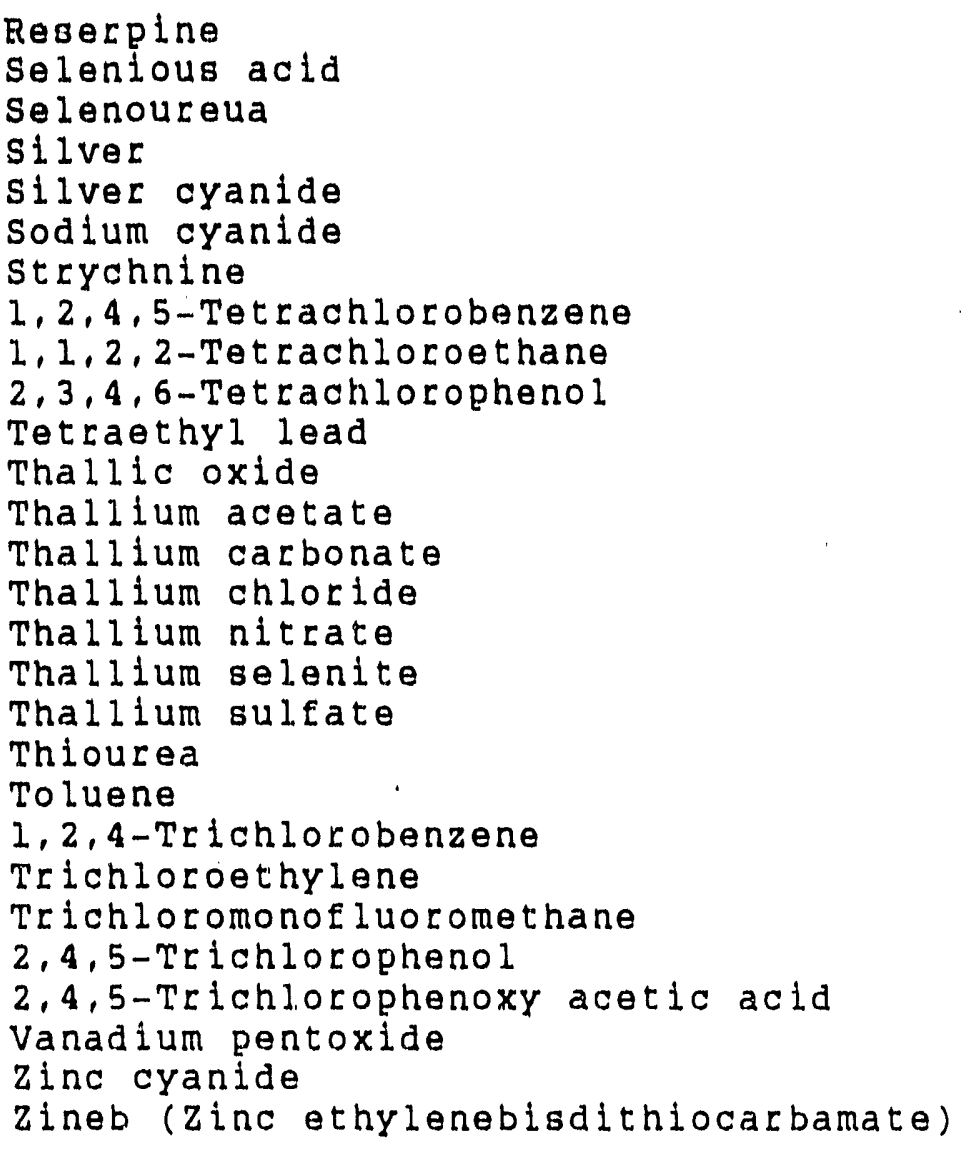 & $\begin{array}{l}7 E-02 \\
2 E+03 \\
4 E+03 \\
2 E+03 \\
7 E+04 \\
3 E+04 \\
2 E+02 \\
2 E+02 \\
4 E+01 \\
7 E+03 \\
7 E+01 \\
3 E+02 \\
4 E+02 \\
3 E+02 \\
4 E+02 \\
4 E+02 \\
4 E+02 \\
4 E+02 \\
4 E-01 \\
2 E+05 \\
1 E+04 \\
6 E+01 \\
2 E+05 \\
7 E+04 \\
2 E+04 \\
1 E+04 \\
4 E+04 \\
4 E+04\end{array}$ \\
\hline
\end{tabular}

(a) These criteria are based on federal guidance; U.S. EPA, Waste Management Division, Office of Solid Waste, Draft RCRA Facility Investigation (RFI) Guidance, EPA 530/SW-87-001, 4/87; and are subject to change. Errata to this plan will be issued as changes are published.

In those cases where the criterion is less than the limit of detection (e.g., DES, N-Nitroso-N-,ethyl urea, etc.), the detection limit shall be used as a default value.

The "UNITY RULE" shall be applied where two or more chemicals are detected, as shown in Equation 6-1.

$$
H I=n \quad \text { (Equation } 6-1 \text { ) }
$$


where; HI = the hazard index, which must be equal to or less than "Unity" ( 1.0$)$, or else the criterion for the chemical mixture has been exoeeded.

$c_{1}$ a concentration of the ith toxicant and/or oarcinogen

$A L_{1}$ a maximum acceptable level of the ith toxicant and/or carcinogen

$\mathrm{n}=$ total number of toxicants or darcinogens 
Solis exhiblting conoentratious of hazardous substances in excess of the limits expressed in Table 6-4 will be categorized as Hazardous/Mixed/TSCA wastes in adoordance with the provisions of Subsection 6.1.4.

\subsubsection{Characterization and Segregation of Liquid wastes}

As they are generated, liquid wastes will be containerized in mud tanks, bladder tanks, steel drums, tank trucks, or other such containers as appropriate. Jiquid wastes will be fleld screened using portable beta-gamma, volatile organics, and pH detection equipment. Positive fleld measurements significantiy in excess of the instruments' background, and/or with pH values less than 6 or greater than 9, will require analytical assessment of contaminant concentrations.

Liquid wastes that are suspected of being contaminated with radioactive and/or hazardous chemical materials but which pass field screening assessments will be analytically screened in the on-site close support laboratory (CSL). Analytical screening will include gross alpha, gross beta, and gas chromatography (GC) measurements. Liquid wastes that exhibit a total radioactivity content of less than $9.0 \mathrm{Bg} / \mathrm{L}$ and less than or equal to the method detection limit for GC analysis will be considered uncontaminated and will be treated as a conventional liquid waste (see subsection 6.2). CSL analytical screening results in excess of these levels will require analytical assessment of contaminant concentrations. This characterization rationale will be used to classify liquid wastes in accordance with subsection 6.2 categories. Liquid wastes exhibiting similar contaminant profiles may be composited into larger and more environmentally stable containers (e.g., CSL liquid wastes into holding tanks) to provide more efficient scheduling of treatment and disposal and to minimize transportation hazards. 


\subsubsection{Characterization and Segregation of Laboratory Wastes.}

Solid and liquid wastes generated by the CSL will be collected, segregated, classified, packaged, certifled, and transported in accordance with the provisions of this plan and its implementing procedures.

Off-site laboratories will, upon completion of analysis, archive all sample extracts, fractions, and remainders for periods of up to 6 months. At the end of the archival period, or at BNI's direction, sample extracts, fractions, and remainders will either be routed to the RI/FS project archive at the DOE's K-25 facility or returned to the ORNL for handing in accordance with this plan and its implementing procedures. Other solid and liquid wastes generated by off-site laboratories that are uniquely identifiable with RI/FS project samples (e.g.. extraction procedure toxioity test. filters, byproducts of spill cleanups) will be collected, segregated, classified, packaged, and certified by the laboratory. The laboratory will then ship the waste packages to ORNL in accordance with DOT regulations (Subchapter C of Title 49 of the Code of Federal Regulations). The BNI GCO is responsible for inspecting incoming waste packages for conformance to ORNL waste treatment/storage/disposal acceptance criteria, the provisions of this plan and its implementing procedures, and DOT regulations. The laboratory will be issued a Nonconformance Report in arcordance with Project Procedure 1305, "Nonconformances," for nonconforming shipments or packages. Nonconforming waste packages will be repackaged as may be necessary to meet the ORNL waste acceptance criteria. All other types of waste generated by off-site laboratories, as a result of processing RI/ES project samples, will be dispored in accordance with the laboratory's permits and licenses.

\subsection{SOLID WASTE PACKAGING AND CERTIFICATION}

Solid wastes will be packaged and certifled in accordance with ORNL waste management procedures and ORNL RI/FS project procedures 
(Subsection 4.4). The following subsections summarize solid waste categories and procedures.

\subsubsection{Category 1: Low-Range Compactible LLW}

Category 1 wastes will be collected in yellow garbage cans equipped with plastic bag liners and tight-fitting lids. When a garbage can has been filled, or when a field activity at a specific investigation location has been completed, the bag will be securely taped closed.

ORNL FOrm UCN-2785 ("Radiation Hazard" tag) will then be properly completed and securely affixed to the bag. The bag will be placed in a yellow dumpster, and the appropriate line on ORNL Form UCN-16114 ("Log-In Data Sheet for Generators of LLW") will be filled out in accordance with RI/FS Project Procedure 1402 .

BNI certification of Category 1 waste packages will be accomplished by the GCO, whose signature will appear in the Note 3 line (Package Preparation Certification) on ORNL Form UCN-16114.

When the dumpster is full, the GCO will complete the approprtate portions of ORNL Form UCN-2822 ("Request for storage or Disposal of Radioactive solid Waste or special Materials") and notify the FSS Manager (or in his absence, the Energy systems Field Coordinator) that the dumpster is ready for transport.

\subsubsection{Category 2: Low-Range Noncompactible LLW}

Category 2 wastes will be collected in sealable containers (e.g., plastic containers, metal cans, DOT specificaticn $17 \mathrm{H}$ drums, or boxes). Category 2 waste packages will be posted with a properly completed ORNL Form UCN-2785 tag and placed inside a DOT specification $17 \mathrm{H}$ container. In some cases, such as when an item is too large to fit in an approved container and cannot be decontaminated to acceptable limits, items will be wrapped in plastic, taped securely closed, and posted with a properly completed 
ORNL Form UCN-2785. In either case, the item or container will have an assoolated, properly completed ORNL Form UCN-16114.

When a DOT specification $17 \mathrm{H}$ container has been filled to capacity and properly closed (in accordance with project procedure 1402), a properly completed ORNL Form UCN-2785 will be consplouously posted on the container. The GCO will then complete the approprlate portione of ORNL Form UCN-2822 and notify the FSS Manager that the container is ready for transport to the solid waste storage Area (SWSA).

BNI certification of Category 2 waste packages will be accomplished by the GCO's signature in the Note 3 certiflcation line of ORNL Form UCN-16114.

\subsubsection{Category 3: High-Range LLW}

Category 3 wastes will be packaged in metal containers (e.g., cans, drums, boxes) appropriately sized for the volume of waste. These containers will be posted with properly completed ORNL Form UCN-2785 and placed inside a bottom discharge biological shield (cask). Each container will be equipped with a rope or wire to facilitate its being lowered from the cask. Each cask will have an associated and properly completed ORNL Form UCN-16114 and will be posted with a properly completed ORNL Form UCN-2785 tag. The GCO will complete the appropriate portions of ORNL Form UCN-2822 and notify the FSS Manager that the cask is ready for transport to the SWSA.

BNI certiflcation of Category 3 waste packages will be accomplished by the GCO's signature in the Note 3 certification line of ORNL Form UCN-16II4.

\subsubsection{Category 4: High-Range LLW (Special Case)}

Packaging and disposal of Category 4 waste will require that special arrangements be made with the SWSA supervisor. Such arrangements will be made through the Energy systeme field coordinator by the FsS 
Manager, or in his absence, the GCO. The GCO will be responsible for ensuring that ORNL Forms UCN-2785, UCN-2822, and UCN-16114 are properly completed and that the appropriate certification is executea.

\subsubsection{Category 5: U-235 Waste}

Category 5 waste will be packaged in a sealed container and posted with a properly completed ORNL Form UCN-2785. The appropriate portions of ORNL Forms UCN-16114 and UCN-2681 (ORNL Nuclear Materials Intra-Laboratory Transfer) will then be completed. The container is then placed inside a DOT specification $17 \mathrm{H}$ container. When this container is filled to capacity, it will be closed in accordance with Project Procedure 1402 and will be conspicuously pasted with a properly completed ORNL Form UCN-2785. The GCO will then complete the appropriate portions of ORNL Form UCN-2822 and notify the FSS Manager that the container is ready for transport to the SWSA. The GCO will also advise the FSS Manager that written approval of the criticality Committee and the office of Operational Safety is required. The FSS Manager will coordinate these approvals through the Energy systems Field Coordinator.

BNI certification of Category 5 waste packages will be accomplished by the GCO's dated signature in the Note 3 certification line of ORNL Form UCN-16114 and in the Material Balance Area Representative's signature block of ORNL Form UCN-268l.

\subsubsection{Category 6: Suspect LLW}

Category 6 wastes will usually result from facility construction, alteration, demolition, or field excavations. The packaging and certification of suspect waste soils is addressed in subsections 6.5.25 through 6.5.27. Other Category 6 wastes will be packaged in containers (e.g., plastic containers, metal cans, dumpsters, dump trucks) sized for the volume of waste accumulated or anticipated. Each such container will be conspicuously posted with a properly completed ORNL Form UCN-2491 ("Health Physics Restriction Tag") or 
"Brown Tag." The GCO will ensure that the appropriate portions of ORNL Form UCN-16114 are completed for each such package or container. When the container has been filled to capacity, the GCO will complete the appropriate portions of ORNL Form UCN-2822 and notify the FSs Manager that the container is ready for transport to the SWSA.

BNI certification of Category 6 waste packages will be accomplished by the GCO's signature in the Note 3 certification line of ORNL Form UCN-16114.

\subsubsection{Category 7: Radioactive Asbestos Waste}

Category 7 wastes will be packaged in polyethylene bags at least $0.2 \mathrm{~mm}$ thick with a double-sealed bottom seam. Each such bag will be taped securely closed and placed bottom side up inside a second bag of the same specifications. The second bag will be taped securely closed and conspicuously posted with a properly completed ORNL Form UCN-2785 and an ORNL Form UCN-10781 (asbestos "Caution" tag). Double-bagged Category 7 waste packages may be placed inside DOT Specification $17 \mathrm{H}$ containers, either because of radioactive materials content or because of excessive weight.

Upon completion of packaging, the GCO will ensure that the appropriate portions of ORNL Form UCN-16114 have been properly completed. The GCO will then complete the appropriate portions of ORNL FOrm UCN-2822 and ORNL Form Number UCN-13386 ("Request for the Disposal of Asbestos or Material Containing Asbestos") and will then notify the FSS Manager that the package/container is ready for transport to the SWSA. The GCO will also notify the FSS Manager that review and approval by the ORNL Environmental Monitoring and Compliance (EMC) Department is required. The FSS Manager will coordinate the EMC Department review with the Energy Systems Field coordinator. 
BNI certification of Category 7 waste packages will be accomplished by the GCO's signature in the Note 3 certification line of ORNL Form UCN- 26214 and in the Requester's signature block of ORNL Form UCN-13386.

\subsubsection{Cateqory 8: Contact-Handled TRU Waste}

Category 8 waste always will be packaged in sealable containers inside DOT or DOE Type A stainless steel containers obtained from the ORNL SWSA [e.g., 30-gal drum, 55-gal drum, or for special cases only DOE Type A box (e.g., $6.2 \times 4.2 \times 3.2 \mathrm{ft} ; 5.7 \times 4.5 \times 3.2 \mathrm{ft}$ )]. The fissionable material content of these containers, as determined by laboratory analysis of a representative sample, shall not exceed: $100 \mathrm{~g} / 30$-gal drum; $200 \mathrm{~g} / 50$-gal drum; or $350 \mathrm{~g} / \mathrm{DOE}$ Type A box.

A properly completed ORNL Form UCN-2785 will be conspicuously posted on each interior package and on the outside of each Type $A$ ccntainer. The GCO will ensure that the appropriate portions of the ORNL "Log-In Data Sheet-Transuranic (TRU) Waste Generation" form are properly completed for each interior package. When a Type $A$ container has been filled to capacity, the GCO will complete the appropriate portions of ORNL Form UCN-2822 and, if fissionable materials and/or nuclear materials are present in combined quantities exceeding $5 \mathrm{~g}$, ORNL Form UCN-268l. The GCO will then notify the FSS Manager that the container must be processed through the Waste Examination Assay Facility (WEAF) and that, if more than $5 \mathrm{~g}$ of fissile and/or nuclear materials are present, review and approval is required by the ORNL Office of Operational safety and the criticality Comittee. The FSS Manager will coordinate these reviews and examinations through the Energy systems Field coordinator

BNI certification of Category 8 waste packages will be accomplished by the GCO's signature in the Note 3 certification line of the ORNL "Log-In Data Sheet-Transuranic (TRU) Waste Generation" form and, if necessary, in the Material Balance Area Representative's signature 5loch of CRav Fozm UCiv-2681. 


\subsubsection{Category 9: Remote-Handled TRU Waste}

Category 9 wastes will be packaged and certified exactly as required for Category 8 wastes except that individual waste packages will be placed in a special TRU waste cask obtained from the ORNL SWSA, provided the fissionable material content does not exceed 1 Ib per cask. Alternatively, Category 9 wastes properly packaged in DOT Type A drums ( $30 \mathrm{gal}$ and/or 55 gal DOT specification $17 \mathrm{H}$ stainless steel) will be placed in remotely handled Type A canisters obtained from the ORNL SWSA, provided that the fissionable material content does not exceed 1.3 lb per canister.

\subsubsection{Category 10: Characteristic Hazardous Waste}

Category 10 waste will be packaged in DOT specification 17H 30-gal or 55-gal, open-top drums obtained from the ORNL SWSA. The GCO Will ensure that a properly completed ORNL Form UCN-14 ("Health Physics Material Transfer Clearance," or "Green Tag") is conspicuously and securely posted on the DOT specification $17 \mathrm{H}$ drum. The GCO will also ensure that the appropriate portions of the ORNL "Log sheet for Hazardous Waste" form and ORNL Form UCN-13698 ("Request for Disposal of Hazardous Waste Material") are properly completed. The GCO will then notify the FSS Manager that the drum is ready for transport. The GCO will also notify the FSS Manger that review and approval is required by the ORNL Hazardous Waste Supervisor. The Fss Manager will coordinate this review through the Energy systems field Coordinator.

BNI certification of Category 10 waste packages will be accomplished by the GCO's signature in the INITIALS column of the ORNL "Log sheet for Hazardous Wasten form.

\subsubsection{Category 11: Listed Hazardous Waste}

Category 11 wastes will be packaged and certified exactly as required for Category 10 wastes. 


\subsubsection{Category 12: Characteristic and Listed Hazardous Waste}

Category 12 wastes will be packaged and certified exactly as required for Category 10 wastes.

\subsubsection{Category 13: LLW Mixed Characteristic Waste}

Category 13 wastes will be packaged in accordance with the requirements of subsections 6.5 .10 and 6.5 .1 through 6.5.4. Where packaging requirements conflict, the more restrictive requirements will apply. The ultimate packaging of category 13 wastes exhibiting greater than $2 \mathrm{mSv} / \mathrm{h}$ will require that special arrangements be made with the ORNL Hazardous Waste Supervisor. The FSS Manager will be responsible for coordinating these arrangements with the Energy systems Field coordinator.

The GCO will ensure that properly completed ORNL Forms UCN-2785 are conspicuously and securely posted on both the interior packages and the outer container. When an outer container has been filled to capacity, the GCO will ensure that the appropriate portions of the ORNL "Log sheet for Hazardous Waste" form have been completed. The GCO will then complete the appropriate portions of ORNL Form UCN-13698 and notify the FSS Manager that the container is ready for transport. The GCO will also notify the FSS Manager that review and approval is required by the ORNL Hazardous Waste supervisor. The FSS Manager will coordinate this review through the Energy systems Field Coordinator.

BNI certification of Category 13 waste packages will be accomplished by the GCO's signature in the INITIALS column of the ORNL "Log sheet for Hazardous Waste".

\subsubsection{Cateqory 14: LLW Mixed Listed Waste}

Category 14 wastes will be packaged and certified exactly as required for Category 13 wastes. 


\subsubsection{Category 15: LLW Mixed Characteristic and Listed Waste}

Category 15 wastes will be packaged and certified exactly as required for Category 13 wastes.

\subsubsection{Category 16: TRU Mixed Waste}

Category 16 wastes will be packaged in accordance with the requirements of subsections $6.5 .8,6.5 .9$, and 6.5.10. Where packaging requirements conflict, the more restrictive reçuirements will apply. The ultimate packaging of Category 16 wastes exhibiting greater than $2 \mathrm{mSv} / \mathrm{h}$ will require special arrangements with the ORNL Hazardous Waste Supervisor. The FSS Manager will be responsible for coordinating these arrangements with the Energy systems Field Coordinator.

The GCO will ensure that properly completed ORNL Forms UCN-2785 are conspicuously and securely posted on both the interior packages and the outer container. The GCO will also ensure that the appropriate portions of the ORNL "Log-In Data Sheet-Transuranic (TRU) Waste Generation" form are properly completed for each waste pacxage. When the waste container has been filled to capacity, the GCO will complete the appropriate portions of ORNL Forms UCN-2822 and UCN-2681 in accordance with Project Procedure 1402, noting that the contents include hazardous as well as TRU wastes. The GCO will then notify the FSS Manager that the container is ready for transport to the WEAF. The GCO will also notify the FSS Manager that if more than $5 \mathrm{~g}$ of combined fissionable and nuclear materials are present, review and approval is required by the ORNL office of operational Safety and Criticality Comittee. The FsS Manager will coordinate these reviews and examinations through the Energy systems Field Coordinator.

BNI certification of Category 16 waste packages will be accomplished by the GCO's dated signature in the Note 3 certification line of the ORNL "Log-In Data Sheet-Transuranic (TRU) Waste Generation" form and, if necessary, in the Material Balance Area Representative's

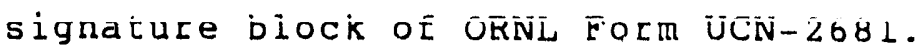




\subsubsection{Category 17: LLW Exception Mixed Characteristic Waste}

Category 17 wastes will be packaged in accordance with the requirements of subsections 6.5 .5 and 6.5.10. When packaging requirements conflict, the more restrictive requirements will apply. The GCO will ensure that properly completed ORNL Form UCN-2785 is conspicuously and securely posted on both the interior packages and the outer container.

When the outer container has been filled to capacity, the GCO will ensure that the appropriate portions of the ORNL "Log sheet for Hazardous Waste" form have been completed for each waste package. The GCO will then complete the appropriate portions of ORNL Forms UCN-2681 and UCN-13698 and notify the FSS Manager that the container is ready for transport to the SWSA. The GCO will also notify the FSS Manager that reviews and approvals are required by the ORNL Hazardous Waste Group Leader, Criticality Committee, and office of Operational safety. The Fss Manager will coordinate these reviews through the Energy systems Field Coordinator.

BNI certification of Category 17 waste packages will be accomplished by the GCO's signature in the "INITIALS" column of the ORNL "Log Sheet for Hazardous Waste" form and in the Material Balance Area Representative's signature block of ORNL Form UCN-2681.

\subsubsection{Category 18: LLW Exception Mixed Listed Waste}

Category 18 wastes will be packaged and certified exactly as required for Category 17 wastes.

\subsubsection{Cateqory 19: LLW Exception Mixed Characteristic and Listed Waste}

Category 19 wastes will be packaged and certified exactly as required for Category 17 wastes. 


\section{5 .20 Category 20: TSCA Waste}

Category 20 wastes will always be packaged in DOT specification $17 \mathrm{H}$ 30-gal or 55-gal drums. When a drum has been filled to capacity. the GCO will ensure that an ORNL Form UCN-14 has been properly completed and conspicuously and securely posted on the drum. The GCO will also complete the appropriate portions of ORNL Form UCN-13698. The GCO will then notify the FSS Manager that the drum is ready for transport and that review and approval is required by the ORNL Hazardous Waste supervisor. The FSS Manager will coordinate this review through the Energy systems Field Coordinator.

BNI certification of Category 20 waste packages will be accomplished by the GCO's signature in the "Waste Generator" block of ORNL Form UCN-13698.

\subsubsection{Category 21: Radioactive TSCA Waste}

Category 21 wastes will be packaged in accordance with the requirements of subsections 6.5 .20 and 6.5 .1 through 6.5.7. as appropriate for the radioactive materials content or the radiation levels. Where packaging requirements conflict, the more restrictive requirements will apply. The ultimate packaging of Category 21 wastes exhibiting greater than $2 \mathrm{mSv} / \mathrm{h}$ will require special arrangements with the ORNL Hazardous Waste supervisor. The FSS Manager will be responsible for coordinating these arrangements with the Energy Systems Field Coordinator.

The GCO will ensure that properly completed ORNL Forms UCN-2785 are conspicuously and securely posted on the interior packages and the outer container. When the outer container has been filied to capacity, the GCO will ensure that all appropriate orNL forms are completed, depending on radioactive material content and radiation levels. Completion of the appropriate portion of ORNL Form UCN-13698 will be the required minimum level of documentation. 
BNI certiflcation of Category 21 waste packages will be accomplished in accordance with subseations 6.5 .20 and 6.5 .1 through 6.5.7, as appropriate for the radioactive materials vontent of the package.

\subsubsection{Category 22: Disposable Conventional Waste}

Category 22 wastes will be placed direotly into green dumpsters located on the RI/FS project field operations facility site or will be transported directly to the $Y-12$ sanitary Landfill, depending on the type and quantity of waste involved. Routine contamination surveys will be performed of the dumpster and its immediate environment and the bulk shipments to the $Y-12$ sanitary Landeill to ensure the absence of radioactive and/or hazardous chemical contaminants.

The FHS supervisor will ensure that a final contamination survey is performed on Category 22 wastes prior to their removal for disposal and that a properly completed ORNL Form UCN-14 is conspicuously and securely posted on the dumpster or truck. The FHs supervisor will ther notify the FSS Manager that the wastes are ready for disposal. The Fss Manager will coordinate the disposal with the ORNL Plant and Equipment (P\&E) Division through the Energy systems Field Coordinator.

\subsubsection{Category 23: Scrap Metal Waste}

Category 23 waste materials will be surveyed for radioactive and, if necessary, hazardous chemical contaminants. Items having contamination levels less than the limits specified in subsection 6.3.2.1 will be conspicuously and securely posted with a properly completed ORNL Form UCN-14 and then placed in bins. When a bin has been filled to capacity, the FSS Manager will request a final contamination survey. The FHS supervisor will ensure that a properly completed ORNL Form UCN-14 is conspicuously and securely posted on the bin. The F's Manager will then coordinate through the Frergy systems Field Coordinator for pickup of the bin by the ORNL P\&E Division. 


\subsubsection{Category 24: Reayclable Waste}

Category 24 waste materials will be collected, surveyed, and disposed in accordance with the requirements of subsection 6.5 .23 .

\subsection{SOIL HANDLING CRITERIA}

Waste soll generated by ORNL RI/FS project driliting and/or excavation activities will be handled and disposed in accordance with the ORNL "Health, Safety, and Environmental protection Procedures for Excavating Operations" (Attachment C). Categories and appropriate actions are summarized in the following subsections.

\subsubsection{Category I Soils}

Category I soils are considered to be uncontaminated, and as such, will be used for backfill or disposed in the Y-12 sanitary Landfill. The GCO will ensure that containers or vehicles used for transportation of Category I solis are conspicuously and securely posted with a properly completed ORNL Form UCN-14. The FsS Manager will be responsible for coordinaring disposal of Category I soils with the Energy systems Field Coordinator.

\subsubsection{Category II Soils}

Category II solis may be used for limited backfill at the site of origin or in a contaminated zone (of similar radiation levels) that is remote from human occupation. Field emplacement of category II soils will be covered with at least $30 \mathrm{~cm}$ of uncontaminated soil. The GCO will ensure that containers or vehicles used to transport Category I soils from the site of origin to the backfill location are conspicuously and securely posted with a properly completed orNL Form UCN-2491. The F'SS Manager will coordinate backill operations involving Category I soils with the Energy systems Field Coordinator. 
Packagling and certification of Category II solls not needed for backeill will be accomplished in accordanoe with the requirements of Subsection 6.5 .2 (Category 2 solid waste).

\subsubsection{Category III Sol1s}

Category II solis or solis contaminated with hazardous chemicals in excess of the limits detailed in Table 6-4 will be handled in compliance with the requirements of the appropriate sections of Subsection 6.5 , depending on contaminant type, contaminant concentration, or radiation levels.

\subsection{LIOUID WASTE PACKAGING AND CERTIEICATION}

Liquid waste will be packaged and certified in accordance with ORNL waste management procedures and ORNL RI/FS project procedures (Bee subsection 4.4), as summarized in the following subsections.

\subsubsection{Category 1: Process Waste Treatment Plant (PWTP) Waste}

Category 1 wastes will be collected in containers convenient for the operation producing the waste (e.g., mud tanks, bladder tanks) and may be transferced to transportable tanks or DOT specification $17 \mathrm{E}$ 55-gal drums for transportation to the PWTP. The GCO will ensure that a properly comeleted ORNL Form UCN-2785 is conspicuously and securely pusted on the container used to transport the waste. The GCO will be responsible for ensuring that the ORNL RI/FS project "Disposal of Radioactive Liquid Waste Certification Form" is properly completed in a timely fashion. The Fss Manager will be responsible for coordinating arrangements for disposal with the Energy systems Field Coordinator.

BNI certification of Category I waste will be accomplished by the GCO's dated signature on the "Person Certifying Analysis" line of the ORNL RI/FS project "Disposal of Radioactive Liquid Waste Form" in accordance with the requirements of RI/ES Project Procedure 1402. 


\section{7 .2 Category 2: Low-Level Liquid Waste}

Category 2 wastes will be packaged and gertified exactly as regutred for Category I wastes.

\subsubsection{Category 3: TRU Liguid Waste}

Category 3 wastes will be packaged and certified exactly as required for Category 2 wastes.

\subsubsection{Category 4: Characteristic Hazardous Liquid Waste}

Category 4 wastes will be collected in DOT specification 17E 55-gal drums for ignitable, reactive, or EP toxicity wastes, and in DOT specification 6D 55-gal drums for corrosive wastes. The GCO will ensure that a properly completed ORNL Form UCN-14 is conspicuously and securely posted on the drum, that the appropriate portions of ORNL Form UCN-13698 are properly completed, and that a "Certifled Chemical Analysis" is attached to the UCN-13698 form. The GCO will then notify the FSS Manager that the drum is ready for transportation. The FSS Manager will coordinate with the ORNL Hazardous Waste Supervisor for the transportation or pickup of Hazardous Chemical and Mixed Wastes through the Energy systems Fleld Coordinator.

BNI certification of Category 4 waste will be accomplished by the GCO's signature in the "Waste Generator" block of ORNL Form UCN-13698.

\subsubsection{Category 5: Listed Hazardous Liquid Waste}

Category 5 wastes will be packaged and certified exactly as required for Category 4 wastes. 


\subsubsection{Category 6: Characteristio and Listed Hazardous Liquid Waste}

Category 6 wastes will be packaged and certifled exactly as required for Category 4 wastes.

\subsubsection{Category 7: Mixed PWTP Waste}

Category 7 waste will be packaged and certified exactly as required for Category 4 wastes, except that the GCO will ensure that a properly completed ORNL Form UCN-2785 (1nstead of UCN-14) is conspicuously and securely posted on the drum.

\subsubsection{Category 8: Mixed Low-Level Liquid Waste}

Category 8 waste will be packaged and certified exactly as required for Category 4 wastes, except that the GCO will ensure that a properly completed ORNL Form UCN-2785 (instead of UCN-14) is conspicuously and securely posted on the drum.

\subsubsection{Category 9: Mixed TRU Liquid Waste}

Category 9 waste will be packaged and certified exactly as required for Category 4 wastes, except that the GCO will ensure that a properly completed ORNL Form UCN-2785 (instead of UCN-14) is conspicuously and securely posted on the drum.

\subsubsection{Category 10: TSCA Liquid Waste}

Category 10 waste will be collected in DOT specification 17E 55-gal drums, posted and certified as required by subsection 6.7 .4 (Category 4 waste). 


\subsubsection{Category 11: Radioautive TSCA Liquid Waste}

Category 11 waste will be completed in DOT specification 17E 55-gal drums, conspiouously and securely posted with a properly completed ORNL Form UCN-2785 and certified as required for Category 4 wastes.

\subsubsection{Category 12: Uncontaminated Liquid Waste}

Category 12 wastes will be collected in containers convenient for the operations producing the waste and may be transferced to transportable tanks, tanker trucks, or DOT specification 17E 55-gal drums for transportation to the disposal location. The GCO will ensure that a properly completed oRNL Form UCN-14 is conspicuouly and securely posted on the container. The Fss Manager will be responsible for coordinating disposal with the Energy systems Field Coordinator. The FSS Manager will be responsible for ensuring that approval of the ORNL EMC section is obtained prior to disposal. The FSS Manager will coordinate the EMC section review through the Energy Systems Field Coordinator.

\subsubsection{Category 13: Sanitary Liquid Waste}

Category 13 waste will be discharged into an ORNL-approved septic tank system installed on the RI/FS project field operations facility site. If Category 13 wastes are encountered during RI/FS field activities, they will be collected in transportable tanks or tanker trucks. The GCO will ensure that a properly completed ORNL Form UCN-14 is conspicuously and securely posted on the tank. The Fss Manager will be responsible for coordination of disposal of the Category 13 wastes with the Energy systems Field Coordinator. Disposal will be at either the ORNL sewage Treatment plant, a septic Tank, or in a holding tank until such time that the waste can be pumped to a transfer truck and be disposed in an approved manner. 


\subsubsection{Category 14: Recyclable Oil}

Category 14 wastes will be collected in DOT specification 17E 55-gal drums. The GCO will ensure that each drum is conspicuously and securely posted with properly completed ORNL Forms UCN-14 and UCN-13698 ("Waste Oil/Oily Sludge"). The FSS Manager will be responsible for coordinating pickup of the drum with the Hazardous Waste Supervisor through the Energy systems Field coordinator.

\subsection{WASTE PACKAGE TRANSPORTATION}

Waste materials that exhibit contamination levels in excess of Table 6-2 limits, as determined by field measurement rechniques, or for which there is reason to suspect that they may be contaminated, will be contained and held until such time that laboratory analysis either confirms anc afines, or denies, the presence of contamination. In most cases, waste packages will be transported from the generation location to a location specified by Energy systems for interim storage. In some cases (e.g.. Category l solid wastes), estimates will be made of the radioactive materials' content and the waste packages transported directly to an interim collection point. In other cases (e.g.. Category 22 solid wastes, Category I soils), the waste may be transported directly to its Einal destination.

BNI will be responsible for transportation of waste packages from the point of collection to the Energy systems-specified interim storage area. locations specified for interim collection (e.g., dumpsters), and directly to final destination (e.g., laundry, $Y-12$ Sanitary Landfill). Transportation of waste packages from RI/FS project locations and facilities to ORNL waste treatment/storage/ disposal facilities will be accomplished by Energy systems.

For the purposes of transportation only, waste materials will be classified and handled in accordance with the following requirements. 


\section{8 .1 Solid Wastes}

Solid wastes will be transported in accordance with known or suspected content characteristics, as defined in the following subsections.

\subsubsection{Conventional and DOT Exempt Waste. Conventional waste} will be collected and contained as may be appropriate for material (e.g.. green dumpsters for refuse, dump trucks for Category 1 soils, bins for scrap metal and recyclable waste). BNI will transport conventional waste, via methods suitable for the collection containers, to designated disposal or pickup points. Other that the ORNL Form UCN-14 required by Paragraphs 6.5 .22 through 6.5 .24 and 6.6.1. the transportation of conventional waste will not require special labeling, placarding, or manifesting.

Waste materials that exhibit contamination levels in excess of Table 6-2 limits, but contain $7.4 \times 10^{4} \mathrm{~Bq} / \mathrm{kg}$ or less of total radioactivity, will be packaged in strong tight containers suitable for the materials to be transported (e.g., cloth or plastic bags for contaminated PPE, plastic bags for Category l solid wastes) or as may be required in section 6.5, whichever is more restrictive. Labeling of waste packages, placarding of transportation vehicles, and manifesting of shipments will not be required, except as provided for in section 6.5 .

6.8.1.2 Contact-Handled Waste. Waste materials that contain greater than $7.4 \times 10^{4} \mathrm{~Bq} / \mathrm{kg}$, and exhibit radiation levels at the unshielded package surface of $2 \mathrm{mSv} / \mathrm{h}$ or less, will be packaged at the point of collection as required in sections 6.5 and 6.6 . Waste packages in this category will be transported in exclusive use vehicles, in accordance with the provisions of Project Procedure 1403 .

On-site shipments that do not require the use of public highways will not require special labeling, placarding, or manifesting. except as required in section 6.5 . 
On-site shipments that require the use of public highways will be packaged in DOT specification containers as appropriate for the material (e.g., DOT Specification $17 \mathrm{H}$ or 6D, Type A drums) in accordance with the requirements of 49 CFR 173 and 49 CFR 178. Shipping containers will be labeled and marked in accordance with the requirements of 49 CFR 172.400 through 49 CFR 172 and 49 CFR 172.300 through 49 CFR 172.338 , respectively. The transportation vehicle will be placarded in accordance with the requirements of 49 CFR 172.500 through 49 CFR 172.558. Shipping papers for the shipment itself will be in accordance with the requirements of 49 CFR 172.200 through 49 CFR 172.205, using ORNL Form UCN-12301 (Oak Ridge National Laboratory Radioactive Materials Packaging Certification), if required. The GCO will be responsible for ensuring that required labeling, marking, and placarding are properly executed prior to shipment. The GCO also ensures that pertinent portions of ORNL Form UCN-12301 are properly completed and notifies the FSS Manager that the waste is ready for transport. The FSS Manager is responsible for ensuring that the RI/FS project waste package interim storage facility is notified of, and capable of accepting, the incoming shipment and for coordinating the shipment with the Energy Systems Field Coordinator. Detailed waste packaying and shipment requirements are contained in Project Procedures 1402 and 1403 .

Upon completion of the shipment, and prior to release of the transportation vehicle for unrestricted use, the FHs supervisor will ensure that the vehicle is surveyed for residual contamination. If residual contamination levels in excess of Table 6-2 limits are detected, the vehicle will be decontaminated in accordance with the provisions of Paragraph 6.3.2.

\subsubsection{Remote-Handled Waste. The FSS Manager will be} responsible for making arrangements with the Energy systems field Coordinator for delivery of an appropriate bottom discharge biological shield (cask) for waste packages exhibiting in excess of $2 \mathrm{mSv} / \mathrm{h}$ at the unshielded nackage surface. The chipmont will require that waste materials be packaged in DOT specification $17 \mathrm{H}$ 
30-gal or 55-gal drums to accommodate insertion into the cask. If the shipment requires the use of public highways, the GCO will be responsible for ensuring that radiation levels do not exceed $10 \mathrm{mSv} / \mathrm{h}$ at the cask's surface, $2 \mathrm{mSv} / \mathrm{h}$ at any external surface of the vehicle [or at any point on the vertical planes projected from the outer edge of the vehicle (for open vehicles)], and $0.1 \mathrm{mSv} / \mathrm{h}$ at 6.5 ft from any external surface (or vertical planes projected from the outer edge) of the vehicle. Labeling of the cask, placarding of the transportation vehicte, and manifesting and execution of the shipment will all be accomplished as specified in paragraph 6.8.1.2 for on-site shipments requicing the use of public highways.

6.8.1.4 Hazardous Waste. This category represents a special transportation case for shipments requiring the use of public highways. In this case, hazardous wastes will be packaged at the point of collection as required by section 6.5 , in compliance with 49 CFR Parts 172, 173, 177, 178, and 179. If the waste is a mixed waste, the most restrictive of the radioactive and hazardous materials packaging requirements will apply, and the GCO will be responsible for assuring that all the provisions of Paragraphs 6.8.1.1 through 6.8.1.3 have been complied with. For either hazardous or mixed waste packages, ORNL Form UCN-14352 ("Hazardous Waste Manifest") will be completed. The GCO is responsible for certifying the shipment by dated signature in the "Transporter Authorized Representative" blocks of ORNL Form UCN-14352. The FSS Manager is responsible for coordinating with the Energy systems Field Coordinator to obtain the required Energy systems certifying signatures on ORNL Form UCN-14352 and for transportation to the Energy Systems-specified interim storage area.

\section{8 .2 Liquid Waste}

Liquid waste will be transported in accordance with known or suspected content characteristics, as defined in the following subsections. 
6.8.2.1 Uncontaminated, Nonhazardous and DOT Exempt Waste. For the purposes of transportation only, this category includes uncontaminated liquid wastes (e.g., sanitary wastes, recyclable oil, those liquids that are not classifiable as RCRA or TSCA hazardous) and liquids containing $7.4 \times 10^{4} \mathrm{~Bq} / \mathrm{L}$ or less of total radioactivity. This category of waste will be collected in containers suitable for the type of material (e.g., mud tanks, holding tanks, drums) and transferced as may be appropriate to shipping containers. Shipping containers may include such vessels or vehicles as may be appropriate [e.g., truck mounted bladder tanks, DOT specification $17-E$ drums (for recyclable oil), tank trucks] that will provide safe and secure transportation. Except as required by section 6.7, special waste package labeling, transportation vehicle placarding, and shipment manifesting will not be required.

\subsubsection{Contact-Handled Waste. Liquid waste containing} radioactive materials in excess of a total activity of $7.4 \times 10^{4}$ $\mathrm{Bq} / \mathrm{L}$ and exhibit radiation levels at the unshielded container surface of $2 \mathrm{mSv} / \mathrm{h}$ or less will be packaged at the point of collection as required in section 6.7. Waste packages in this category will be transported in exclusive use vehicles, in accordance with the provisions of Project Procedure 1403.

Except as required in section 6.7, on-site shipments that do not require the use of public highways will not require special handing, labeling, marking, placarding, or manifesting. such shipments may use bulk transport vessels or containers (e.g., truck mounted bladder tanks, tank (rucks), if said containers provide for safe and secure transportation.

On-site shipments that require the use of public highways will be packagéd in DOT specification containers. This will normally require the use of DOT Specification 17E Type A drums. Bulk shipments may be made, however, if DOT specification $103 \mathrm{CW}$ or lilA60W7 tank cars/trucks are used. Shipping container labeling and 
marking, transportation vehicle placarding, and shipment manifesting will be executed in accordance with the requirements of paragraph 6.8 .1 .2 .

6.8.2.3 Remote-Handled Waste. In the remote-handled liquid waste (greater than 2 msv/h at the unshielded package surface) are generated by RI/FS project field activities, special arrangements for transportation will be made with Energy systems. The FSS Manager is responsible for making these arrangements with the Energy systems Field Coordinator. The GCO is responsible for ensuring that radiation levels, labeling, placarding, and manifesting comply with the requirements of section 6.7 and Paragraphs 6.8 .1 .2 and 6.8 .1 .3 .

\subsubsection{Hazardous Waste. This category represents a special} transportation case for shipments requiring the use of public highways. RCRA and/or TSCA hazardous liquids and mixed liquid wastes will always be packaged in DOT specification $17 \mathrm{E}$ or $6 \mathrm{D}$ drums as appropiate for the material. Except as required in section 6.7, on-site shipments not requiring the use of public highways will not require special labeling, placarding, or manifesting. If the waste is mixed waste, the GCO will be responsible for ensuring that all the provisions of Paragraphs 6.8.2.1 through 6.8.2.3 have been complied with. Labeling and marking of containers and placarding of the transportation vehicle will be executed in accordance with the requirements of sutparts $E$ and $F$, respectively, of 49 CFR 172. Manifesting of the shipment will be executed in accordance with the requirements of subpart C of 49 CFR 172, using ORNL Form UCN-14352. The GCO is responsible for certifying the shipment by dated signature in the "Transporter Authorized Representative" blocks of ORNL Form UCN-14352. The FSS Manager is responsible for coordinating with the Energy systems Field Coordinator to obtain the required Energy systems certifying signatures on ORNL Form UCN-14352 and for transportation to the Energy systems specified interim storage area. 


\subsection{RECORDS}

BNI will retain records of all waste management transactions, in the form of copies of each form utilized. In addition, BNI will generate and retain an independent record of each waste material transaction. These records may be generated and retained by either the Bechtel Bar Code system (BeCode) or by a manual system. In either case, records will provide for retention of the following minimum information:

- Container identification (used only if appropriate)

- Location at which the waste was generated ( $X, Y, \& Z$ coordinates)

- The date that the waste was removed from the ORNL RI/FS project work site

- The date that the waste was transferred to Energy systems' custody, or disposed of, if different than the generation date

- Principal isotopes and/or hazardous substances (by CAS and/or EPA Hazardous Waste number) or field measurement values

- Total activity or quantity based on laboratory analysis, or a "best estimate" of total activity based on field measurements

- Physical form of the waste material

- Destination to which the waste materia was transferred

- Person recieiving the waste

All such records will be maintained by BNI for the duration of the ORNL RI/FS project. At the completion of the project, BNI will provide Energy systems with copies of these records. 


\section{REFERENCES}

Bechtel National. Inc. Team. 1987a. Project Management Plan for the Oak Ridge National Laboratory Remedial Investigation/Feasibility Study. ORNL/RAP/Sub-87/99053/1. Oak Ridge, Tennessee.

Bechtel National. Inc. Team. 1987b. Environmental, Safety and Health Plan for the Oak Ridge National Laboratory. ORNL/RAP/Sub-87/99053/3. Oak Ridge, Tennessee.

Huang, S. F., W. A. Alexander, J. B. Watson, and T. W. Oakes. 1984. Preliminary Radiological Survey of the Gunite Waste Tanks in the South Tank Farm at ORNL. ORNL/CF-84/206. Oak Ridge National Laboratory, Oak Ridge, Tennessee.

Oak Ridge National Laboratory. 1986. Safety Assessment - Equipment Cleaning Facility. Building 7935. ORNL/ENG/SA-13447. Oak Ridge National Laboratory, Oak Ridge, Tennessee.

Oak Ridge National Laboratory. 1987. Remedial Investigation Plan for the Subsurface Characterization of the ORNL Hydrofracture Sites. ORNL/RAP-7. Oak Ridge National Laboratory, Oak Ridge, Tennessee.

Oakes, T. W. et al. 1987. Environmental surveillance of the U.S. Department of Energy Oak Ridge Reservation and Surrounding Environs During 1986. ES/ESH-I/VI. Oak Ridge National Laboratory, Oak Ridge, Tennessee.

Peretz, F. J., B. R. Clark, C. B. Scott, and J. B. Berry. 1986. Characterization of Low-Level Liquid Wastes at the Oak Ridge National Laboratory. ORNL/TM-10218. Onk Ridge National Laboratory, Oak Ridge, Tennessee. 
ATTACHMENT A

CHARACTERISTICS OF A HAZARDOUS WASTE 
ATTACHMENT A

CHARACTERISTICS OF A HAZARDOUS WASTE

A solid waste is defined as a hazardous waste in subpart $C$ of 40 CFR 261 if it exhitits any of the characteristics listed and defined below.

\section{CHARACTERISTIC OF IGNITABILITY (40 CFR 261.21)}

A solid waste exhibits the characteristic of ignitability if a representative samplo of the waste has any of the following properties:

- It is a liquid other than an aqueous solution containing less than 24 percent alcohol by volume and has a flash point less than $60^{\circ} \mathrm{C}$ is determined by a Pensky-Martens Closed Cup Tester, using the test method specified in ASTM standard D-93-79 or D-93-80; or a setaflash Closed Cup Tester, using the test method specified in ASTM standard D-3278-78.

- It is not a liquid and is capable, under standard temperature and pressure, of causing fire through friction, absorption of moisture, or spontaneous chemical changes; and when ignited, burns so vigorously and persistently that it creates a hazard.

- It is an ignitable compressed gas as defined in $49 \mathrm{CFR}$ 173.300 and as determined by the test methods described in that regulation.

- It is an oxidizer as defined in 49 CFR 173.151.

A solid waste that exhibits the characteristic of ignitability, but is not 1 isted as a hazardous waste in subpart $D$ of 40 CFR 261

(Attachment $B$ ), has the EPA Hazardous Waste Number of Dool.

\section{CHARACTERISTIC OF CORROSIVITY (40 CFR 261.22)}

A soliu waste exhibits the characteristic of corrosivity if a representative sample of the waste has either of the following properties: 
- It is aqueous and has a pH less than or equal to 2 or greater than or equal to 12.5 , as determined by a pH meter using EPA Test Method 5.2, as specified in "Test Methods for the Evaluation of Solid Waste. Physical/Chemical Methods $(S W-846) . "$

- It is a liquid and corrodes SAE 1020 steel at a rate greater than $6.35 \mathrm{~mm}$ per year at a test temperature of $55^{\circ} \mathrm{C}$, as determined by the test method specified in National Association of Corrosion Engineers (NACE) Standard TM-01-69; and as standardized in "Test Methods for the Evaluation of Solid Waste, Physical/Chemical Methods (SW-846)."

A solid waste that exhibits the characteristic of corrosivity, but is not listed as a hazardous waste in subpart D of 40 CFR 261 (Attachment B), has the EPA Hazardous Waste Number or D002.

\section{CHARACTERISTIC OF REACTIVITY (40 CFR 261.23)}

A solid waste exhibits the characteristic of reactivity if a representative sample of the waste has any of the following properties:

- It is normally unstable and readily undergoes violent change without detonation.

- It reacts violentiy with water.

- It forms potentially explosive mixtures with water.

- When mixed with water, it generates toxic gases, vapors, or fumes in quantities sufficient to present a danger to human health or the environment.

- It is a cyanide or sulfide-bearing waste that, when exposed to $\mathrm{pH}$ conditions between 2 and 12.5 , can generate toxic gases, vapors, or fumes in a quantity sufficient to present a danger to human health and the environment.

- It is capable of detonation or explosive reaction if subjected to a strong initiating source or if heated under confinement.

- It is readily capable of detonation or explosive decomposition or reaction at standard temperature and pressure. 
- It is a forbidden explosive as defined in 49 CFR 173.51, or a Class A explosive as defined in 49 CFR 173.53, or a Class $B$ explosive as defined in 49 CFR 173.88.

A solid waste that exhibits the characteristic of reactivity, 'but is not 1 isted as a hazardous waste in subpart $D$ of 40 CFR 261 , has the EPA Hazardous Waste Number of D003.

\section{CHARACTERISTIC OF EP TOXICITY (40 CFR 261.24)}

A solid waste exhibits the characteristic of EP toxicity if, using the test methods described in "Test Methods for the Evaluation of Solid Waste, Physical/Chemical Methods (SW-846)," the extract froma representative sample of the waste contains any of the contaminants listed in Table A-1 at a concentration equal to or greater than the values given in that table. Where the waste contains less than 0.5 percent filterable solids, the waste itself, after filtering, is considered to be the extract.

A solid waste that exhibits the characteristic of EP toxicity, but is not listed as a hazardous waste in subpart $D$ of 40 CFR 261

(Attachment B), has the EPA Hazardous Waste Number that corresponds to the toxic contaminant causing it to be hazardous, as specified in Table A-1. 
TABLE A-1

MAXIMUM CONCENTRATION OF CONTAMINANI'S FOR CHARACTERISTIC OF EP TOXICITY

\begin{tabular}{llr}
\hline $\begin{array}{c}\text { EPA } \\
\text { Hazardous } \\
\text { Waste No. }\end{array}$ & Contaminant & $\begin{array}{c}\text { Maximum } \\
\text { Concentration } \\
\text { (mg/L) }\end{array}$ \\
\hline D004 & Arsenic & 5.0 \\
D005 & Barium & 100.0 \\
D006 & Cadmium & 1.0 \\
D007 & Chromium & 5.0 \\
D008 & Lead & 5.0 \\
D009 & Mercury & 0.2 \\
D010 & Selenium & 1.0 \\
D011 & Silver & 5.0 \\
D012 & Endrin & 0.02 \\
D013 & Lindane & 0.4 \\
D014 & Methoxychlor & 10.0 \\
D015 & Toxaphene & 0.5 \\
D016 & 2,4-D & 10.0 \\
D017 & 2,4,5-TP (Silvex) & 1.0 \\
& & \\
\hline
\end{tabular}


ATTACHMENT B

LISTS OF HAZARDOUS WASTES

$B-1$ 


\section{ATTACHMENT B \\ LISTS OF HAZARDOUS WASTES}

A solid waste is classified as hazardous if it is on any of the lists included herein as Tables B-1 through B-4. For each table, classes and types of hazardous waste are assigned one of the folluwing Hazard Codes:

\author{
Ignitable Waste \\ Corcosive Waste \\ Reactive Waste \\ EP Toxic Waste \\ Acute Hazardous Waste \\ Toxic Waste
}

( I )

(C)

(R)

(E)

(H)

( $\mathrm{T}$ ) 
TABLE B-1

HAZARDOUS WASTES FROM NONSPECIFIC SOURCES

(40 CFR 261.32)

Industry and EFA

Hazardous Waste No.
Hazardous Waste

Hazard

code
F019

F007

F008

F009

F010

F011

$F 012$

F024

$F 020$

F021

F022

$F 023$

$F 026$

F027

F028

Wastewater treatment sludges from the chemical conversion coating of aluminum.

Spent cyanide plating bath solutions from electroplating operations.

plating bath restdues from the bottom of plating baths from electroplating operations where cyanides are used in the process.

Spent stripping and cleaning bath solutions from electroplating operations where cyantdes are used in the process.

Quenching bath restdues from oif baths from metal heat treating operations where cyanides are used in the process.

spent cyanide solutions from salt bath pot cleaning from metal heat treating operations.

Quenching waste water treatment sludges from metal heat treating operations where cyantdes are used in the process.

Wastes, including but not 1 imited to, distillation residues, heavy ends, tars, and reactor clean-out wastes from the production of chlorinated aliphattc hydrocarbons, having carbon conterit from one to $f$ ive, uttlizing free radical catalyzed processes. (This 1 tsting does not include light ends, spent filters and filter aids, spent dessicants, wastewater, wastewater treatmen' siudges, spent catalysts, and wastes 1 isted in $\$ 261.32$.)

Wastes (except wastewater and spent carbon from hydrogen chloride purification) from the production or marlufacturing use (as a reactant. chemical intermediate, or component in a formulating process) of trior tetrachloropheno1, or of intermediates used to produce thetr pesticide derfvatives. (This listing does not include wastes from the production of Hexachlorophene from highly purified 2,4,5trichlorophenol.)

Wastes (except wastewater and spent carbon from hydrogen chloride purification) from the manufacturing use (as a reactant, chemical intermediate, or component in a formulating process) of pentachlorophenol, or of intermediates used to produce its derivatives.

Wastes (except wastewater and spent carbon from hydrogen chloride purification) from the manufacturing use (as a reactant. chemical intermediate, or component in a formulating process) of tetra-, penta-, or hexachlorobenzenes under alkaline conditions.

wastes (except wastewater and spent carbon from hydrogen chloride jurification) from the production of materials or equipment previously used for the production or manufacturing use (as a reactant. chemical intermediate, or component in a formulating process) of tri- and tetrachlorophenols. (This 1 isting does not include wastes from equipment used only for the production or use of Hexachlorophene from highly purified 2,4,5-trichiorophenol.).

Wastes (except wastewater and spent carbon from hydrogen chioride puri. fication) from the production of materials or equipment previously used for manufacturing use (as a reactant, chemical intermediate. or component in a formulating process) of tetra-, penta-, or hexachiorobenzene under alkal ine conditions.

Discarded unused formulations containing tri-, tetra-, or pentachlorophenol or discarded unused formulations containing :ompounds derived from these chlorophenols. (This 1 isting does not include formulations containing Hexachlorophene synthesized from prepurified 2,4,5-trichlorophenol as the sole component.)

Residues resulting from the incineration or thermal treatment of 5011 contaminated with EPA Hazardous Waste Nos. F020, F021, F022, F023, F026, and $\mathrm{F} 027$.

\footnotetext{
* $(I, T)$ should be used to specify mixtures containing ignitable and toxic constituents.
} 
TABLE B-2

HAZARDOUS WASTES FROM SPECIFIC SOURCES

(40 CFR 261.32)

Industry and EPA

Hazardous Waste No.

Hazardous Waste

Hazard

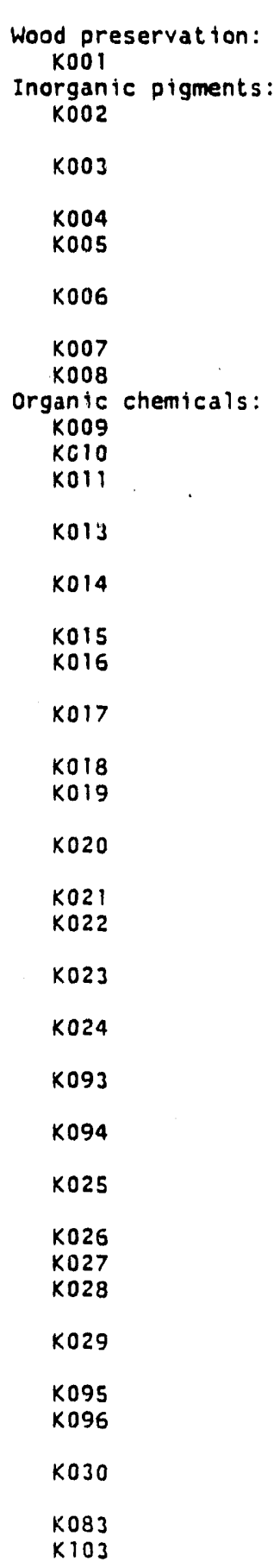

Bottom sediment siudge from the treatment of wastewaters from wood preserving processes that use creosote and/or pentachiorophenol

Wastewater treatment sludge from the production of chrome yellow and orange pigments

Wastewater treatment sludge from the production of molybdate orange pigments

Wastewater treatment sludge from the production of zinc yellow pigments Wastewater treatment sludge from the production of chrome green pigments

Wastewater treatment sludge from the production of chrome oxide green pigments (anhydrous and hydrated)

Wastewater treatment sludge from the production of iron biue pigments

oven residues from the production of chrome oxide green pigments

Distillation bottoms from the production of acetaldehyde from ethylene Distiliation side cuts from the production of acetaldehyde from ethylene Bottom stream from the wastewater stripper in the production of acryionitrile

Bottom stream from the acetonitrile column in the production of acryionitrile

Bottom stream from the acetonitrile purification column in the production of acrylonitrile

still bottoms from the distiliation of benzyl chloride

Heavy ends or distillation residues from the production of carbon tetrachloride

Heavy ends (sti11 bottoms) from che purification column in the production of eptchlorohydrin

Heavy ends from the fractionation column in ethyl chioride production

Heavy ends from the distillation of ethylene dichloride in ethylene dichloride production

Heavy ends from the distillation of vinyl chloride in vinyl chloride monomer production

Aqueous spent antimony catalyst waste from fluoromethanes production

oistillation bottom tars from the production of phenol/acetone from cumene

Distillation light ends from the production of phthalic anhydride from naphthalene

Distillation bottoms from the production of phthalic anhydride from naphthalene

oistillation itght ends from the production of phthalic anhydride from ortho-xylene

Dist 1 llation bottoms from the production of phthalic anhydride from ortho-xylene

0 istillation bottoms from the production of nitrobenzene by the nitration of benzene

Stripping still tails from the production of methy ethyl pyridines

Centrifuge and distillation residues from toluene di isocyanate production

Spent catalyst from the hydrochlorinator reactor in the production of $1,1,1$-trichloroethane

Waste from the product steam stripper in the production of $1,1,1$-trichloroethane

Distillation bottoms from the production of $1,1,1-t$-ichloroethane

Heavy ends from the heavy ends column from the production of 1,1,1-trichloroethane

Column bottoms or heavy ends from the combined production of trichloroethylene and perchloroethylene

Distillation bottoms from aniline production

process residues from aniline extraction from the production of aniline

(T) 


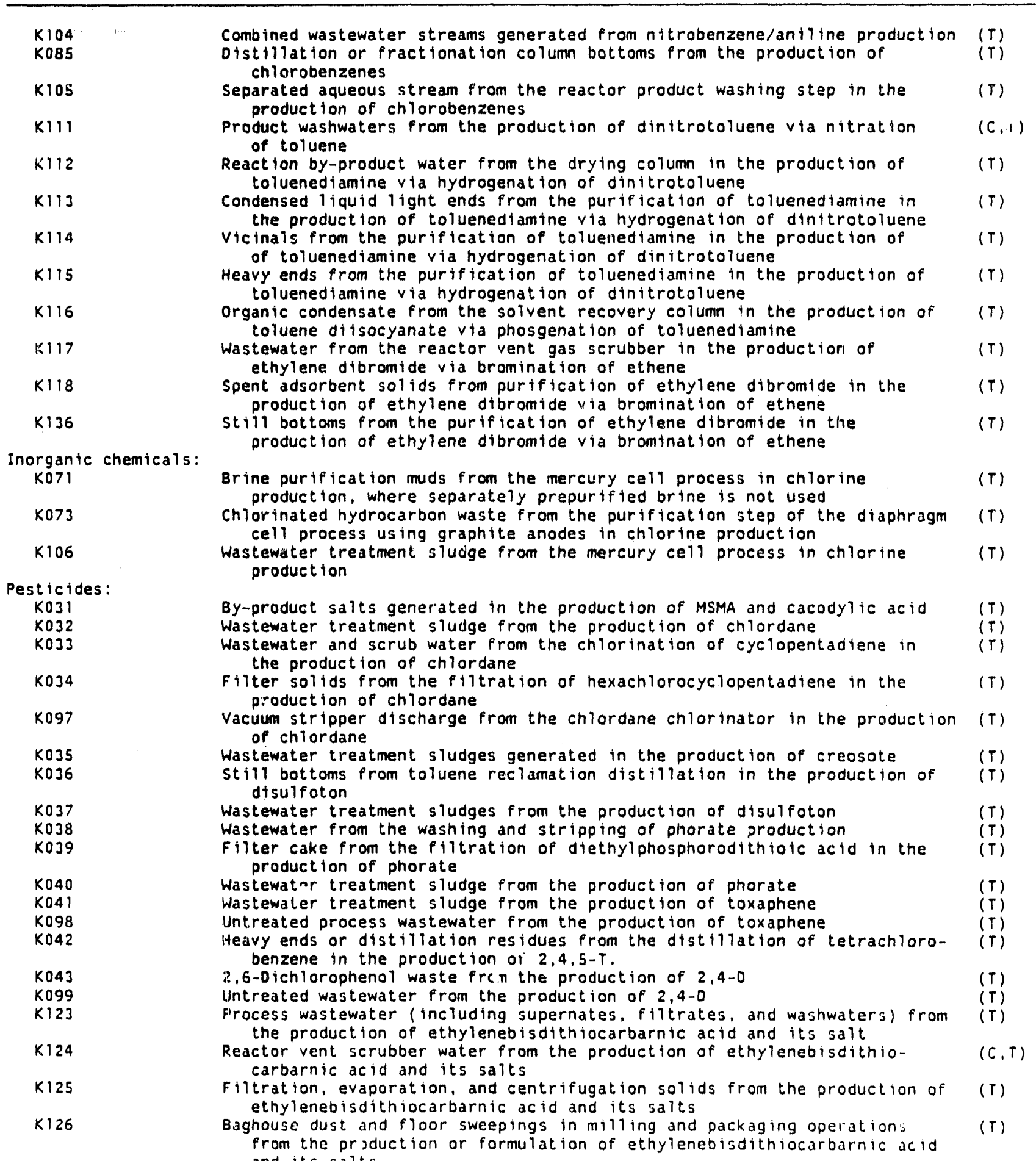




\begin{tabular}{|c|c|c|}
\hline $\begin{array}{l}\text { Industry and EPA } \\
\text { Hazardous Waste No. }\end{array}$ & Hazardous Wasle & $\begin{array}{l}\text { Hazaro } \\
\text { Code }\end{array}$ \\
\hline \\
\hline K044 & $\begin{array}{l}\text { Wastewater treatment sludges from the manufacturing and processing of } \\
\text { explosives }\end{array}$ & (R) \\
\hline K045 & Spent carbon from the treatment of wastewater containing explosives & (R) \\
\hline K046 & $\begin{array}{l}\text { Wastewater treatment sludges from the manufacturing, formulation, and } \\
\text { loading of lead-based initiat ing compounds }\end{array}$ & $(T)$ \\
\hline $\begin{array}{l}\text { K047 } \\
\text { Petro Refining: }\end{array}$ & Pink/red water from TNT operations & $(R)$ \\
\hline KO48 & Dissolved air flotation (DAF) float from the petroleum refining industry & $(T)$ \\
\hline K049 & slop ot emalsion solids from the petroleum refinting industry & ( $(\mathrm{T})$ \\
\hline K050 & Heat exchanger bundle cleaning sludge from the petroleum refining industry & ( \\
\hline $\begin{array}{l}\text { K051 } \\
\text { K052 }\end{array}$ & API separator sludge from the petroleum refining industry & $(\tau)$ \\
\hline \multicolumn{3}{|c|}{ Emicsion control duct / cludne from the primary oroduction of cteol in } \\
\hline K061 & $\begin{array}{l}\text { Emission control dust/sludge from the primary production of steel in } \\
\text { electric furnaces }\end{array}$ & $(\mathrm{T})$ \\
\hline K062 & $\begin{array}{l}\text { Spert pickle liquor generated by steel finishing operations of facilities } \\
\text { within the iron and steel industry (SIC Codes } 331 \text { arid } 332 \text { ) }\end{array}$ & $(C, T)$ \\
\hline \multicolumn{3}{|c|}{ 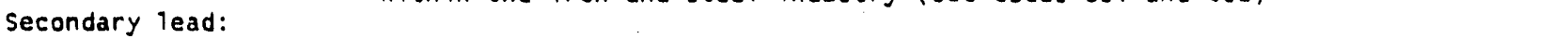 } \\
\hline K100 & $\begin{array}{l}\text { Waste leaching solution from acid leaching of emisston control dust/ } \\
\text { sludge from secondary lead smelting }\end{array}$ & (T) \\
\hline \multicolumn{3}{|l|}{$\begin{array}{l}\text { Veterinary } \\
\text { pharmaceuticals: }\end{array}$} \\
\hline K084 & $\begin{array}{l}\text { Wastewater treatment sludges generated during the production of veterinary } \\
\text { pharmaceuticals from arsenic or organo-arsenic compounds }\end{array}$ & $(T)$ \\
\hline K 101 & $\begin{array}{l}\text { Distillation tar residues from the distillation of aniline-based compounds } \\
\text { in the production of veterinary pharmaceuticals from arsenic or organo- } \\
\text { arsenic compounds }\end{array}$ & $(\mathrm{T})$ \\
\hline $\mathrm{K} 102$ & $\begin{array}{l}\text { Residue from the use of activated carbon for decolorization in the pro- } \\
\text { duction of veterinary pharmaceuticals from arsenic or organo-arsenic } \\
\text { compounds }\end{array}$ & $(T)$ \\
\hline \multirow{2}{*}{$\begin{array}{l}\text { Ink formulation: } \\
\text { K086 }\end{array}$} & & \\
\hline & $\begin{array}{l}\text { Solvent washes and sludges, caustic washes and sludges, or water washes } \\
\text { and sludges from cleaning tubs and equipment used in the formulation of } \\
\text { ink from pigments, driers, soaps, and stabilizers containing chromium } \\
\text { and lead }\end{array}$ & $(T)$ \\
\hline \multicolumn{3}{|c|}{ 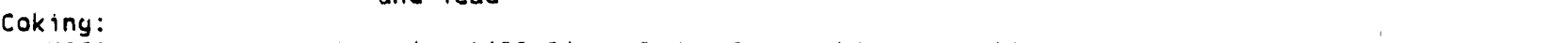 } \\
\hline K060 & Ammonia still 1 ime sludge from coking operations & ( $T$ ) \\
\hline K087 & Decanter tank tar sludge from coking operations & ( $(T)$ \\
\hline
\end{tabular}


TABLE B-3

ACUTE HAZAROOUS OISCARDEO COMMERCIAL PROOUCTS, OFF-SPECIFICATION SPECIES, CONTAINER RESIDUES, AND SPILL RESIDUES THEREOF(a)

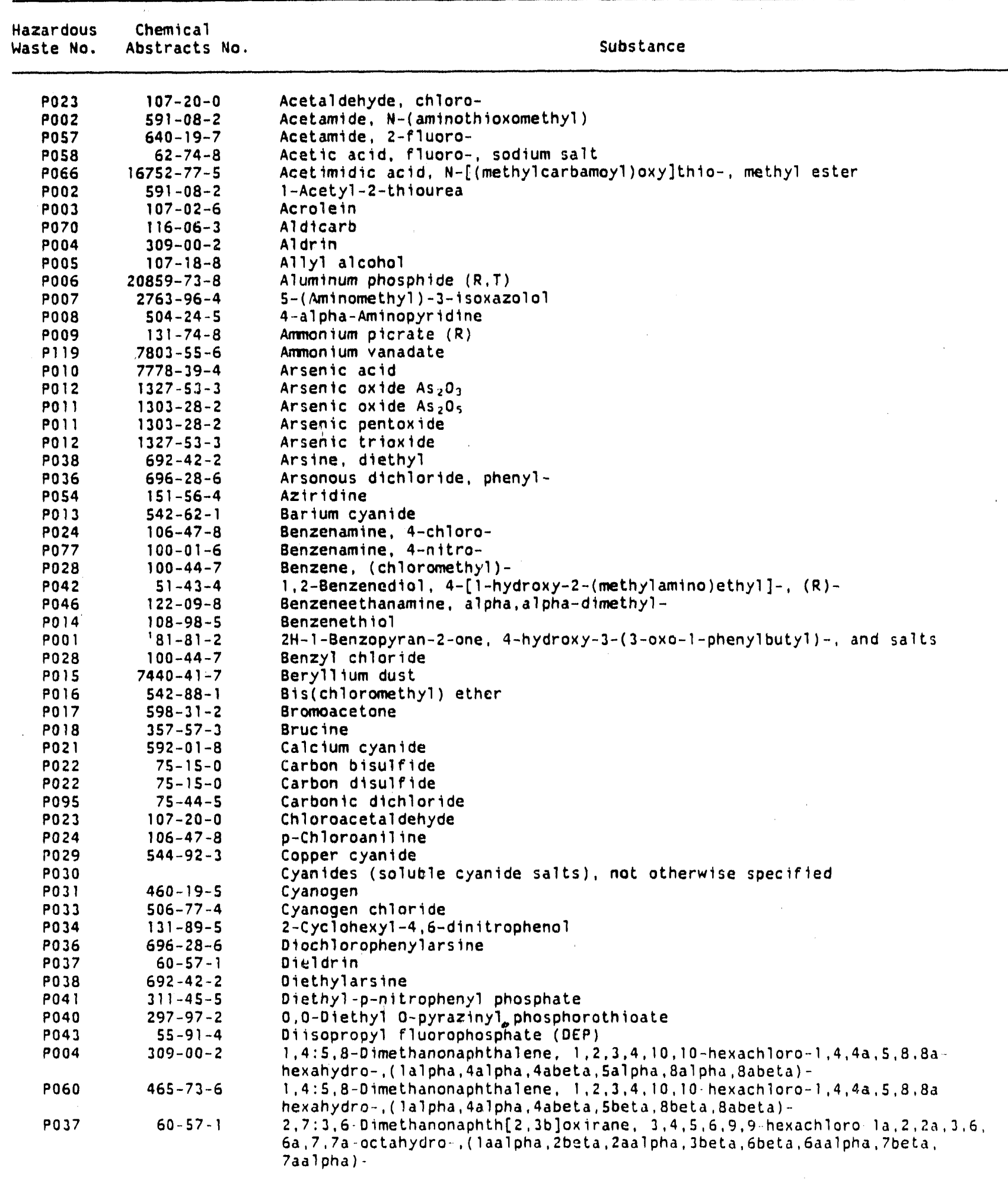




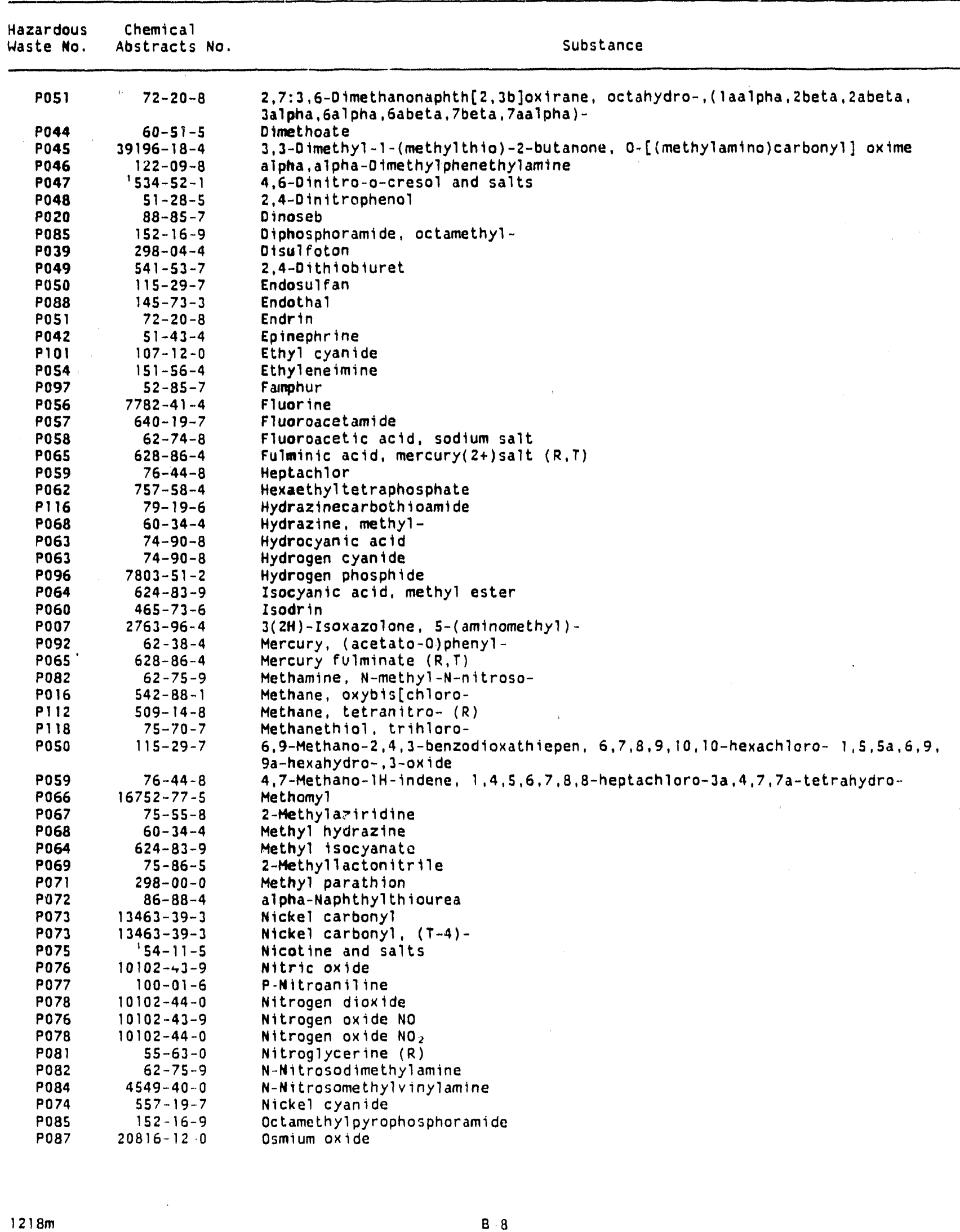




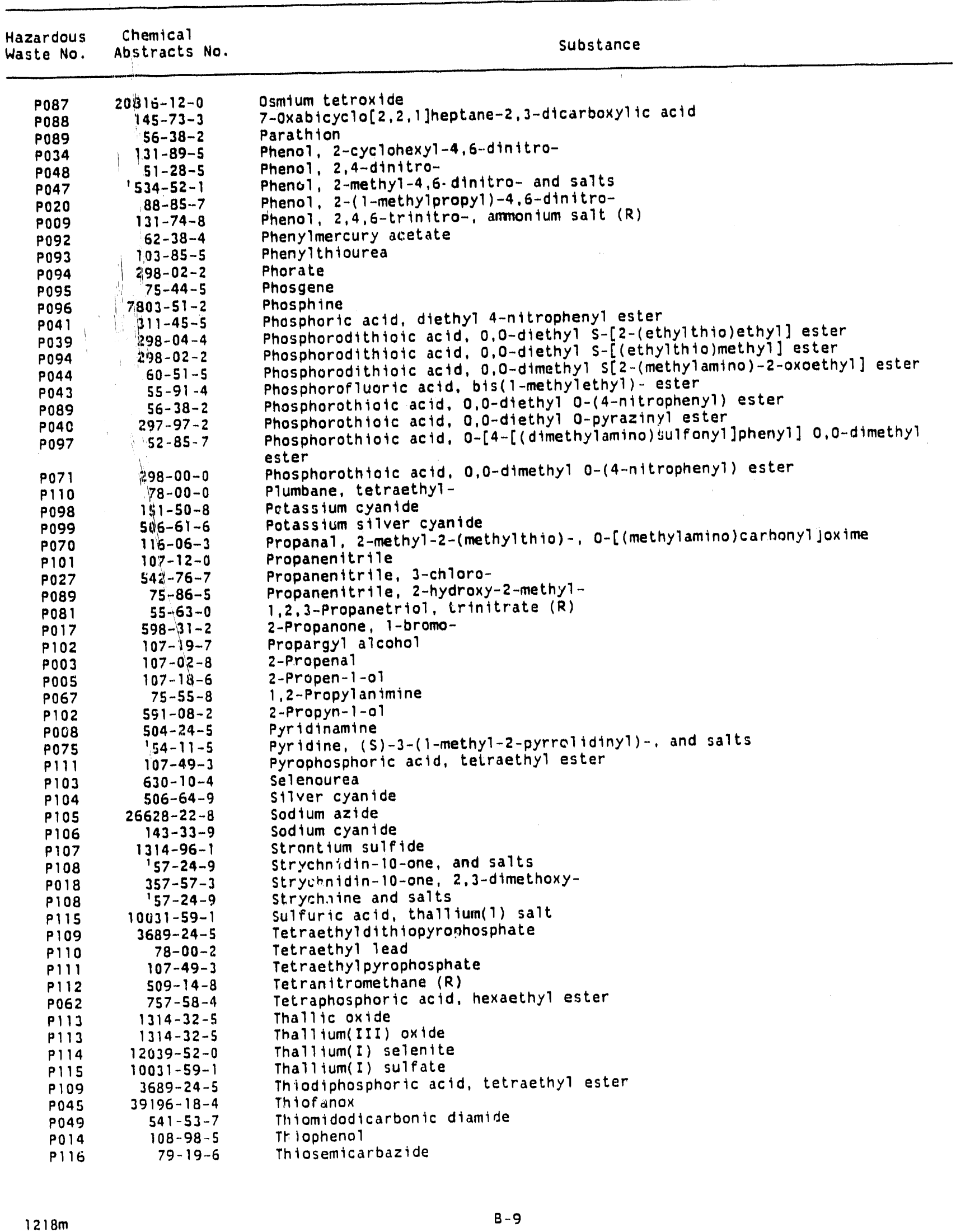




\begin{tabular}{|c|c|c|}
\hline $\begin{array}{l}\text { Hazardous } \\
\text { Waste No. }\end{array}$ & $\begin{array}{l}\text { Chemical } \\
\text { Abstracts No. }\end{array}$ & Substance \\
\hline $\begin{array}{l}\text { P026 } \\
\text { P072 } \\
P 093 \\
P 123 \\
P 118 \\
P 119 \\
P 120 \\
P 084 \\
P 001 \\
P 121 \\
P 122\end{array}$ & $\begin{array}{r}5344-82-1 \\
85-88-4 \\
103-85-5 \\
8001-35-2 \\
76-70-7 \\
7803-55-6 \\
1314-62-1 \\
4549-40-0 \\
81-81-2 \\
557-21-1 \\
\mid 314-64-7\end{array}$ & $\begin{array}{l}\text { Thiourea, (2-chloropheny } 1)- \\
\text { Thlourea, I-naphthalenyi- } \\
\text { Thtourea, phenyl- } \\
\text { Toxaphene } \\
\text { Trichioromethanethiol } \\
\text { Vanadtc acid, ammuntum salt } \\
\text { Vanadium(V) oxide } \\
\text { Vinylamine, N-methyl-N-nttroso- } \\
\text { Warfartn } \\
\text { Zinc cyanide } \\
\text { Zinc phosphide }(R, T)\end{array}$ \\
\hline
\end{tabular}

'CAS Number given for parent compound only

(a) Unless otherwise destgnated, these commercial chemical products, manufacturing chemical thtermediates, and of - specification commercial chemical products or manufacturing chemical intermediates are identifted as acute hazardous wastes $(H)$. 
TABLE $B-4$

TOXIC OISCARDED COMMERCIAL CHEMICAL PRODUCTS, OFF-SPECIFICATION SPECIES, CONTAINER RESIOUES, AND SPILL RESIDUES THEREOF'a)

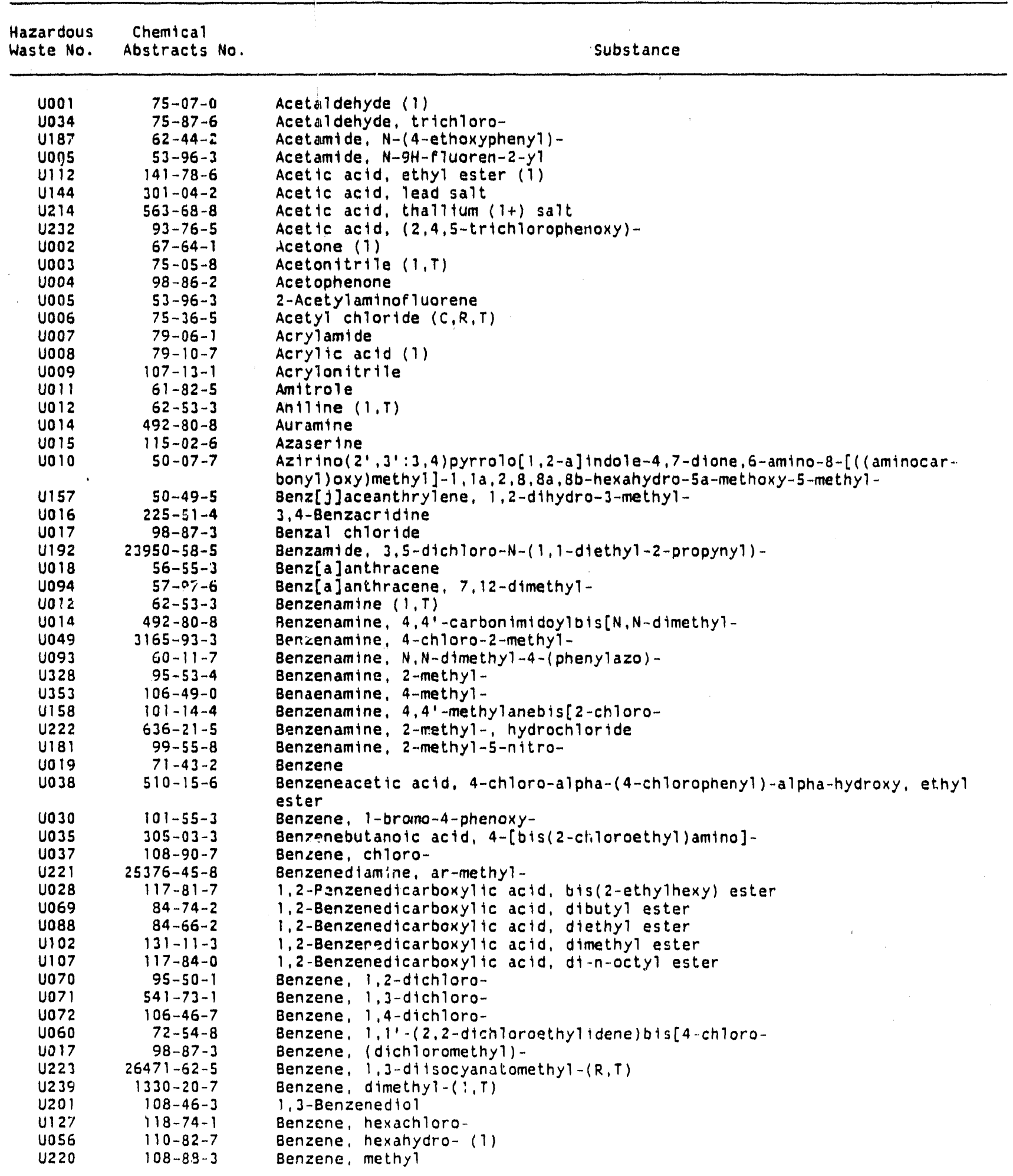




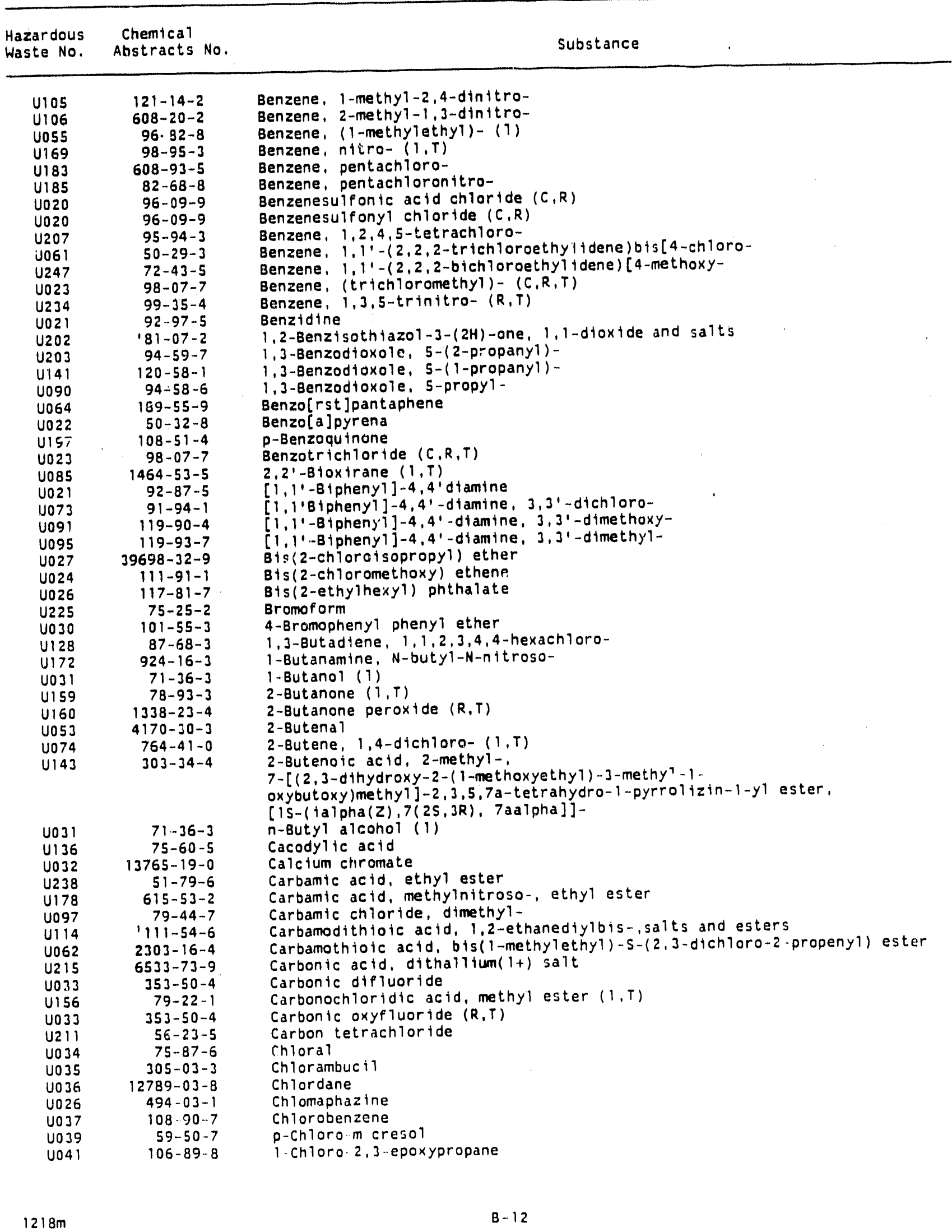




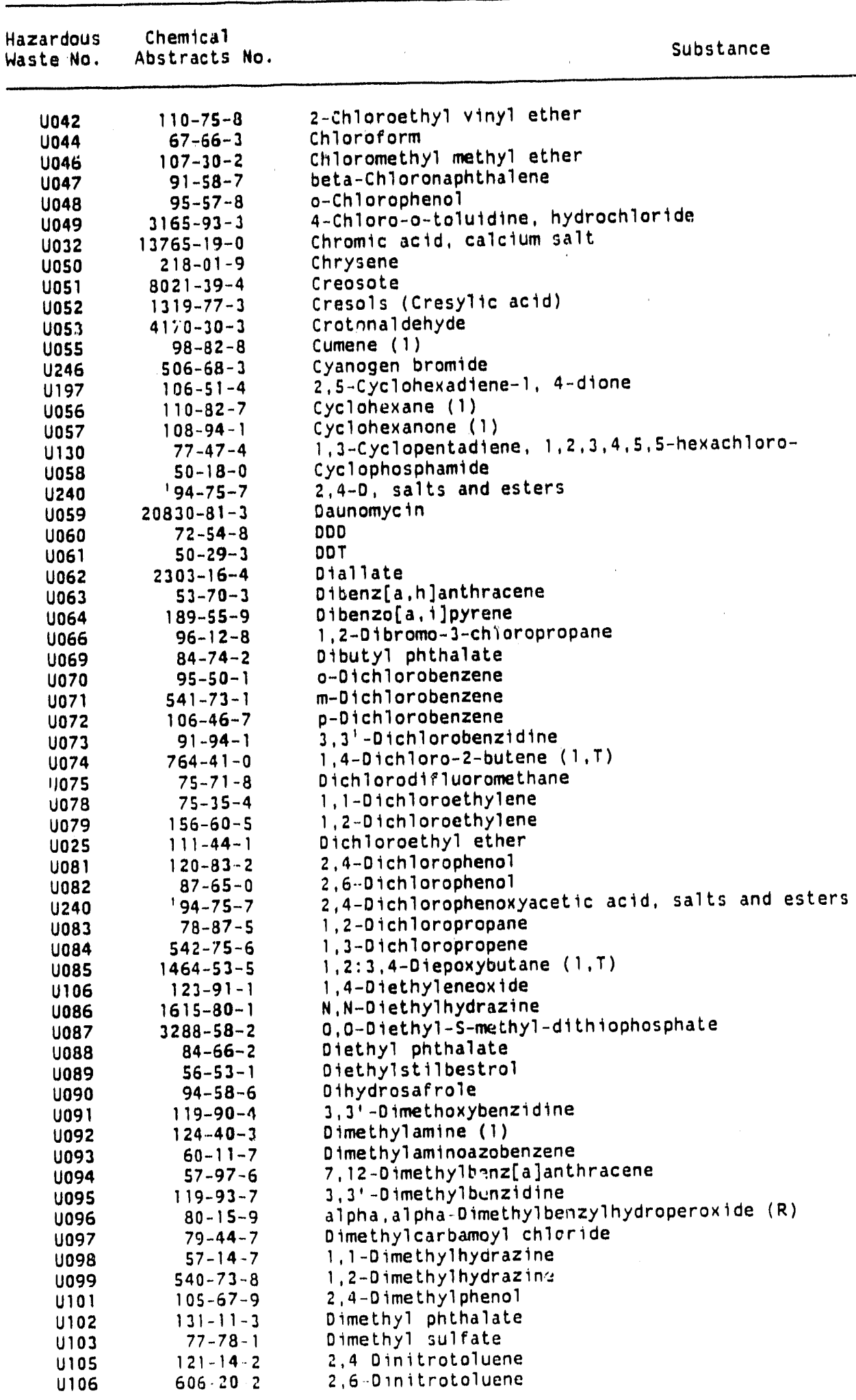




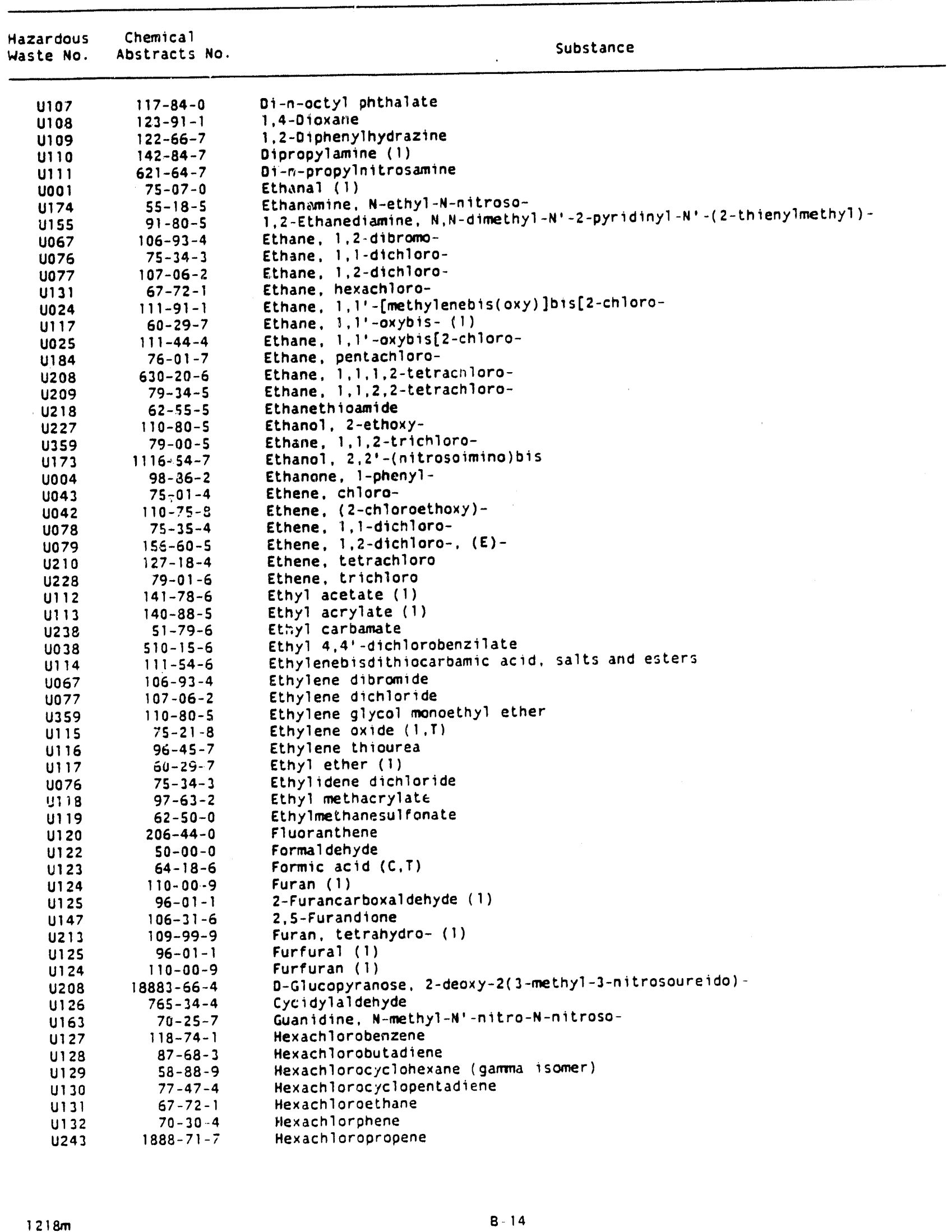




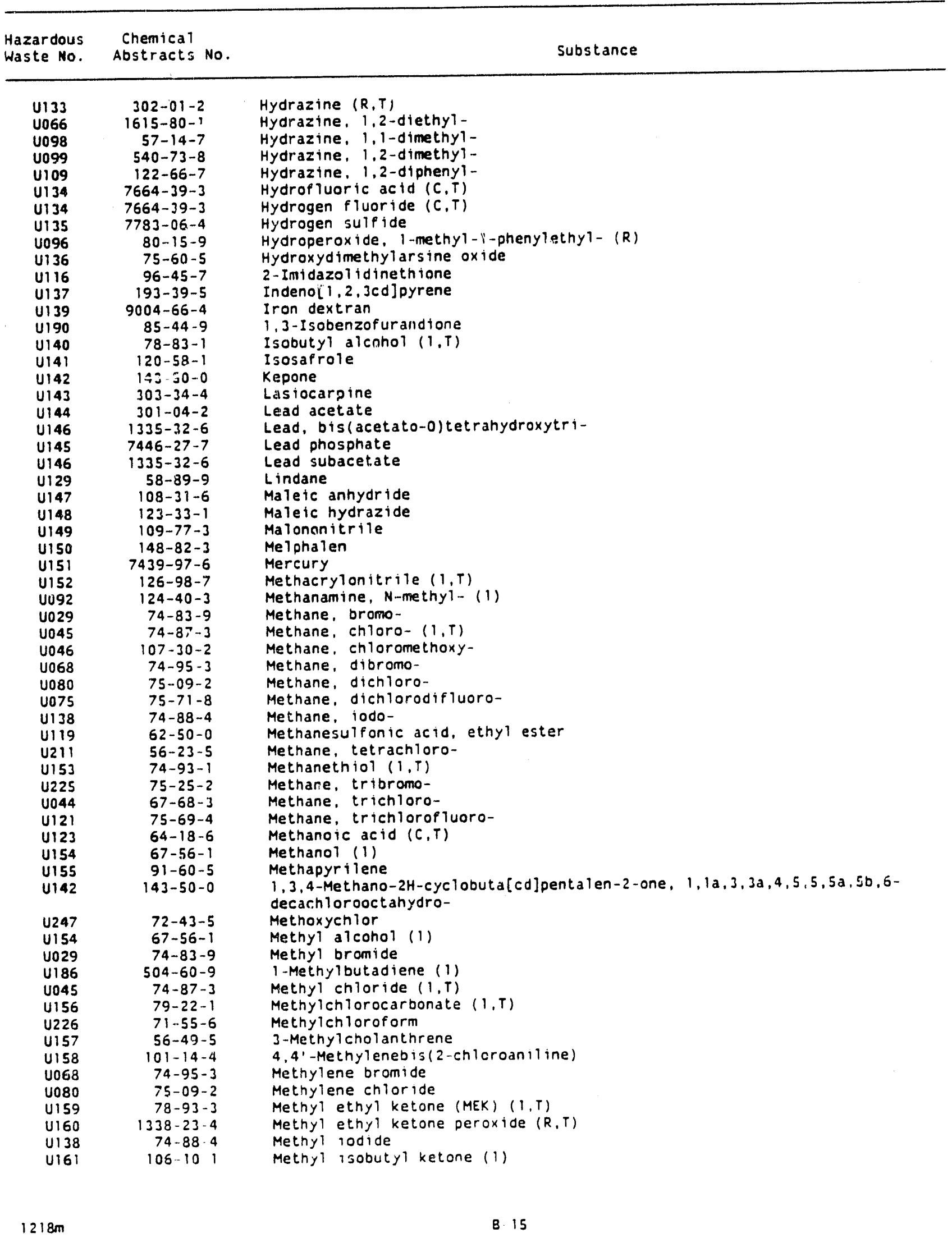




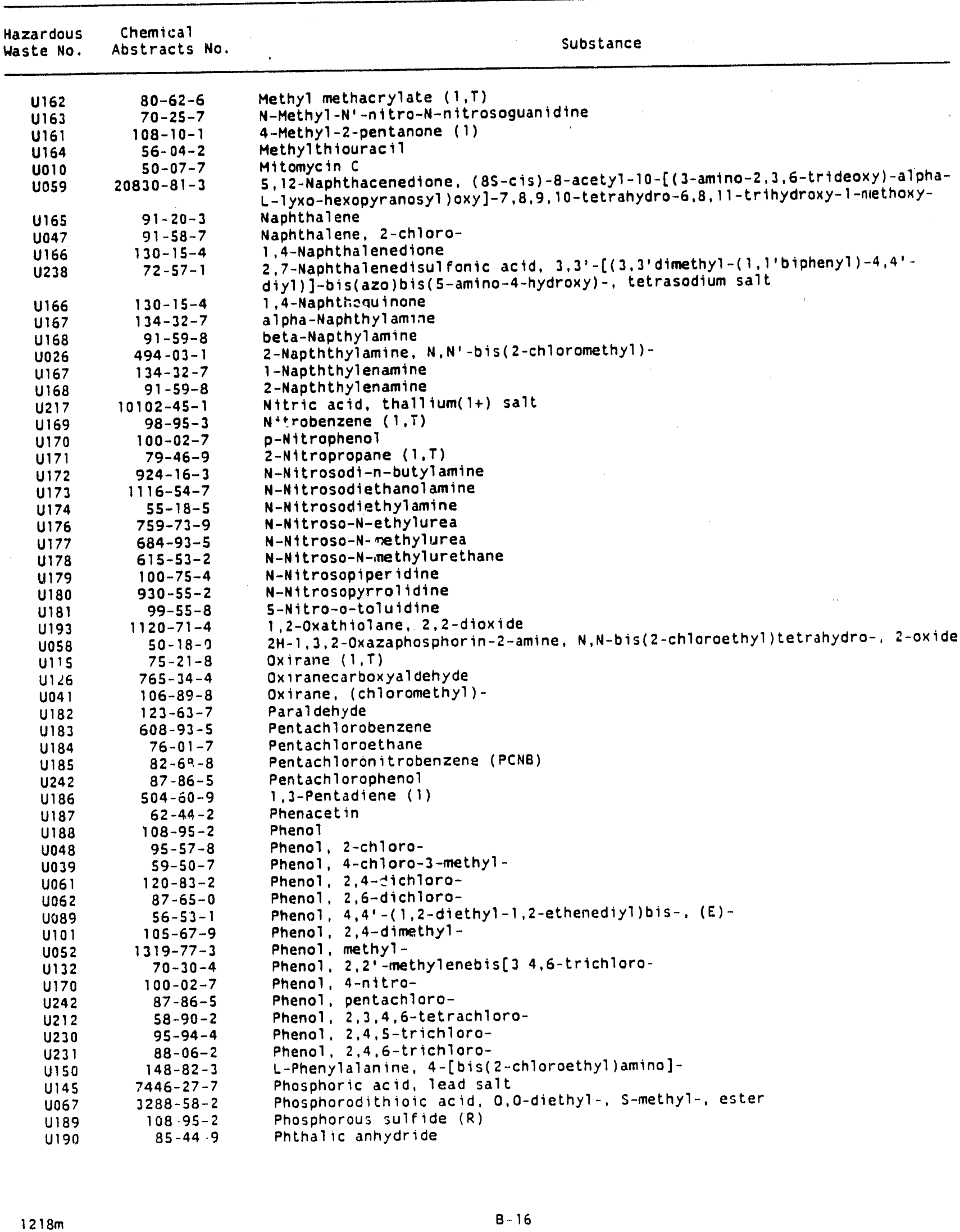




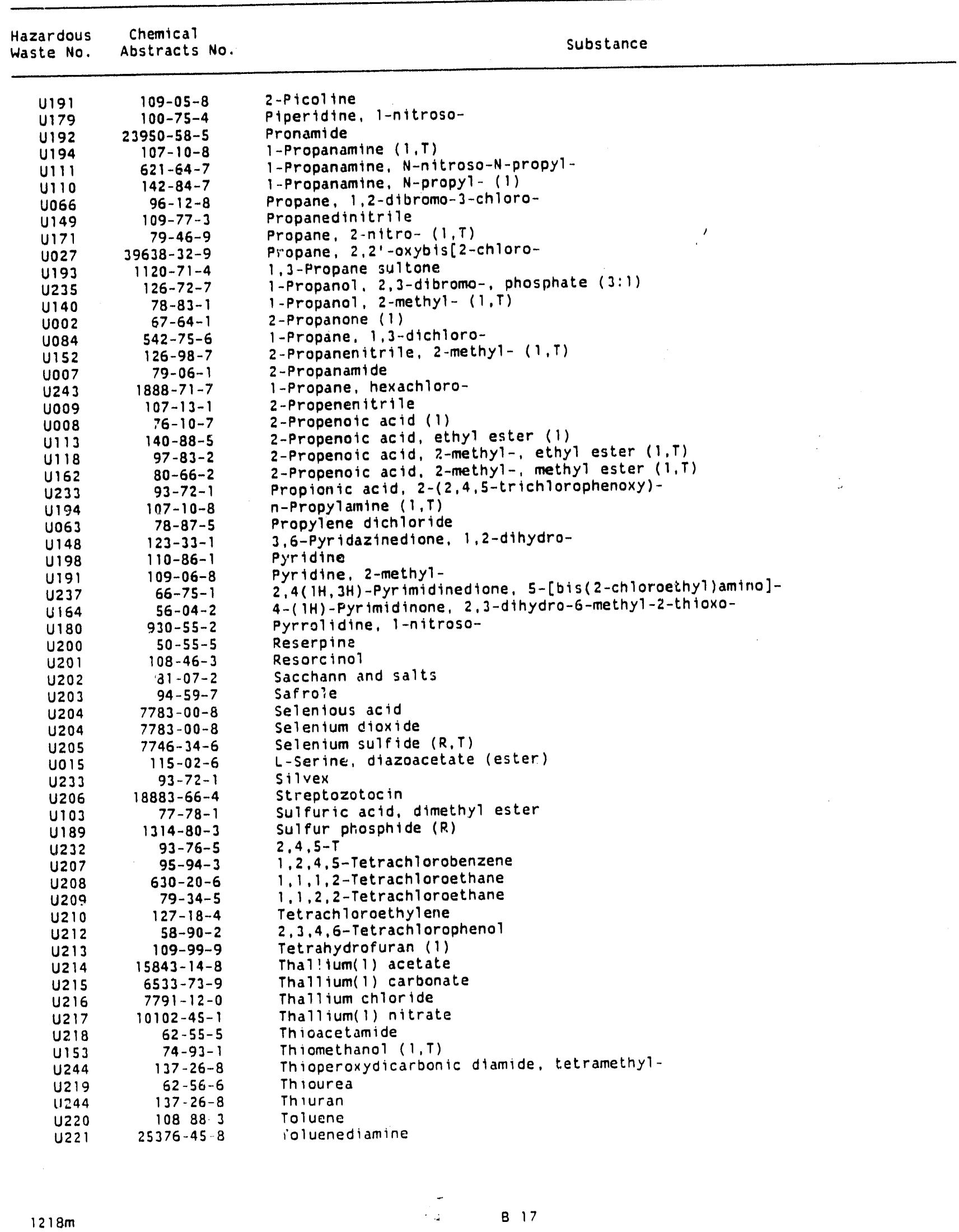




\begin{tabular}{|c|c|c|}
\hline $\begin{array}{l}\text { Hazardous } \\
\text { Waste No. }\end{array}$ & $\begin{array}{l}\text { Chemical } \\
\text { Abstracts No. }\end{array}$ & Substance \\
\hline $\begin{array}{l}U 223 \\
U 328 \\
U 353 \\
U 222 \\
U 011 \\
U 226 \\
U 227 \\
U 228 \\
U 121 \\
U 230 \\
U 231 \\
U 234 \\
U 182 \\
U 235 \\
U 236 \\
U 237 \\
U 176 \\
U 177 \\
U 043 \\
U 248 \\
U 239 \\
U 200\end{array}$ & $\begin{array}{r}26471-62-5 \\
95-53-4 \\
106-49-0 \\
636-21-5 \\
61-82-5 \\
71-55-6 \\
79-00-5 \\
79-01-6 \\
75-69-4 \\
95-95-4 \\
88-06-2 \\
99-35-4 \\
123-63-7 \\
26-72-7 \\
72-57-1 \\
66-75-1 \\
759-73-9 \\
684-93-5 \\
75-01-4 \\
81-81-2 \\
1330-20-7 \\
50-55-5\end{array}$ & 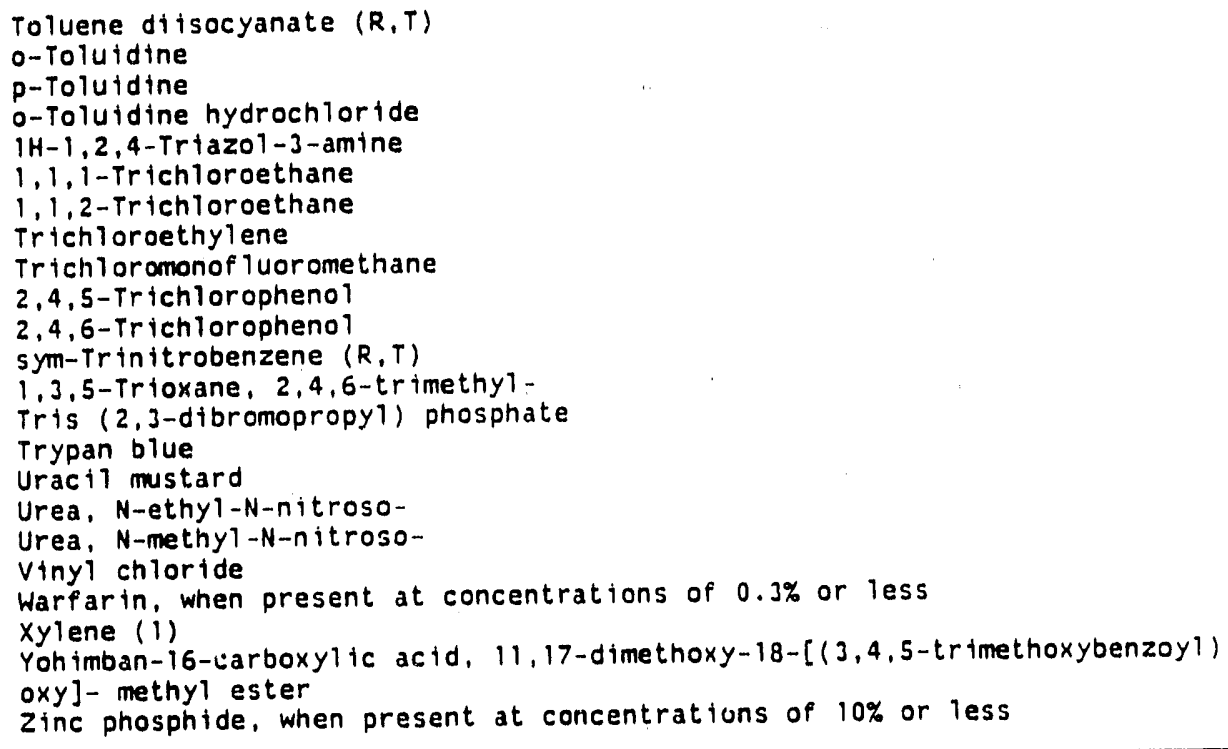 \\
\hline
\end{tabular}

'CAS Number given for parent compound only.

(a) Unless otherwise designated, these comercial chemical products, manufacturing chemical intermediates, and of $f$-specification commerical chemical products or manufacturing chemical intermediates are identified as acute hazardous wastes $(H)$. 


\section{ATTACHMENT C \\ HEALTH, SAFETY, AND ENVIRONMENTAL PROTECTION PROCEDURE EOR \\ EXCAVATING OPERATIONS}


HEALTH, SAFETY, AND ENVIRONMENTAL PROTECTION PROCEDURE

for

EXCAVATING OPERATIONS

prepared by

Environmental Compliance and Health Protection Division

Oak Ridge National Laboratory

Oak Ridge, Tennessee 37831 operated by

Martin Marietta Energy Systems, Inc.

for the

U.S. DEPARTMENT OF ENERGY

Under Contract NO. DE-ACO5-840R21400 


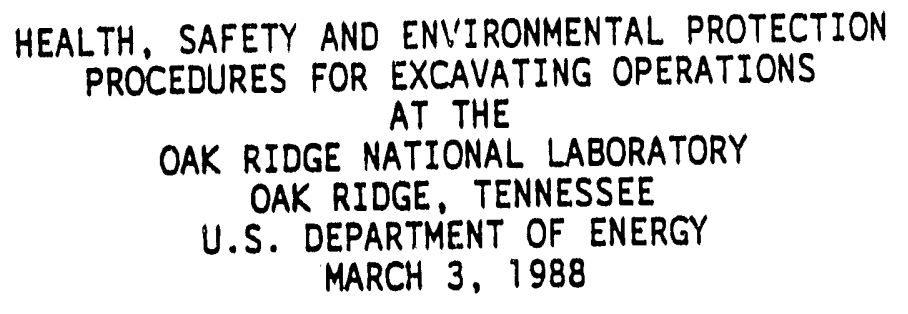

CONCUR:

DATE: $3 / 25 / 88$ CONCUR: $\frac{}{\text { D. C. Parzyck, Director }}$ DATE: $3 / 15 / 88$ Environmental Compliance and Health Protection Division CONCUR: $\quad \sum 4 k$ reaz JR.

E. H. Krieg, Jr., ORNL Site Manager Engineering Organization

CONCUR:

Gouelapka G. W. Oliphant. birector

Plant and Equipment Division

CONCUR: $\frac{\text { E. E. Reichle, Director }}{\text { Environmental Sciences Division }}$

conCUR: $\frac{\text { E. Reichle, Director }}{\text { Environmental Sciences Division }}$

DATE: 3.18 .88

DATE: $\quad 3 / 24 / 88$ CONCUR: $\frac{\text { J.H. Swanks Director }}{\text { Operations Division }}$

DATE: $3 / 24 / 88$ 


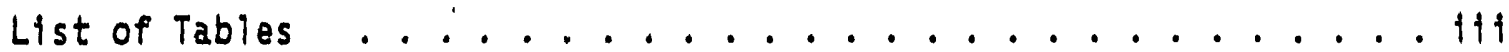

Acronyms ...................... . . iv

Abbreviations...................... v

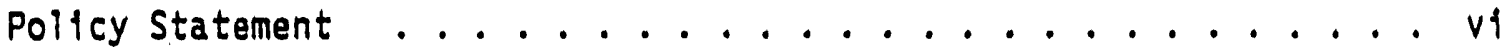

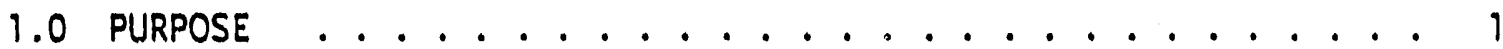

2.0 SCOPE . ........................ 1

3.0 LIMITATIONS AND SPECIAL CONDITIONS . . . . . . . . . . 1

3.1 Routine and Emergency Maintenance Activities . . . . . . . . 1

3.2 Subcontractors in Category 2 and 3 Areas . . . . . . . . . 2

3.3 Excavation Vartance ................. 2

3.4 Remedial Investigation/Feasibility Study (RI/FS) Project. . 2

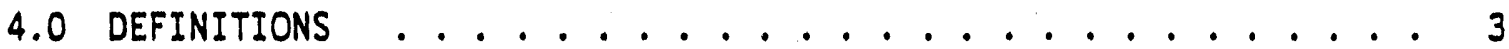

4.1 Action Description Memorandum (ADM) . . . . . . . . . 3

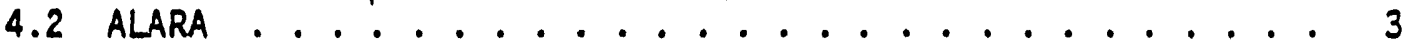

4.3 Category I Waste ................. . . 3

4.4 Category 2 Waste ............... . . 3

4.5 Category 3 Waste................... 3

4.6 Environmental Monitoring and Compliance Department, Industrial Hygiene Department, and Radiation Protection Department Personne?.............. 3

4.7 Field Representative................ 3

4.8 Project Manager . . . . . . . . . . . . . . . . 3

4.9 Excavation .................... 4

4.10 Hazardous Waste (Chemical) .............. 4

4.11 Mixed Waste . . . . . . . . . . . . . . . . . . 4

4.12 Project Quality Assurance Assessment (PQAA) . . . . . . . 4

4.13 Safety Assessment $(S A)$. . . . . . . . . . . . 4

4.14 Subcontractor ................ 7

5.0 RESPONSIBILITIES . . . . . . . . . . . . . . . . . . 7

5.1 Environmental Compliance and Health Protection Division. . 7

5.2 Health Diviston ................ g

5.3 Office of Operational Safety ............ . 9

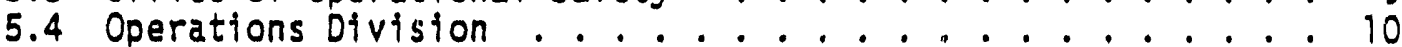

5.5 Engineering Division ............. 13

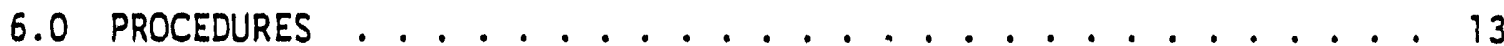

6.1 Excavation classffication Procedures . . . . 13

6.2 ALARA Guidelines ................ . . 14

6.3 Action Level Procedures ................ . 15

6.4 Radiation Work Permit Procedures . . . . . . . . 17

6.5 Waste llandling and Disposal Procedures . . . . . . . 17 
APPENDIX A CATEGORY 3 EXCAVATION TRAINING . . . . . . . . . . . . 19 APPENDIX B RADIOLOGICAL SOIL HANDLING CRITERIA, FLOWCHART,

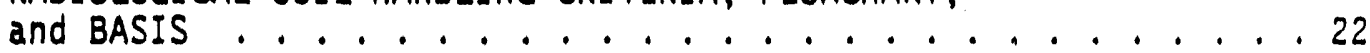

APPENDIX C RADIATION WORK PERMIT CRITERIA . . . . . . . . . . 26

APPENDIX D RADIOLOGICAL CONTAMINATION CRITERIA . . . . . . . . . . 28

REVISION/REVIEW STATUS . . . . . . . . . . . . . . . . 33 


\section{LIST OF TABLES}

Table

1 Excavation-classification categortes .......... 5

DI Recommended action level contamination gutide ........ 29

D2 Gulde for establishing contamination zones......... . 30

D3 Recommended maximum contamination guide for skin surface... 31

D4 Recommended maximum contamination guide for shoes

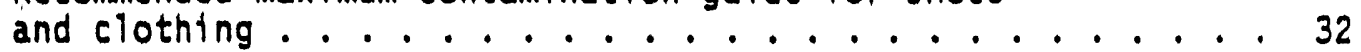




\section{ACRONYMS}

$\begin{array}{ll}\text { ADM } & \text { Action Description Memorandum } \\ \text { ALARA } & \text { As Low As Reasonably Achievable } \\ \text { BMP } & \text { Best Management Practices } \\ \text { CERCLA } & \text { Comprehensive Environmental Response, Compensation, and } \\ \text { Liability Act } \\ \text { CWA } & \text { Clean Water Act } \\ \text { EMCD } & \text { Environmental Monitoring and Compliance Department } \\ \text { ERDP } & \text { Environmental Review and Documentation Program } \\ \text { ES\&H } & \text { Environmental Safety and Heal th } \\ \text { HPIC } & \text { Health Physics Instrument Committee } \\ \text { IHD } & \text { Industrial Hygiene Department } \\ \text { ISD } & \text { Industrial Safety Department } \\ \text { MPC } & \text { Maximum Permissible Concelitration } \\ \text { ORNL } & \text { Oak Ridge National Laboratory } \\ \text { ORO } & \text { Oak Ridge Operations } \\ \text { OSHA } & \text { Occupational Safaty and Health Administration } \\ \text { NEPA } & \text { National Environmental Policy ACt } \\ \text { NPDES } & \text { National Pollutant Discharge Elimination System } \\ \text { P\&E } & \text { Plant and Equipment Division } \\ \text { POAA } & \text { Project Quality Assurance Assessment } \\ \text { PWMP } & \text { Project Waste Management Plan } \\ \text { RCRA } & \text { Resource Conservation Recovery Act } \\ \text { RI/FS } & \text { Remedial Investigation/Feasibility Study } \\ \text { RPD } & \text { Radiation Protection Department } \\ \text { SA } & \text { Safety Assessment } \\ \text { SARA } & \text { Superfund Amendments and Reauthcrization Act } \\ \text { SS } & \text { Safety Study } \\ \text { TLV } & \text { Threshold Limit Values } \\ & \end{array}$




\section{ABBREVIATIONS}

$B q / g$

$\mathrm{dpm} / 100 \mathrm{~cm}^{2}$

Energy Systems

hr

$\mathrm{mrad} / \mathrm{h}$
Becquerels per gram

Disintegrations per minute per one hundred square centimeters

Martin Marfetta Energy Systems, Inc.

Hours

Mllilrad per hour 
POLICY STATEMENT

It is the policy of the Oak Ridge National Laboratory (ORNL). Martin Marietta Energy Systems Inc. (Energy systems), and the U.S. Department of Energy (DOE) to ensure that excavation operations are carried out in full compliance with all applicable health, safety, and environmental rules and regulations, and without undue risk to worker health and safety or to the environment. To implement this policy, a health, safety, and environmental controls program will be maintained that will be applicable to all excavation operations, those performed by Laboratory personnel as well as work performed by others for or at the Laboratory under contractual arrangements. 


\section{ENVIRONMENTAL SAFETY AND HEALTH PROTECTION PROCEDURES FOR EXCAVATING OPERATIONS}

\subsection{PURPOSE}

This document is issued as an environmental, safety and health implementation procedure to assure the safety and health of personnel and protection of the environment during excavation activities.

\subsection{SCOPE}

This procedure estabilishes the procedures and responsibilities for ensuring that planning and implementation of all excavation activities include ALARA (As Low As Reasonably Achievable) objectives and that all operations meet the criteria of ALARA. ALARA objectives include:

- ensuring that personnel exposure to radiation, radioactive contamination, chemical agents, or other potentially harmful substances is kept ALARA;

- controlling the release to the environment of radioactive, chemical, or other deleterious materials to a level that is ALARA;

- conducting all operations in full compliance with Procedures and Practices for Radiation Protection (ORNL Health Physics Manual), Procedures and Practices for Protection Against Chemical and Physical Stresses (ORNL Industrial Hygiene Manual), procedures given in the ORNL Environmental Protection Manual, and the ORNL Safety Manual, as well as standards and regulations of the Occupational Safety and Health Administration (OSHA) and the Environmental Protection Agency (EPA).

\subsection{Limitations and Special Conditions}

3.1 Routine and Emergency Maintenance Activities - Routine maintenance activities involving minor excavations (e.g., installing power poles, planting shrubs, etc.) and emergency utility repairs are, in most cases, exempted from the special documentation requirements of this procedure (Action Description Memoranda [ADM], Safety Assessments [SA], Project Quality Assurance Assessments [PQAA] and Project Waste Management Plans [PWMP]). This exemption does not eliminate the requirement for an excavation/penetration permit and site classification review by the Industrial Hygiene Department (IHD) and Radiation Protection Department (RPD) as stated in Section 5.4.7. These site classification reviews may, on a case-by-case basis, result in reconsideration of special documentation requirements. 
3.2 Subcontractors in Category 2 and 3 Areas - It is Martin Marietta Energy Systems' intent to assure the development of capable and available subcontractors to provide Category 2 and 3 excavation support. These qualified subcontractors will be used for excavation activities in these areas whenever possible. Exceptions to the use of qualified subcontractors will be in those emergency or unusual situations where: schedule requirements prohibit use of the required bid, evaluation, award, and mobilization process necessary for subcontracting; hazard potential is high but hazard definition is insufficient for competitive fixed-price contracting; special expertise is not available in the private sector; or there are no responsive bidders. In these cases, or others which can be properly justified, Rust Engineering or operating contractor personnel would be used. Work plans calling for use of excavation subcontractors in these areas must receive approval from the Environmental Compliance and Health Protection Division Director and the Manager of the Office of Operational Safety.

3.3 Excavation Variance - A process through which special documentation requirements of this procedure may be waived for excavation activities, e.g. minor excavations/penetrations associated with a research project. In no case does this variance eliminate the requirement for an excavation/penetration permit and site classification review by the IHD, Environmentai Monitoring and Compliance Department (EMCD) and RPD as stated in Section 5.4.7. The variance request in the form of a letter shall be directed to the Environmental Compliance and Health Protection Division Director and contain, as a minimum, the following information:

1. Copy of the Excavation Penetration Permit with engineering approval( $s$ ),

2. Exact location of the intended excavation,

3. Type of excavation, i.e., how it is to be accomplished and probable depth,

4. Estimate of waste/material to be generated,

5. Who will perforin the excavation, i.e., ORNL Plant and Equipment (P\&E), Subcontractor, etc. AND the proposed schedule for work.

6 . Why the variance is being requested.

3.4 Remedial Investigation/Feasibility Study (RI/FS) Project - The RI/FS Subcontractor responsibie for this project is contractually required to comply with ORNL policies and procedures. While the subcontractor shall comply with the limits provided in this procedure there will be variations in the methods by which the compliance is accomplished. The Subcontractor activities are controlled by an Environmental Safety and Health (ES\&H) Plan and referenced detail operating procedures prepared by the Subcontractor and reviewed and approved by ORNL. 


\subsection{DEFINITIONS}

4.1 Action Descriotion Memorandum (ADM) - A written report documenting the environmental review of planned construction projects. The ADM is a formal agreement document: it is part of the Best Management Practices (BMP) Plan of ORNL's National Pollutant Discharge Elimination System (NPDES) permit; it is incorporated into the permanent environmental record at ORNL; it is retained in DOE/Oak Ridge Opriations (ORO) files; and it is transmitted to DOE Headquarters in partial fulfillment of DOE's National

Environmental Policy Act (NEPA) compliance obligations. It gives the measures that will be taken during project construction and project operations to ensure the protection of the environment. ADMs are prepared by Environmental Review and Documentation Program (ERDP) personnel.

4.2 ALARA - ALARA is an acronym for "as low as reasonably achievable." It is a philosophy that has been effectively applied in the nuclear industry woridwide. Its objective is to reduce the potentially harmful effects of radiation and other hazardous and environmentally deleterious materials to the lowest levels commensurate with sound economics and sound operating practice.

4.3 "Category 1 - Soil generated from excavation operations where alpha activity is near the lower limit of field instrument detection capabilities (less than $300 \mathrm{dpm} / 100 \mathrm{~cm}^{2}$ ), and/or beta/gamma emitters produce dose rates below $0.02 \mathrm{mrad} / \mathrm{h}$.

4.4 "Category 2 - Waste (soil) generated from excavation operations where alpha activity is equal to or greater than 300 andior less than $6000 \mathrm{dpm} / 100 \mathrm{~cm}^{2}$ and beta-gamma readings are equal to or greater than 0.022 and less than $5.0 \mathrm{mrad} / \mathrm{h}$.

4.5 Categery 3 - Waste (soil) generated from excavation operations where alpha activity is equal to or greater than $6000 \mathrm{dpm} / 100 \mathrm{~cm}^{2}$ and/or beta/gamma is equal to or greater than $5.0 \mathrm{mrad} / \mathrm{h}$.

4.6 Environmental Monitoring and Comoliance Department. (EMCD). Industrial Hyaiene Department (IHD), and Radiation Protection Department (RPD) Personnel - Reference is made to ORNL representatives from these respective departments throughout these procedures. These representatives can be subcontractor personnel where authority is established through contractual and subcontractual ES\&H Plans properly approved by the Environmental Compliance and Health Protection Division and the Office of Operational Safety.

4.7 Excavation - The generating and handling of soil or fill material encountered when passing through a surface such as a basement or floor slab, earth surface, or roadway by means of drilling, cutting, boring, digging, etc. Each excavation will require completion of a Construction Excavation/Penetration Permit

- Contains no free liquids. 
(UCN-12096) or an ORNL P\&E Division Excavation/Penetration Permit (UCN-14112). Each permit shall be reviewed and classified by IHD and RPD according to Table 1. Copies of each completed permit shall be provided to the IHD, RPD and to the EMCD prior to initiating excavation activities.

4.8 Project Manacier - An Energy Systems employee (designated by Construction Engineering for capital projects, and for other projects designated by the responsible division, e.g. operations engineer, principal investigator, supervisor, etc.), assigned the responsibility for accomplishing a specifically designated work effort. The project manager is responsible for implementation and control of the project work within contract specifications, and ORNL, Energy Systems, and DOE policies, procedures, and regulations.

4.9 Field Representative - Employees of the ORNL ES\&H disciplines (EMCD, IHD, Industrial Safety Department [ISD] and RPD) and other support groups (Quality Assurance, Laboratory Protection, Fire Protection, etc.) assigned project-specific oversight responsibilities. Oversight responsibility includes those on-site observation, inspection, assessment, and audit actions necessary to assure work implementation is being performed in accordance with ORNL, Energy Systems, and DOE policies, procedures, and regulations. The respresentatives are also responsible for providing ES\&H guidance and directions where appropriate and for initiating stop-work actions where the work effort is not in compliance with policies, procedures, and regulations and poses either eminent danger to personnel or potential insult to the environment.

4.10 Hazardous Waste (Chemical) - Substances identified as hazardous under Resource Conservation and Recovery ACt (RCRA). Comprehensive Environmental Response, Compensation, and Liability ACt (CERCLA), Superfund Amendments and Reauthorization Act (SARA), or by OSHA, or substances environmentally controlled under the NPDES provisions of the Clean Water Act (CWA). These include but are not restricted to grease, fuel oil, gasoline, hydraulic oil. cooling fluid, etc.

4.11 Mixed Waste - Any hazardous waste identified in Section 4.9 above which also contains low levels of radioactivity beyond the levels noted in Section 4.3 .

4.12 Project Quality Assurance Assessment (POAA) - A documented evaluation of a project in which potential fallures and uncertainties are identified and the associated risk is determined.

4.13 Safety Assessment (SA) - A brief, factual, and objective doclment which determines if activities involve hazards, including potential for release and/or exposure to radioactive and toxic materials that require elimination, control, or mitigation. An affirmative finding in the SA establishes the need for additional 
Table 1. Excavation-classification categorles

Class Probability* Protective Measures

Category 1 Low

Category $2 \quad$ Moderate

Protective clothing will be needed only if radioactive or chemical contamination is encountered.

Generated waste cuttings will be disposed as nonradioactive and nonhazardous waste if nelther radioactivity nor chemical hazard (including oils and oily wastes) are encountered during operations.

Health, Safety, and Environmental personnel will monitor operations at least twice during excavation activities and again at completion of construction.

Employee basic training will be required as defined in 5.1.15.

Protective clothing will be needed if radioactive or chemical contamination is encountered.

Measures will be taken to contain generated waste (e.g., use of plastic ground covers, use of pans to contain cuttings, tanks and/or lined pits to contain fluids especially for drilling operations).

Surveillance by RPD will be continuous with periodic surveillance required by IHD and EMCD personiel for control of the anticipated materials to be encountered throughout excavating activities.

Proper disposal containers for radioactively and/or chemically contaminated and/or oily waste will be avallable on site at all times.

Waste Handing and Disposal Procedures in Section 6.5 will be followed in disposing of generated waste.

Employee basic training will be required as defined in Section 5.1.15. 
Table 1 - Excavation-classification categories (Continued)

\begin{tabular}{|c|c|c|}
\hline Class & Probability & Protective Measures \\
\hline Category 3 & High & $\begin{array}{l}\text { Protective clothing will be required. } \\
\text { Measures will be taken to contain generated waste } \\
\text { (e.g. use of plastic ground covers, use of pans to } \\
\text { contain cuttings, tanks and/or linec pits to } \\
\text { contain fluids especially for drilling operations). } \\
\text { Continuous surveillance by RPD, IHD and EMCD } \\
\text { personnel will be performed at all excavating } \\
\text { activities. } \\
\text { Advanced training as defined in Appendix A will be } \\
\text { required by all excavation personnel and others as } \\
\text { directed by the Environmental Compliance and Heaith } \\
\text { Protection Division. } \\
\text { Proper disposal containers will be required. } \\
\text { Radiation Work Permits will be required when } \\
\text { conditions warrant (see Appendix C and the ORNL } \\
\text { Health Physics Procedure Manual Procedure } 3.6 \text { ). } \\
\text { Adherence to Action Levels in Section } 6.5 .5 \text { will be } \\
\text { required in disposing of generated waste. }\end{array}$ \\
\hline
\end{tabular}

* Probability of encountering radioactive and/or chemical contamination during excavation. 
safety documentation. DOE Order 5481.18 calls for preparation of safety assessments for all new projects and for modifications to existing facilities to identify risks that are assoclated with project or facility construction or operations.

4.14 Subcontractor - For the purpose of this excavating operations procedure includes ORNL P\&E Division, Rust Engineering, Subcontractors, and fixed-price prime contractors.

\subsection{RESPONSIBILITIES}

\subsection{Environmental Compliance and Heal th Protection Division}

5.1.1 Heips set ALARA goals, provides radiological safety, health and environmental protection guidelines, and coordinates the radiation protection, health and environmental protection portion of excavation operations.

5.1.2 Reviews all requests for proposal documents requiring excavation activities, provides data on radiological and hazardous chemical aspects of the proposed excavation site(s) and provides input into the selection of outside contractors.

5.1.3 Ensures the preparation of an ERDP Document, (e.g. an $A D M)$, for each well-drilling or other excavation project to document potential environmental consequences of the project and to provide the measures that will be taken to prevent environmental impact; also, ensures proper participation in and endorsement of the $A D M$ by responsible management and staff personnel from all participating divisions and programs.

5.1.4 Reviews and assigns classification ratings of all Excavation/Penetration Permits in a timely manner. Provides immediate turnaround of review and classification assignment in emergency situations.

5.1.5 Coordinates and provides EMCD, IHD, and RPD personnel for surveillance of excavation operations or provides personnel from the departments for oversight where subcontractors are assigned surveillance responsibility through contractual authority.

5.1.6 Provides consultation on the disposition of all radiologically or chemically contaminated materials generated at excavation sites as required by waste generators or waste operations.

5.1.7 Coordinates, in consultation with Operations Division or other divisions carrying out excavation operations, the issuance of dosimeter badges for external radiation 
monttoring of ORNL and Subcontractor personnel; handles the processing of all personnel dosimeter badges and maintains records.

5.1.8 Advises Operations Division or other divisions and provides subcontractor bid document requitements for protective clothing and equipment, containment of radiologically and/or chemically contaminated material. contamination control, and handing of contaminated tools and equipment.

5.1.9 Recommends and approves in concert with the Health Physics Instrument Committee (HPIC) and callbrates all field instruments used for radiological survefllance.

5.1.10 Provides whole body counting and bloassay services, as deemed necessary, for personnel.

5.1.11 Coordinates the industrial hygiene aspects of activities by assessment of all excavation operations and provides guidelines for controlling the potential chemical and physical stresses that may affect the health and well-being of personnel.

5.1.12 Provides on-site industrial hygiene survelllance of excavation operations, when requested, or if significant personnel hazards (such as toxic materials, dusts, or gases) are anticipated.

5.1.13 Provides respirator training of perscinnel and fit testing of respirators upon receipt of a physician's written statement certifying the individual is medically fit to be a respirator wearer. Retesting/retraining will occur at 18-month intervais.

5.1.14 Determines need and provides instruments and IHD representatives for monitoring work sites for chemical and physical stressors prior to and during excavation operations.

5.1.15 Provides basic training for all crews excavating in Category 1 and 2 areas. Training is to include: fundamentals of radiation protection and control: spill prevention, and cleanup; emergency procedures; zoning regulations; and other health. safety, and environmental protection procedures.

5.1.16 Provides specific advanced training for all crews excavating in Category 3 areas. Training is to include: biological effects of radiation; personnel monitoring techniques: correct procedures for donning and safely removing protective clothing; review of proper use of 
respiratory protection equipment: contamination control management and technlques (including decontamination); and waste disposal. Detalled information on the Category 3 training requitrements can be found in Appendix $A$.

5.1.17 Oversees cleanup of spll1s and appropriate handling of the resulting waste materials.

5.1.18 Provides field representative oversight of excavating operations at a level necessary to assure work implementation is being performed in accordance with ORNL, Energy Systems and DOE policles, procedures, and regulations.

5.1.19 Review and update this procedure on a frequency NOT to exceed every 2 years with a new revision number assigned to each review. All reviews and updates will be noted in the review status found on the last page of this document.

\subsection{Health Division}

5.2.1 Provides medical evaluation of ORNL employees' fitness to be a respirator wearer. For Subcontractor and fixed-price primo contract personnel, certification of medical fitness will be obtained from a private physician. Recertification will occur at 18-month intervals.

5.2.2 Provides emergency medical care for employees and subcontractors involved in excavation activities as the need arises.

\section{3 effice of Operational Safety}

5.3.1 Coordinates industrial safety oversight of training programs and survelliance of excavation operations by assessment of excavation operations, and provides guidelines for controlling potential physical hazards that may affect the well-being of personnel. including related OSHA requirements.

5.3.2 Advises excavating personnel on requirements for hard hats, safety glasses, and other safety-related personal protective equipment.

5.3.3 Examines excavation equipment prior to operation to ensure proper electrical grounding in accordance with the Excavation/Penetration Permit.

5.3.4 Reviews and approves SAs or Såfety Studles (SSs) for excavation work.

5.3.5 Appraises program (or coordinates appralsal by a Directors Review Committee and other ES\&H personnel) and provides report to ORNL Management. 


\subsection{Operations Division Cor Other Division Responstble for Excavatting} Deerations

5.4.1 Is responstble for overseeing all excavating operations. This is accomplished through a project manager who is assigned the responsibility for assuring that each job or subcontract is performed in full compllance with this and other applicable ORNL pollcies/procedures and for assuring proper interface between subcontractors and on-site support organizations. The project manager wtll, as a minimum, be on site at all times during activity in Category 3 areas or at any time contamination or other hazardous materlals are encountered.

5.4.2 Ensures that all applicable procedures are followed; this includes ensuring that operations are conducted in compllance with ORNL ALARA policy and guldelines, OSHA and EPA regulations.

5.4.3 Coordinates all planning, design, and construction activities for excavation projects with both the Environmental Compllance and Health Protection Division and the Office of Operational Safety. Informs appropriate health, safety, and environmental protection personnel of the upcoming projects, requests an ERDP environmental review and preparation of ERDP documentation for the profect, ensures that resulting documentation is properly endorsed and approved before construction is initlated, and ensures that the provisions for environmental protection given in the ERDP document are followed during the excavation phase of the project.

5.4.4 Ensures that a safety documentation is prepared in the form of a SS or SA as appropriate for each excavation project; ensures that all potential safety hazards are addressed, including those spectfic to individual sites; and ensures the inciusion of measures for controlling potential accident situations; ensures an analysis that includes the identification of potential radiological and chemical hazards that may be encountered at individual sites; and ensures that the SS or SA is properly endorsed, approved, and distributed before excavation operations are initiated.

* Other divisions that carry out excavation operations, such as Environmental Sciences Division, Plant and Equipment Diviston, or Engineoring Division, Will assume all the responstblitties given in Section 5.4 for Operations Division. However, if excavation is carried out by Operations Division for one of the above divistons, responstbility is retained by Operations Division. 
5.4.5 Ensures that a PWMP is generated for any project that will result in generated waste and that the plan is approved by the Operations Division.

5.4.6 Ensures that an excavation permit is processed and that a quality assurance review is performed and that a PQAA is prepared; ensures that the risks of potential significant quality problems (fallure modes) are identifled and evaluated; and ensures that activities given in the PQAA for prevention of problems are undertaken.

5.4.7 Ensures that each excavation location is properly classlfled (Table 1) by the IHD and RPD during review of the excavation/penetration permit: and ensures that coples of the firal approved permits are provided to the IHD, RPD, and to the EMCD prior to inftiating excavation activities.

5.4.8 Ensures that training is provided through the

Environmental Compliance and Health Protection Division for all crews (see Sections 5.1.15 alid 5.1.16).

5.4.9 Ensures that IHD and RPD staff receive prior notification of excavation activities and are present prior to initiation of activities in Category 2 and 3 areas.

5.4.10 Ensures that radiation monftoring instrumentation is provided to determine radlation levels in the work environment, to monitor the radiation levels of the generated waste, and to detect the presence of significant levels of radioactive contamination on tools, equipment, clothing, and personnel as defined in the ORNL Health Physics Procedure Manual.

5.4.11 Provides protective clothing and change and shower faclifties for work site personnel; ensures that protective clothing is properly used whenever required: arranges for appropriate segregation, packaging, labeling, and disposition of used protective clothing; and arranges for laundering at ORNL of all reusable protective clothing, when practicable.

5.4.12 Ensures that personnel at the work site are provided with radiation monitoring devices, that the monitors are worn correctiy, and the monitoring devices are returned for processing; ensures that excavating personnel are avallable for whole-body counting and urinalysis if warranted; and ensures that individuals suspected of having accidentaliy sustained an intake of radioactive materials are given a whole body count, and that urine specimens are taken as soon after an unusual occurrence as feasible. 
5.4.13 Ensures that personnel at the work site are provided with personal protective equipment, such as gloves, ear plugs or muffs, dust masks, resplrators, proper chemical cartridges, etc.; ensures that personnel using respirators are approved as respirator wearers by Industrial Hyglene; and ensures that protective equipment, if warranted, is properly used and that IHD or ISD personnel are consulted immediately if questions arlse concerning worker health and safety protection.

5.4.14 Ensures that excavating crew members and equipment undergo a contamination survey or evaluation for chemical contamination before leaving the excavation site if radioactive or chemlcal contamination is detected at any time during the excavating operation.

5.4.15 Arranges for handling, packaging and disposition of generated waste (soti, etc.) in accordance with the PWMP identified in Section 5.4.5.

5.4.16 Arranges for proper handling, packaging, and disposal of contaminated matertals, tools, and equipment; and, when feasible, arranges for containment, transport, and decontamination of contaminated tools and equipment.

5.4.17 Ensures that RPD approval is obtained before any radfologically contaminated materials, samples, tools, equipment, etc., are removed from the excavation site, and ensures that ali approved materials are properly identifled with radiation hazard tags before removal.

5.4.18. Ensures that the IHD and EMCD are notified as soon as feastbie if chemical contamination is encountered; ensures that injured individuals or those exposed to potantially hazardous chemicals are treated by the Health Division as soon as feasible; takes inmediate measures to prevent additional exposure or injury and takes immedlate measures for spill containment where applicable.

5.4.19 Provides proper equipment (e.g., barricades, ropes, signs, etc.) for appropriately designating zoned contamination areas.

5.4.20 Provides for sample collection and analyses, as necessary.

5.4.21 Ensures that appropriate sp 111 control and cleanup kits are avallable at the site for immedlate use. Except in cases where it is clearly unnecessary, the kit should include but not be restricted to oll absorbent pads, a catchment pan, a shovel, a working flashlight, and plastic sheeting or other impermeable sheeting material.

5.4.22 Initlates appropriate work permits or assures appropriate work permits are issued. 


\subsection{Engineering Division}

5.5.1 Authorizes the commencement of an excavation project by issuance of a Construction Excavation/Penetration permit; ensures that all the supplemental excavating criteria, such as location of all underground structures itid utilities have been fulfflled, and that it has been properly reviewed by Engtneering Diviston, Operations Division, Operational Safety, P\&E Division, EMCD, IHD and RPD personnel, and the operating supervisor. Revlews and approves ORNL P\&E Division Excavation/ Penetration Permits on request.

5.5.2 Ensures that SS or SA, PQAA, and PWMP requirements are in place prior to initiation of excavation work.

5.5.3 Ensures the inclusion of an excavation category (Table 1) in each Excavation/Penetration Permit and ensures the endorsement by IHD, EMCD and RPD representatives prior to issuance of the permit.

\subsection{PROCEDURES}

\subsection{Excavation-Classification Procedures}

6.1.1 Knowledgeable personnel from the Environmental Complitance and Health Protection Division (in collaboration with. Engineering Division. Operations Division personnel, and nearby facility operating personnel) will classify each excavation location according to the probability of encountering radioactive and/or chemical contamination at the site: The probability assigned (low, moderate, or high) will reflect the potential risk of exposure to personnel, the risk of release of contaminated materials to the environment, and the risk of contaminating equipment. When feasible, exploratory sub-surface sampling and investigations (such as augering and analyzing soil samples) will be carried out to assist in appropriately classifying suspect areas prior to initiating extensive excavation work. A given classification may be changed, if necessary, with proper approvals, to reflect variable contamination potential or actual contamination encountered at dffferent areas/locations or depths as the operation progresses. A reclassification can occur only after an evaluation is conducted to determine if work continuance at the location is warranted. If reclassification is granted, the evaiuation will be documented by the RPD and IHD representatives on the Excavation/Penetration Permit: if warranted, a revised permit will be issued. Excavation classification categories and associated protective measures are given in Table 1. 
6.1.2 Radlological classification will be used in all

excavation dectsions; a clear need for Category 2 and Category 3 excavations will be requited. Ciassification will be established during issuance of the Excavation/Penetration permits.

6.1.3 Excavation classiffcation will be a significant factor in siting decisions. Locations, which have a higher accident potential due to intersecting underground drains, pipas, tanks, conduits, etc., or overhead obstructions and hazards, should be avolded whenever posstble, especially for sites in Category 2 and 3.

6.1.4 Site classification will be a significant factor in planning and designing excavation projects; for example, placement of drili rigs on contaminated surfaces will be avolded and clean gravel or soll lay-down areas will be provided whenever feasible.

\subsection{ALARA Guidelines}

6.2.1 All excavating operations will follow ALARA guidelines regardiess of the classification: ALARA guidelines include measures to protect the environment as well as the health and safety of personnel and include dally inspection of excavation equipment to ensure that leaks of oil and/or other environmentally controlled substances are maintained ALARA. If warranted, spill control methods will be used to ensure that environmental releases are kept ALARA.

6.2.2 ORNL's EMCD and RPD representatives will be notified whenever radioactivity in soil or groundwater is encountered and levels are in excess of those given in Table D1. Appendix D. Any positive direct reading exceeding background should be reported for areas where the radiation reading exceeds the limits in Table Di.

6.2.3 ORNL'S IHD and EMCD representatives will be notified whenever chemical contamination in soil or groundwater is encountered. Immediate measures will be taken to control the environmental release of chemicals or oils and to prevent personnel exposure if significant concentrations of toxic materials are detected at the excavation site. Levels at or above the Threshold Limit Values (TLVs) or OSHA standards for specific chemicals

*Threshold Limit Vaives refer to airborne concentrations of substances and represent conditions under which it is believed that nearly all workers may be repeatedly exposed day after day without adverse effect (as defined in the most current edition of TLV booklet). 
are considered significant. Personnel experiencing symptoms that can be reasonably attributable to chemical exposure will be transported to the Health Division as soon as feasible for medical examination, and medical care if warranted.

6.2.4 Tools and equipment as well as generated waste will be checked for radioactivity before they are released for reuse or disposal; levels in excess of those given in Table DI. Appendix $D$, will be classified as contaminated.

6.2.5 Contamination zones will be established whenever radiological contamination levels exceed surface contamination limits given in Table D2. Appendix 0 . Personnel, materials, and equipment must be surveyed and must be free of loose contamination before leaving a contamination zone; contaminated equipment must either be decontaminated prior to leaving the zone or must be adequately contained (in plastic, wood crates, steel drums, etc.) and tagged prior to transport to another site. Contamination at a site should be cleaned up promptly, and the site should be dezoned as soon as practicable.

6.2.6 ORNL's RPD representative will be notified whenever there is evidence of personnel skin contamination or contamination of personal articles of clothing in excess of the values given in Tables $D 3$ and D4. Appendix $D$. Measures will be taken promptly to prevent the spread of contamination, and personnel and clothing will be decontaminated as soon as possible. Personnel decontamination beyond use of soap and water must be medicality supervised.

\subsection{Action Level Procedures}

6.3.1 In the event excavation waste is dry enough to produce airborne dust, measures will be taken to protect personnel from dust inhalation, and actions will be taken to suppress the dust with moisture as materials are removed from the excavation site. Evaluation of the situation will be made by ORNL's RPD, IHD, and EMCD rapresertatives or the Operating Supervisor.

6.3.2 When levels of airborne contaminants that significantiy exceed background are detected, additional actions musi be taken to identify and quantify specific contaminants and to implement appropriate control measures.

6.3.3 Excavation will be halted by the project manager, field representative or his/her designee and ORNL's RPD representative will be notified when soil contamination 
direct reading levels exceed $5 \mathrm{mrad} / \mathrm{h}$ or 6000 alpha $\mathrm{dpm} / 100 \mathrm{~cm}^{2}$. The ORNL RPD representative will assist operations Division and Engineering Division personnel in evaluating the situation to determine whether operations should be continued, whether additional containment or protective clothing is required, or whether the excavation work should be discontinued; factors to be considered will include the location of the site, the waste contamination levels, the weather conditions, and the abllity to effect positive control over contaminated material and equipment.

6.3.4 Excavation will be halted by the project manager, field representative or his/her designee in the event of adverse weather conditions, in which encountered contamination (radiological or other hazardous substance) may be dispersed to the environment or may go undetected; excavation activities may be resumed by the operating supervisor when weather conditions improve.

6.3.5 Excavation will be halted by the project manager, field representative or his/her. designee in the event that the viscosity of generated waste becomes too low to ensure complete containment or if transfer of the waste to drums cannot be accnmplished without loss of material to the environment; excavation may be resumed when the situation is corrected as determined by ORNL's RPD, IHD, and EMCD representatives or the Operating Supervisor.

6.3.6 Excavation will be halted by the project manager, field representative, or his/her designee, in the event of any containment failure that could resuit in significant contamination of personnel, equipment, or the environment: excavation may be resumed when the situation is corrected as determined by ORNL'S RPD, IHD, and/Or EMCD representatives.

6.3.7 Excavation will be halted by the project manager, field representative or his/her designee in the event that waste is contaminated with radioactivity in excess of $100 \mathrm{mrad} / \mathrm{h}$ or 30,000 alpha $\mathrm{dpm} / 100 \mathrm{~cm}^{2}$; approval by the Environmental Compliance and Health Protection Division and Office of Operational Safety will be required to resume operations.

6.3.8 Excavation will be halted by the project manager, field representative or his/her designee in the event that a subsurface obstruction is encountered; excavation will not be resumed until the obstruction is evaluated and permission is granted through the excavation permit by the Environmental Compliance and Health Protection and Engineering Divisions. 
6.3.9 Excavation will be haited in the event that excavation uncovers an emplacement of buried chemicals, penetrates a buried gas cylinder, or otherwise encounters potentially toxic materials; ORNL's IHD and EMCD will be notified and excavation will not be resumed until the situation is evaluated and permission is granted in writing by Industrial Hygiene Department management.

\subsection{Radiation Work Permit Procedures}

6.4.1 Radiation Work Permits will be issued where actual or anticipated contamination/radiation levels meet or exceed permit requirements given in Appendix $C$ and the Health Physics Procedures Manual Procedure 2.6. Permits will be approved only after verification that all members of the excavating crew have completed Category 3 Training or approved equivalent.

\subsection{Waste Handling and Disposal Procedures}

6.5.1 All types of wastes generated during excavating will be handled in a manner that restricts dispersion into the environment; this inciudes but is not restricted to dusts, liquids, solids, drilling muds, well-drilling cuttings, etc.. All types of materials will be checked for radioactivity. A containment system that restricts the release of the wastes to the environment will be provided for all waste materials. radioactive, chemically hazardous, and environmentaliy controlled (e.g. oil, grease, gasoline) as well as nonradioactive and nonhazardous, throughout excavating operations; and measures will be taken for erosion contrnl of non-waste soils.

6.5.2 Retention of wastes at the excavation site will be minimized; those wastes temporarily retained will be protected to prevent dispersion into the environment as approved by EMCD. Events such as adverse weather conditions or accidental human or animal entry onto the site will be anticipated in planning for environmental and personnel protection.

6.5.3 Soil generated from excavating activities shall be managed in accordance with procedures contained in the ORNL Environmental Protection Manual, the Operations Division Waste Management Procedures, the Health Physics Manual and in accordance with criteria in Appendix $B$ of this procedure.

6.5.4 Wastes containing hazardous, toxic, or environmentally controlled materials will be transferred to the Operations Division's Waste Management Section for 
proper packaging and transportation to an off-site disposal facility if warranted; mixed (radioactive and hazardous) wastes will be transferred to an on-site (RCRA-permitted) mixed waste storage facility.

6.5 .5

Water and mud resulting from excavating operations

(e.g., material collected in the discharge containment system used for air/water rotary drilling of Category 2 and 3 wells) may be disposed of as uncontaminated waste, provided: (a) direct readings near contact with excavation cuttings and equipment and near contact with cuttings, cuttings containers, and drill equipment do not exceed $0.05 \mathrm{mrad} / \mathrm{h}$ beta/gamma or 300 alpha $\mathrm{dpm} / 100$ $\mathrm{cm}^{2}$ and (b) smear readings from equipment used in excavating do not exceed 200 beta/gamma dpm/100 $\mathrm{cm}^{2}$ or 20 alpha $\mathrm{dpm} / 100 \mathrm{~cm}^{2}$. If contamination was detected during augering in soil, but no contamination exceeding levels in (a) and (b) were encountered during air/water rotary drilling, disposition of water and mud waste will be based on laboratory analyses of representative samples of the sediment and water collected in the containment system. Mud and water with radioactivity levels greater than or equal to $20 \mathrm{alpha} \mathrm{dpm} / \mathrm{g}$ or greater than or equal to $278 \mathrm{beta} / \mathrm{gamma} \mathrm{dpm} / \mathrm{g}$ will be disposed of as contaminated waste, following approved procedures.

6.5.6 No departure from the waste handling and disposal procedures will be allowed unless approval in writing is granted by the Operations Division and Environmental Compliance and Health Protection Division Management. 
APPENDIX A

\section{CATEGORY 3 EXCAVATION TRAINING}


HEALTH AND ENVIRONMENTAL TRAINING PROGRAM FOR

EXCAVATION WORKERS IN CATEGORY 3 AREAS

\section{Basis for Training Requirement}

Department of Energy regulations hold ORNL responsible for ensuring that all persons entering the ORNL site operate according to all environmental, health, and safety procedures related to their work on site. Therefore, environmental, health, and safety training programs have been established for all individuals working on the ORNL site, including contract construction workers and managers.

\section{Training Program Assumptions}

The level of training for this application has been determined based on the following assumptions: (1) one radiation protection technician will be assigned by the RPD to provide full time survelliance for each excavating crew, (2) the subcontractor workers and craw foremen have attended ORNL's Basic Health and Environmental Training for Off-Site Contractors, (3) all participants have attended the Industrial Hygiene respirator fitting and training program and hold a current card documenting that fact, and (4) participants chosen by their company are capable of meeting the minimum training requirements established by ORNL.

\section{Training Program Elements}

The training program will contain the following modules:

- Biological Effects of Radiation

- Risks Associated with Exposure to Radiation

- Personnel Monitoring Techniques

- Correct Procedures for Donning and Safely Removing Protective Clothing

- Review of Proper Use of Respiratory Protection Equipment

- Contamination Control Management and Techniques (including Decontamination)

\section{Training Program Testing Requirements}

A written examination will be given at the end of the formal training program. Tested individuals will be required to correctly answer a minimum of $70 \%$ of the test questions. Performance-based testing will also be conducted for all individuals in the training program. Each individual will be required to correctly perform the following exercises: (1) demonstrate correct steps to don and remove protective clothing; (2) demonstrate knowledge of proper procedures to follow when working in a contamination area; and (3) demonstrate knowledge of correct decontamination procedures for equipment, clothing, and themselves. 
Each individual will have two opportunities to successfully complete the written examination and the performance-based examination phases. If an individual has not successfully completed both parts of the examination after two attempts at each, the individual will not be permitted to perform work in a Category 3 area.

Thls training will be conducted by two or more technical trainers/professional staff members of the Environmental Compliance and Health Protection Division. Participation in this training program will be limited to ONE excavating crew and ONE backup crew. Retraining will be providad every two years.

\section{Training Program Record Keeping Requirements}

Written documentation will be maintained by the Technical Resources and Training Program, Environmental Compliance and Health Protection Division. The original written examination and checklist from the performance-based examination will be kept on file for all individuals tested (both successful and unsuccessfui). This documentation will be provided to the contracting company upon written request. 
APPENDIX B

RADIOLOGICAL SOIL HANDLING CRITERIA, FLOWCHART, and BASIS 
Appendix B - Radiological Soll Handling Criterla

Category 1 - This soll has unrestricted use on the Oak Ridge Reservation. Direct measurements taken at the surface of the soll are less than $300 \mathrm{dpm} / 100 \mathrm{~cm}^{2}$ alpha and less than $0.02 \mathrm{mrad} / \mathrm{h}$ beta/gamma. Smear counts from equipment tilat contacted the soll are less than 20 $\mathrm{dpm} / 100 \mathrm{~cm}^{2}$ alpha and less than $200 \mathrm{dpm} / 100 \mathrm{~cm}^{2}$ beta/gamma. If there is historlcal evidence of alpha or low-energy deta contamination, the soll should be analyzed in the laboratory.

If laboratory analyses indicate alpha activity greater than $0.33 \mathrm{~Bq} / \mathrm{g}$ or beta/gamma activity greater than $1.8 \mathrm{~Bq} / \mathrm{g}$, the soll may not be used in an unrestricted manner but must be considered "contaminated" soll.

Category 2 Soll in this category may be used for 11 mited backfliling. Measurements at the surface of this soll are equal to or greater than 300 and less than 6000 $\mathrm{dpm} / 100 \mathrm{~cm}^{2}$ alpha and equal to or greater than 0.02 and less than $5.0 \mathrm{mrad} / \mathrm{h}$ beta/gamma. If laboratory analyses have been conductod, soll having alpha activities less than $0.75 \mathrm{~Bq} / \mathrm{g}$ and beta-gamma activities less than $450 \mathrm{~Bq} / \mathrm{g}$ may be used for limited backfliling.

Soll in this category may be used for backflli at the site of origin or in a contaminated zone of simllar radiation levels. provided that the area to be backfilled is not intended for continuous human occupation. In each location where Category 2 soll is used as backfill, at least one foot of clean uncontaminated soll must be placed over the contaminated backfill, and the site must be identified as a maintained area and marked on maps that are kept updated. In no case should contaminated soll be used as backfill in uncontaminated areas.

Soll not needed for backflll shall be considered as radwaste (Category 3 ) and sent, after proper packaging, to the designated SWSA.

Category 3 Soll in this category may not be used for backflll but w111, be considered as radwaste and sent to the designated SWSA. Surface readings are equal to or greater than $6000 \mathrm{dpm} / 100 \mathrm{~cm}^{2}$ alpha and equal to or greater than $5.0 \mathrm{mrad} / \mathrm{h}$ beta/gamma. If soll has been analyzed in the laboratory, activities equal to or greater than $0.75 \mathrm{~Bq} / \mathrm{g}$ alpha and equal to or greater than $450 \mathrm{~Bq} / \mathrm{g}$ beta/gamma indicates the soll qualifies as radwaste. 


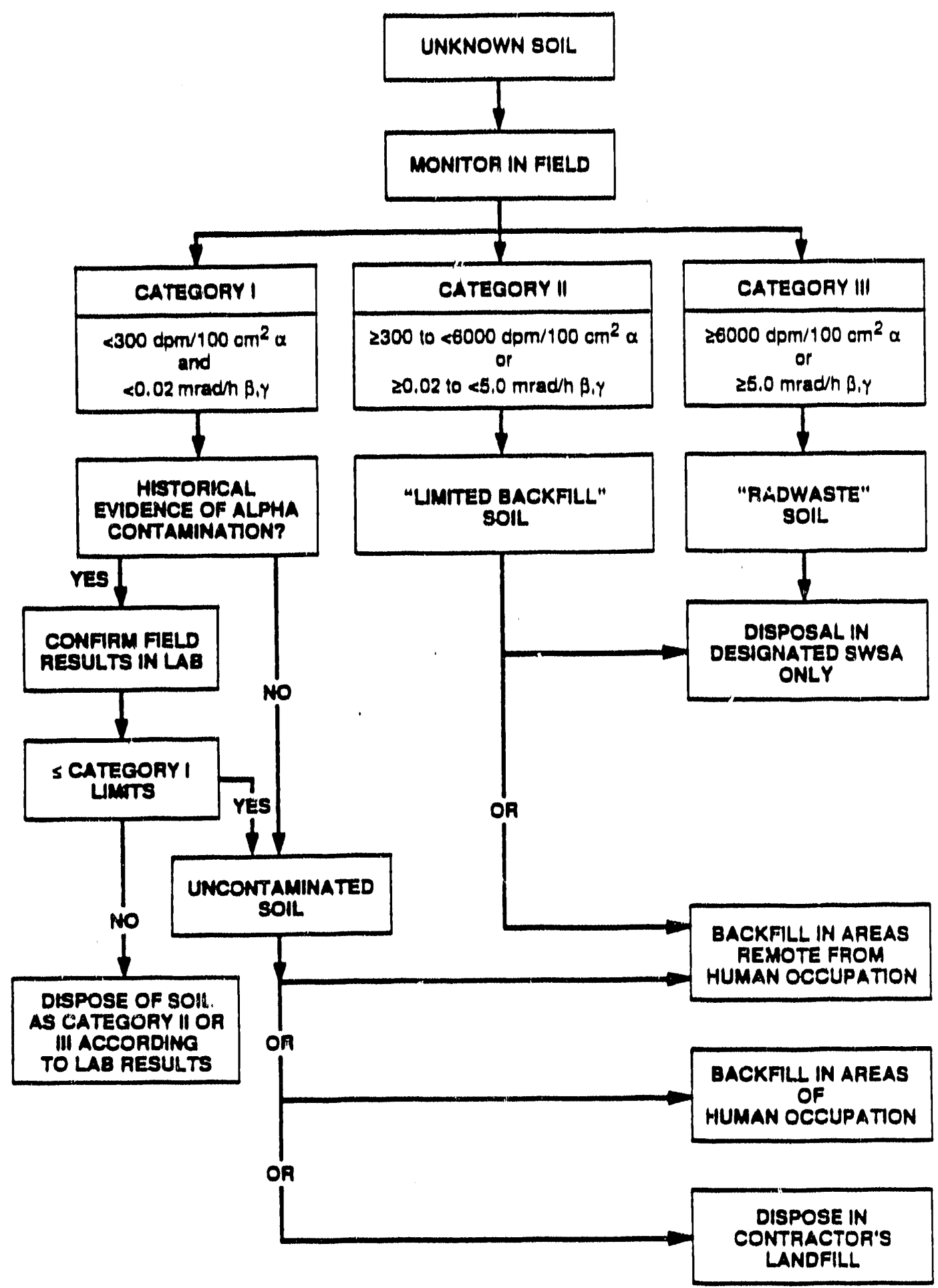

APPENDIX B - FLOWCHART FOR HANDLING POTENTIAL RADIOLOGICALLY CONTAMINATED SOIL 
Basis for Radiological Soll Handilng Criterla

These soll handling criterla were developed to provide a safe and practlcal methodology for dealing with contaminated soll in the fleld. Radlological characteristles for Category i soll are based on current "green tag" 11 mits. Radiological characteristics for Category 2 soll are based on an exposure rate reduction factor of 100 through use of at least one foot of uncontaminated backfl11. Category 2 soll should not be used as backflli in areas where continuous human habltition is anticlpated.

These criterla define radiological limits which are measurable with field instrumentation and provide an acceptable level of radtation safety for workers and persons exposed to this soll when used as backflll. THESE CRITERIA ARE INTENDED ONLY FOR SOILS LOCATED ON AND REMAINING ON THE OAK RIDGE RESERVATION WHERE INSTITUTIONAL CONTROL IS IN PLACE. 
APPENDIX C

RADIATION WORK PERMIT CRITERIA 
CRITERIA FOR ISSUING RADIATION WORK PERMITS

The expected dose is greater than $20 \mathrm{mrem}$ to the whole body or 300 mrem to extremities for an individual durting a single work shift, or

the afrborne radioactivity is greater than the Haximum Permisstbie Concentration (MPC)a for a 40-hour week (respirators required), or

the work involves expc sure of an individual to a dose rate greater than $5 \mathrm{rem} / \mathrm{h}$ to the total body. 
APPENDIX D

RADIOLOGICAL CONTAMINATION CRITERIA 
Table DI. Recommended action level contamination guide

\begin{tabular}{|c|c|c|c|}
\hline \multicolumn{2}{|c|}{ Direct Reading } & \multicolumn{2}{|c|}{ Transferable Smear } \\
\hline $\begin{array}{l}\text { Alpha } \\
\left(\mathrm{dpm} / 100 \mathrm{~cm}^{2}\right)\end{array}$ & $\begin{array}{l}\text { Beta/Gamma } \\
(\mathrm{mrad} / \mathrm{h})\end{array}$ & $\begin{array}{c}\text { Alpha } \\
\left(\mathrm{dpm} / 100 \mathrm{~cm}^{2}\right)\end{array}$ & $\begin{array}{c}\text { Beta/Gamma } \\
\left(\mathrm{dpm} / 100 \mathrm{~cm}^{2}\right)\end{array}$ \\
\hline 300 & 0.05 & 20 & 200 \\
\hline
\end{tabular}


Table D2. Guide for establishing contamination zones

\begin{tabular}{cccc} 
Surface Contamination \\
\hline $\begin{array}{c}\text { Alpha } \\
\left(\mathrm{dpm} / 100 \mathrm{~cm}^{2}\right)\end{array}$ & $\begin{array}{c}\text { Beta/Gamma } \\
(\mathrm{mrad} / \mathrm{h})\end{array}$ & $\begin{array}{c}\text { Alpha } \\
\left(\mathrm{dpm} / 100 \mathrm{~cm}{ }^{2}\right)\end{array}$ & $\begin{array}{c}\text { Beta/Gamma } \\
\left(\mathrm{dpm} / 100 \mathrm{~cm}^{2}\right)\end{array}$ \\
\hline 300 & 0.25 & 30 & 1000 \\
\hline
\end{tabular}


Table 03. Recommended maximum contamination guide for skin surface

\begin{tabular}{|c|c|c|c|}
\hline & \multicolumn{2}{|c|}{ Direct Reading } & Iransferable Smear \\
\hline & $\begin{array}{c}\text { Alpha } \\
\left(\mathrm{dpm} / 100 \mathrm{~cm}^{2}\right)\end{array}$ & $\begin{array}{l}\text { Beta/Ganma } \\
(\mathrm{mrad} / \mathrm{h})\end{array}$ & $\begin{array}{cc}\text { Alpha } & \text { Beta/Gamma } \\
\left(\mathrm{dpm} / 100 \mathrm{~cm}^{2}\right)\left(\mathrm{dpm} / 100 \mathrm{~cm}^{2}\right)\end{array}$ \\
\hline \multirow[t]{2}{*}{ General Body } & 150 & 0.05 & \\
\hline & & & None detectable \\
\hline Hands & 300 & 0.2 & \\
\hline
\end{tabular}

- Detection limit is related to the instrumentation used. 
Table DA. Recommended maximum* contamination guide for shoes and clothing

\begin{tabular}{|c|c|c|c|c|}
\hline & \multicolumn{2}{|c|}{ - Direct Reading } & \multicolumn{2}{|c|}{ Transferable Smear } \\
\hline & $\begin{array}{c}\text { Alpha } \\
\left(0 \mathrm{pm} / 100 \mathrm{~cm}^{2}\right)\end{array}$ & $\begin{array}{c}\text { Beta/Gamma } \\
(\mathrm{mrad} / \mathrm{h})\end{array}$ & $\begin{array}{c}\text { Alpha } \\
\left(\mathrm{dpm} / 100 \mathrm{~cm}^{2}\right)\end{array}$ & $\begin{array}{c}\text { Beta/Gamma } \\
\left(\mathrm{dpm} / 100 \mathrm{~cm}^{2}\right)\end{array}$ \\
\hline Shoes, contamination zone & 300 & 2.5 & 20 & 1000 \\
\hline Shoes, personal & 300 & 0.3 & 20 & $1000 * *$ \\
\hline Clothing, contamination zone & 300 & 0.75 & \multicolumn{2}{|c|}{ Not applicable } \\
\hline $\begin{array}{l}\text { Clothing, other company- } \\
\text { issued, and personal }\end{array}$ & 150 & 0.25 & \multicolumn{2}{|c|}{ Not applicable } \\
\hline
\end{tabular}

* No $100 \mathrm{~cm}^{2}$ area to average greater than this vaicue.

- Except $126 \mathrm{I}, 131_{\mathrm{I}}$, and $133 \mathrm{I}$ for which the guide is $200 \mathrm{dpm} / 100 \mathrm{~cm}^{2}$ and $125_{I}, 129_{I}$, and $227_{A c}$ for which the guide is $20 \mathrm{dpm} / 100 \mathrm{~cm}^{2}$. 


\section{REVISION/REVIEW STATUS SHEET}

\begin{tabular}{|c|c|c|c|}
\hline $\begin{array}{l}\text { Revision } \\
\text { Number }\end{array}$ & $\begin{array}{l}\text { Revision/ } \\
\text { Review } \\
\text { Date }\end{array}$ & $\begin{array}{l}\text { Responsible } \\
\text { Signature }\end{array}$ & Action Taken \\
\hline & & & \\
\hline & & & \\
\hline & & & \\
\hline & & & \\
\hline & & & \\
\hline & & & \\
\hline & & & \\
\hline & & & \\
\hline & & & \\
\hline & & & \\
\hline & & & \\
\hline & & & \\
\hline & & & \\
\hline & & & \\
\hline & & & \\
\hline & & & \\
\hline & & & \\
\hline & & & \\
\hline & & & \\
\hline & & & \\
\hline & & & \\
\hline
\end{tabular}


Distribution:

Alexander, J. F.

Baldwin, M. E.

Bates, L. D.

Bogard, J. S.

Braunstein, H. M.

Brown, J.S.

Butler, H. M.

Canon, R. M.

Clark, C.

Collins, E. D.

Cook, K. W.

Copenhaver, E. D.

Doyle, G. M.

Dumont, S. P.

Durfee, N. W.

Eads, B. G.

Ferguson, $W$. $F$.

Ferris, L. M.

Fox, C. L.

Fulkerson, $W$.

Gaddis, H. R.

Garren, C. L.

Garrett, R. S.

Gray, D. H.

Greene, J. H.

Hamblen, S. E.

Horton, J. R.

Hyde, L. D.

Kendrick, C. M.

Krieg, E. H.

Lankford, B. R.

Lawson, J. R.

Manrod, W. E.

McConathy, R. K.

McNeese, L. E.

Melroy, P. E.

Merriman, J. R.

Mezga, L. J.

Miller, C. H.

Miller, D. R.

Mitcheil, M. E.

Morrison, J. M.

Myrick, T. E.

Norris, D. R.

Ohnesorge, $W$. $F$.

Oliphant, G. W.

Parzyck, D. C.

Patton, F. S.

Piper, H. B.

Rorter, W. E.

Reichle, D. E.

Rogers, J. G.

Rohwer, P. S.

Row, T. H.

Scanlan, T. F.

Shaner, D. G.

Sherrod, J. D.

Smith, W. T.

Swanks, J. H.

Kuykendall, W. C.

Walls, D. M.

Walsh, P. J.

Witshire, R. S. 


\section{INTERNAL DISTRIBUTION}

\author{
1. L.D. Bates \\ 2. W.J. Boegly \\ 3. H.M. Braunstein \\ 4. C. Clark \\ 5. J.B. Clendenen \\ 6. K.W. Cook \\ 7. J.N. DuMont \\ 8.9. L. D. Hyde \\ 10. T.E. Myrick
}

11. C.E. Nix

12. P.S. Ogle

13. P.T. Owen

14. J.D. Sherrod

15. C.L. Stair

16. I.D. Voorhees

17. Laboratory Records, RC 18-22. RI/FS Document Control.

\section{EXTERNAL DISTRIBOTION}

23. T.W. Joseph, U.S. Department of Energy, Oak Ridge Operations office, P.O. Box 2001, ERB, G-105, Oak Ridge, TN 37831

24. T.J. Wheeler, U.S. Department of Energy, Oak Ridge Operations office, P.O. BOX 2001, FOB, ER-121, Oak Ridge, TN 37831

*25-35. T.J. Wheeler, U.S. Department of Energy, Oak Ridge Operations office, P.O. BOX 2001, FOB, ER-121, Oak Ridge, TN 37831

36-37. OFFICE OF Scientific and Technical Information;

P.O. Box 62 OAK RIDGE TENNESSEE 37831

* Uncontrolled copies 

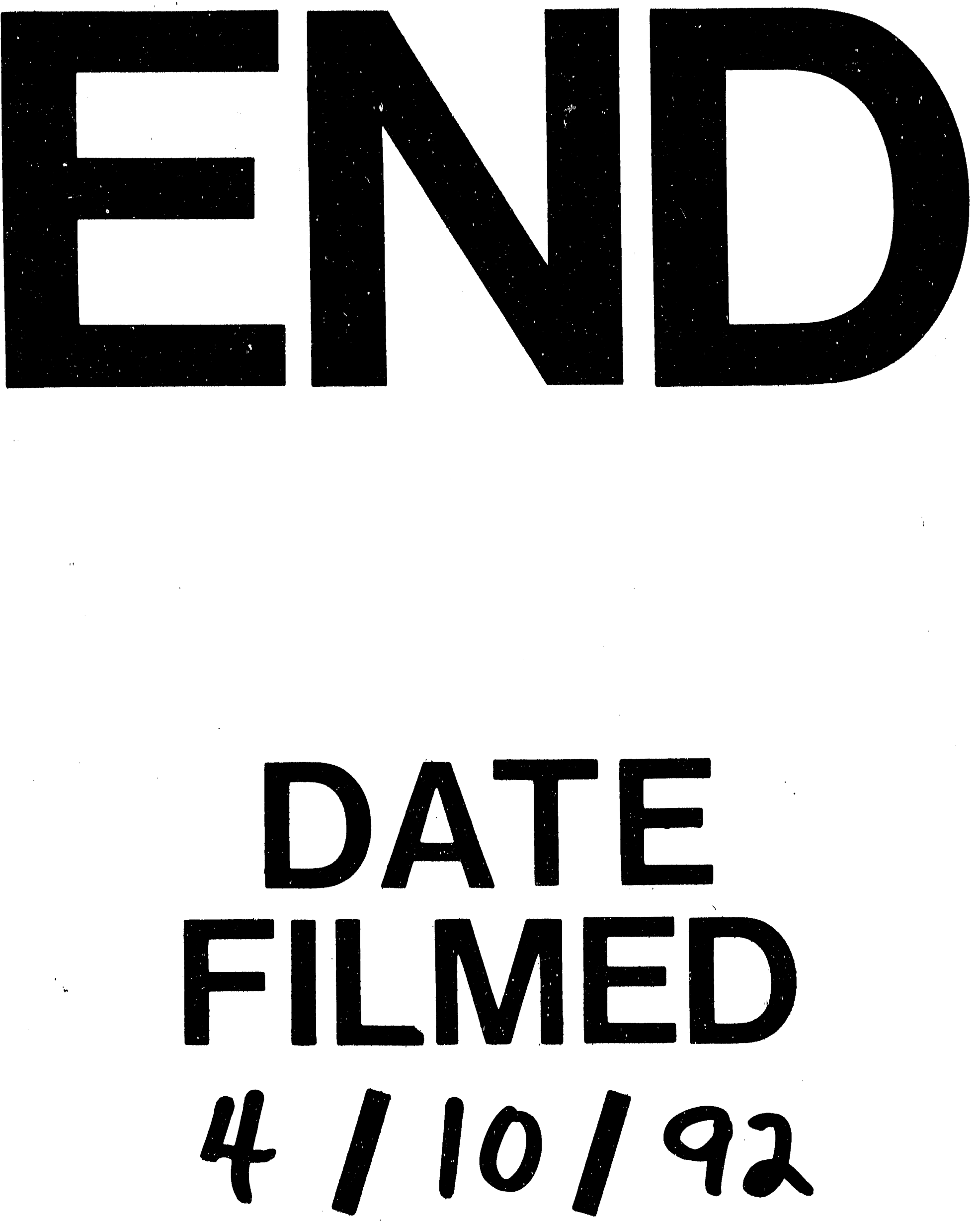

I 
